NISTIR 5273

\title{
Smoke Plume Trajectory from In Situ Burning of Crude Oil in Alaska
}

Kevin B. McGrattan Anthony D. Putorti William H. Twilley

David D. Evans

$-\mathrm{OC}$ 100

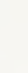





\section{Smoke Plume Trajectory from In Situ Burning of Crude Oil in Alaska}

Kevin B. McGrattan

Anthony D. Putorti

William H. Twilley

David D. Evans
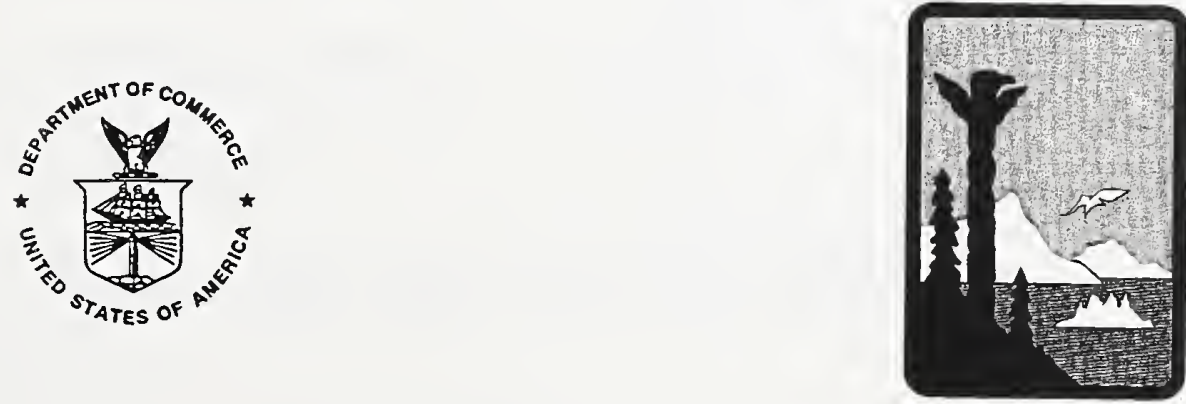

U.S. Department of Commerce

Ronald H. Brown, Secretary

National Institute of Standards and Technology Arati Prabhakar, Director

Prepared for the

Alaska Department of

Environmental Conservation

Division of Spill Prevention and Response 



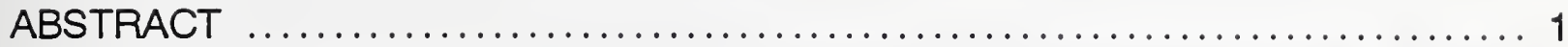

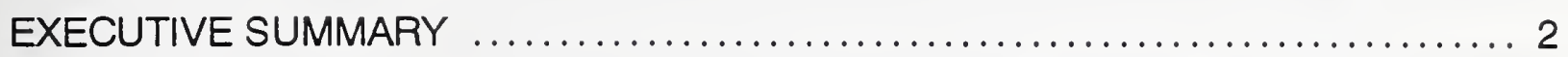

PART 1: EXPERIMENT AND ANALYSIS $\ldots \ldots \ldots \ldots \ldots \ldots \ldots \ldots \ldots \ldots \ldots$

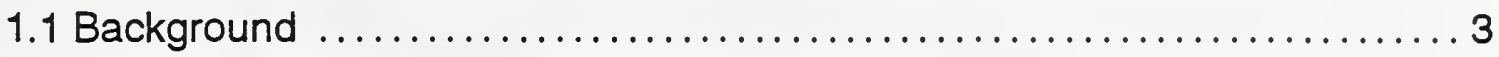

1.2 Experimental Apparatus .....................................

1.3 Crude Oil Analysis . .......................................... 4

1.4 Qualitative Burning Characteristics ............................. 4

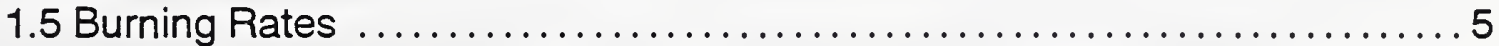

1.6 Smoke Yield ............................................ 8

1.7 Particle Size Distribution .................................... 9

PART 2: DETERMINATION OF SMOKE PLUME CALCULATION INPUTS $\ldots \ldots \ldots 16$

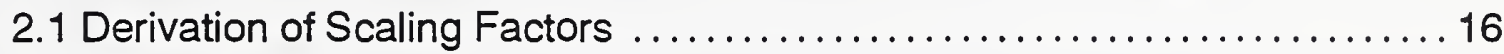

2.2 Plume Model Inputs ..................................... 19

PART 3: SMOKE PLUME TRAJECTORY MODELING $\ldots \ldots \ldots \ldots \ldots \ldots \ldots \ldots 22$

3.1 Mathematical Model .........................................22

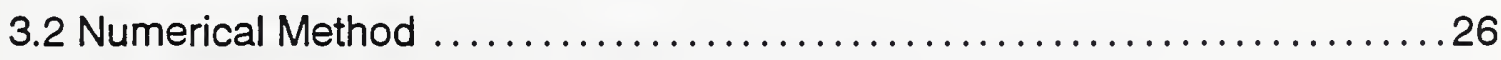

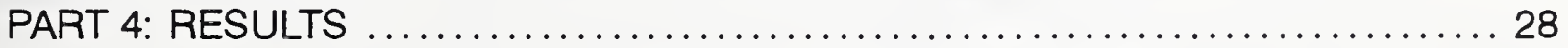

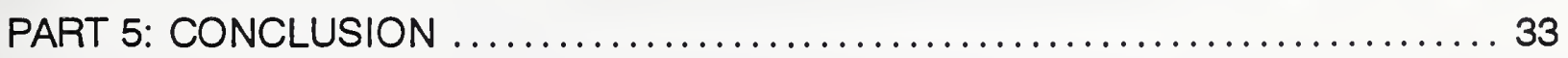

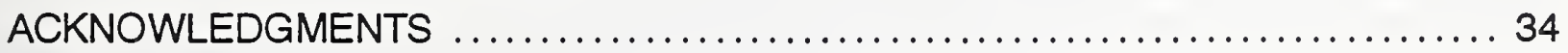

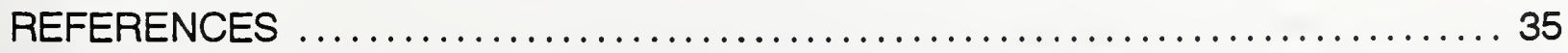

APPENDIX: LES PLUME TRAJECTORY MODEL RESULTS ................. 37 


\section{LIST OF FIGURES}

Figure 1. Heat release rate for North Slope crude oil burns

Figure 2. Heat release rate for Cook Inlet crude oil burns .7

Figure 3. Smoke aerosol size distribution for North Slope crude oil burns using the high flow rate impactor

Figure 4. Smoke aerosol size distribution for Cook Inlet crude oil burns using the high flow rate impactor

Figure 5. Smoke aerosol size distribution for North Slope crude oil burns using the personal impactor

Figure 6. Smoke aerosol size distribution for Cook Inlet crude oil burns using the personal impactor

Figure 7. Louisiana crude oil surface regression rate. Previous and new data.

Figure 8. Louisiana crude oil smoke yield. Previous and new data 18

Figure 9. Smoke aerosol size distribution for Louisiana crude oil using the personal impactor

Figure 10. Three dimensional view of a computed smoke plume in the first few kilometers of its development...

Figure 11. View of the smoke plume from underneath

Figure 12. Sample results for a typical LES Model run.

Cook Inlet crude oil is burned in the vicinity of the Cook Inlet

Figure 13. Sample results for a typical LES Model run.

North Slope crude oil is burned in the vicinity of the Cook Inlet

Figures 14-41. LES Model results 38-65 


\section{LIST OF TABLES}

Table 1. Elemental analysis of crude oils 4

Table 2. Crude oil properties .5

Table 3. Average burning rate and heat release rate, steady burning phase $\ldots \ldots \ldots .8$

Table 4. Average smoke yield, steady burning phase $\ldots \ldots \ldots \ldots \ldots \ldots \ldots \ldots \ldots$

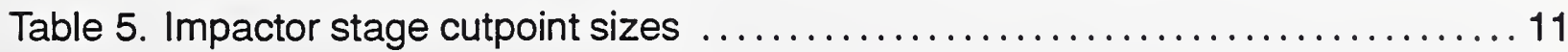

Table 6. Estimated large scale burning rate, heat release rate, and smoke yield ..... 16

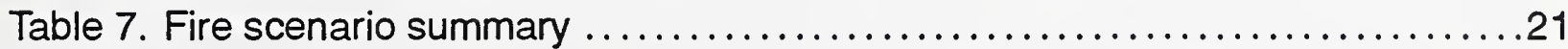

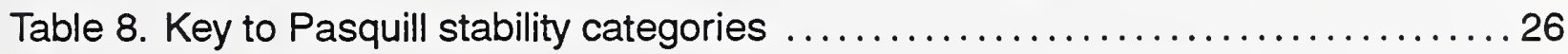

Table 9. Summary of LES smoke plume trajectory model runs $\ldots \ldots \ldots \ldots \ldots \ldots$. 32 



\title{
Smoke Plume Trajectory from In Situ Burning of Crude Oil in Alaska
}

\author{
K.B. McGrattan, A.D. Putorti, W.H. Twilley, D.D. Evans \\ Building and Fire Research Laboratory \\ National Institute of Standards and Technology \\ U.S. Department of Commerce \\ Gaithersburg, MD 20899
}

\begin{abstract}
Experimentation, analysis, and modeling have been performed to predict the downwind dispersion of smoke resulting from in situ burning of oil spills. North Slope and Cook Inlet crude oils are burned on water in a 1.2 meter diameter pan. Smoke yields were found to be $11.6 \% \pm 1.0$ for North Slope crude, and $9.2 \% \pm 0.6$ for Cook Inlet crude by mass of fuel consumed, with a $95 \%$ confidence interval. Burning rates and smoke aerosol size distributions are also measured, and found similar to previous work with different crude oils. Derivation of scaling factors for predicting the burning rates and smoke yields of large scale fires are guided by previous experiments with Louisiana crude oil. Scaled burning rates and smoke yields are supplied as input parameters for the LES (Large Eddy Simulation) model, version 2.0, of windblown smoke transport over flat terrain. For weather conditions appropriate for the Cook Inlet and North Slope areas, model results are presented which predict downwind dispersion and ground level concentrations of the fire generated particulate matter. The model predicts that ground level particulate concentrations in excess of $150 \mu \mathrm{g} / \mathrm{m}^{3}$ are limited to strips $5 \mathrm{~km}$ long and $1 \mathrm{~km}$ wide downwind of the fire for all meteorological conditions considered.
\end{abstract}

Key words: crude oil; oilspills; pool fires; smoke; fire plumes 


\section{EXECUTIVE SUMMARY}

A principal concern in the decision to use in situ burning as an oil spill mitigation technique is the anticipated trajectory of the smoke plume and the dispersion of the particulate matter generated by the fire. In this report we describe the Large Eddy Simulation (LES) model of smoke transport, version 2.0, which may be used to predict the concentration of combustion products downwind of the fire. Experiments have been conducted to determine the heat release rate and smoke yield from two types of Alaskan crude oils, North Slope and Cook Inlet, burning in a 1.2 meter diameter pan. Based on results from mesoscale experiments performed in a 15 meter square pan at the US Coast Guard mesoscale burn facility in Mobile Bay, Alabama, the laboratory results for the Alaskan crude oils are extrapolated to mesoscale to be used as input for the LES plume trajectory model.

The mathematical model consists of solving the conservation equations of mass, momentum and energy which describe the steady-state, convective transport of heated gases introduced into the atmosphere by a continuously burning fire and blown by a uniform ambient wind. We do not model the fire itself, but rather the plume of smoke which emanates from it. Only the convective heat release rate and smoke yield per unit area of burning surface are required from experiments. Then, as input to the model, one need only specify the area of burning surface, the wind speed and its fluctuations, and the temperature stratification of the atmosphere. We consider two burn areas, 232 and $465 \mathrm{~m}^{2}$ (2500 and $5000 \mathrm{ft}^{2}$ ), which are roughly semi-circular and contained in the apex of a boom. It is estimated that burns covering these areas will consume about 13,000 and 27,000 gallons of oil per hour and generate 500 and 1,000 megawatts of heat, respectively. For the Cook Inlet crude, about $9 \%$ of the mass of fuel consumed will be converted into particulate matter; for the North Slope crude, roughly $12 \%$. Wind speeds in the range from about 5 to 25 knots are considered. The temperature profiles used in the calculations correspond to typical summer and winter conditions of the Cook Inlet and North Slope regions.

In processing the results of the model, special attention was given to the downwind and lateral extent of ground level particulate concentrations in excess of $150 \mu \mathrm{g} / \mathrm{m}^{3}$ averaged over one hour. Although there is no formal guidance available about safe levels of particulate from oil fires, $150 \mu \mathrm{g} / \mathrm{m}^{3}$ averaged over 24 hours is the upper level established under air quality control regulations in Alaska [13]. For the range of parameters discussed above, the calculations show that particulate concentrations found at the ground downwind of oil spill burns will not exceed $150 \mu \mathrm{g} / \mathrm{m}^{3}$ beyond $5 \mathrm{~km}$, nor outside of a strip approximately $1 \mathrm{~km}$ wide along the centerline of the plume trajectory. Given the assumptions and uncertainties inherent in the model, it is reasonable to assign a factor of safety of 2 to these distances. This is especially prudent since the model does not at the moment consider terrain effects or coastal weather conditions which could possibly lead to higher ground level concentrations than those predicted by the model. 


\section{PART 1: EXPERIMENT AND ANALYSIS}

\subsection{Background}

This study is part of a continuing effort at NIST aimed at understanding and evaluating in situ burning as a marine oil spill response tool. Extensive studies of crude oil layers burning on water have been conducted at various scales ranging from 0.085 meters to 17.2 meters in diameter, with several different crude oils $[1,2]$. During previous studies, however, burns greater than 2.0 meters in diameter have been conducted exclusively with Louisiana crude oil. Since full scale data is not available for Cook Inlet and North Slope crude oil burns, we assume that the behavior of these crude oils is similar to that of Louisiana crude oil, which at this time is the only oil studied extensively at a large range of fire sizes.

In order to model the burning and smoke plume formation resulting from the use of in situ burning, it is important to know the burning rate of the fuel. The burning rates of fires of different scales may be compared if the burning rate of fuel is expressed as the mass loss rate per unit area of fuel surface, ie. $\mathrm{kg} /\left(\mathrm{s} \cdot \mathrm{m}^{2}\right)$. The regression rate of the fuel surface is also useful for comparison purposes, and is related to the burning rate per unit area via oil density.

The fraction of fuel mass consumed by the fire that is emitted as smoke aerosol, defined as smoke yield, is another parameter necessary for the modeling of smoke plumes. In this investigation, the terms smoke aerosol, smoke, and smoke particulate are all synonymous and are defined as the condensed phase components of the combustion products [3].

Uncertainties stated in this report represent a 95\% confidence interval $[4,5]$.

\subsection{Experimental Apparatus}

The experimental series was conducted at NIST's large scale fire experimentation facility. A steel pan measuring 1.2 meters in diameter and 0.30 meters deep was placed under the large calorimeter hood. The bottom of the pan is equipped with a pressure transducer used to monitor the mass of oil and water in the pan. At the start of each burn, a $25 \pm 4 \mathrm{~mm}$ thick layer of oil was added on top of $245 \pm 4 \mathrm{~mm}$ of water, placing the top surface of the oil approximately $30 \mathrm{~mm}$ from the lip of the pan. The experimental series consisted of 1 Louisiana, 5 North Slope, and 4 Cook Inlet crude oil burns.

The calorimeter is equipped for oxygen depletion calorimetry, which is based on the principle that most burning materials emit $13.1 \mathrm{MJ}$ of heat per $\mathrm{kg}$ of oxygen consumed. [6] The mass of oxygen consumed is derived from the decrease in oxygen concentration in the combustion products flowing through the exhaust stack as compared to ambient air. The drop in oxygen concentration is multiplied by the volume flow rate of exhaust gases through the stack, and the density of oxygen at the exhaust temperature, resulting in the rate of oxygen consumption. This capability allowed the heat release rate of the fire to be recorded at regular intervals during the experiments independently of fuel consumption rate.

An elevated platform was constructed adjacent to the calorimeter to physically support smoke sampling equipment. Sampling probes were inserted into the duct, their 
lengths kept short to avoid heat losses and smoke aerosol agglomeration. Flow rates were selected to provide for isokinetic sampling within the exhaust duct in order to prevent a bias toward small or large smoke particle sizes. Instrumentation was provided to measure smoke particle size distribution and smoke particle mass. Grab samples were collected for gas chromatographic analysis of $\mathrm{CO}$ and $\mathrm{CO}_{2}$ levels in the exhaust for smoke yield calculations.

\subsection{Crude Oil Analysis}

Samples of each of the crude oils supplied by the Alaskan Department of Environmental Conservation (ADEC) were sent to a commercial laboratory for elemental analysis. The laboratory provided the mass fractions of carbon, hydrogen, nitrogen, and sulfur in the oils. The results are in Table 1.

Table 1. Elemental analysis of crude oils.

\begin{tabular}{|c|c|c|c|}
\hline Element & $\begin{array}{c}\text { Cook Inlet } \\
\text { (mass fraction) }\end{array}$ & $\begin{array}{c}\text { North Slope } \\
\text { (mass fraction) }\end{array}$ & $\begin{array}{c}\text { Louisiana [1] } \\
\text { (mass fraction) }\end{array}$ \\
\hline \hline Carbon & $0.8432 \pm 0.0058$ & $0.8511 \pm 0.0058$ & $0.862 \pm 0.002$ \\
\hline Hydrogen & $0.1247 \pm 0.0045$ & $0.1210 \pm 0.0045$ & $0.134 \pm 0.016$ \\
\hline Nitrogen & $<0.0050$ & $<0.0050$ & - \\
\hline Sulfur & $0.0019 \pm 0.0034$ & $0.0127 \pm 0.0034$ & $0.000 \pm 0.040$ \\
\hline
\end{tabular}

The density of each of the oils was determined at NIST by the mechanical oscillator method. This technique derives the density of a constant volume sample by measuring the period of electromagnetically induced vibrations. [7] Densities and API gravities of the oils, along with viscosities, and pour points where available [8] are listed in Table 2.

\subsection{Qualitative Burning Characteristics}

As illustrated in previous studies with other oils [9], the crude oils exhibited various burning stages when burned in the 1.2 meter pan. These stages include: ignition, growth, steady burning, boiling, and extinction. Cook Inlet and North Slope crude oils also followed this sequence, and all of the experiments were similar during the steady burning phase, in which measurements of burning rate and smoke yield were recorded.

Differences in ignition behavior, however, were noted between the two different oils. Cook Inlet crude, for example, was ignited in 1 to 2 seconds with a propane torch, resulting in rapid flame spread over the surface of the oil. The North Slope oil, in contrast, was more difficult to ignite, requiring the torch to be held on the surface of the oil for 20 seconds in some burns. The flame spread rate was also slower for North Slope 
Table 2. Crude oil properties.

\begin{tabular}{|c|c|c|c|}
\hline & Cook Inlet & North Slope & Louisiana \\
\hline \hline $\begin{array}{c}\text { Density }\left(\mathrm{kg} / \mathrm{m}^{3}\right) \\
\text { at } 26^{\circ} \mathrm{C}\end{array}$ & $841 \pm 1$ & $876 \pm 1$ & $842 \pm 1$ [2] \\
\hline $\begin{array}{c}\text { API Gravity } \\
\left(15 / 15^{\circ} \mathrm{C}\right)\end{array}$ & 35.0 & 28.5 & 36.0 \\
\hline $\begin{array}{c}\text { Kinematic Viscosity } \\
\left(\mathrm{mm}^{2} / \mathrm{s}\right) \text { at } 38^{\circ} \mathrm{C}\end{array}$ & - & 16.0 & 4.3 \\
\hline Pour Point $\left({ }^{\circ} \mathrm{C}\right)$ & - & -8 & -9 \\
\hline
\end{tabular}

crude, with some portions of the surface "flashing" repeatedly before sustaining flame. The ignition behavior of North Slope crude oil appeared to be a strong function of temperature in the ambient temperature range of the burn series which varied from 20 to 25 degrees celsius.

\subsection{Heat Release Rates and Burning Rates}

The heat release rates of the experiments are plotted as a function of time in Figures 1 and 2. These two graphs illustrate the progression of the fires from ignition to extinction. Ignition takes place at time zero, at which time the fire enters the growing phase indicated by an increasing heat release rate over time. The plateau on the graphs is indicative of the steady burning phase of the fire, during which all of the sampling takes place. Immediately following the steady phase is the boiling phase of the fire, the start of which is represented by the sudden increase and peaking of the heat release rate. The process of extinction begins when the heat release rate decreases from the peak heat release rate.

Using the pressure transducer at the base of the pan, the weight of crude oil and water may be derived at any time during the experiment. Converted to layer thicknesses via initial oil density, the change in the oil layer thickness may also be found as a function of time. Oil surface regression rates and mass loss rates during the steady burning regime may be found in Table 3 , along with heat release rates from oxygen consumption calorimetry.

As was the case with previous research, the mass loss rates were found to be relatively constant over the entire burn, although a measurable increase does take place during the boiling phase. [2] 


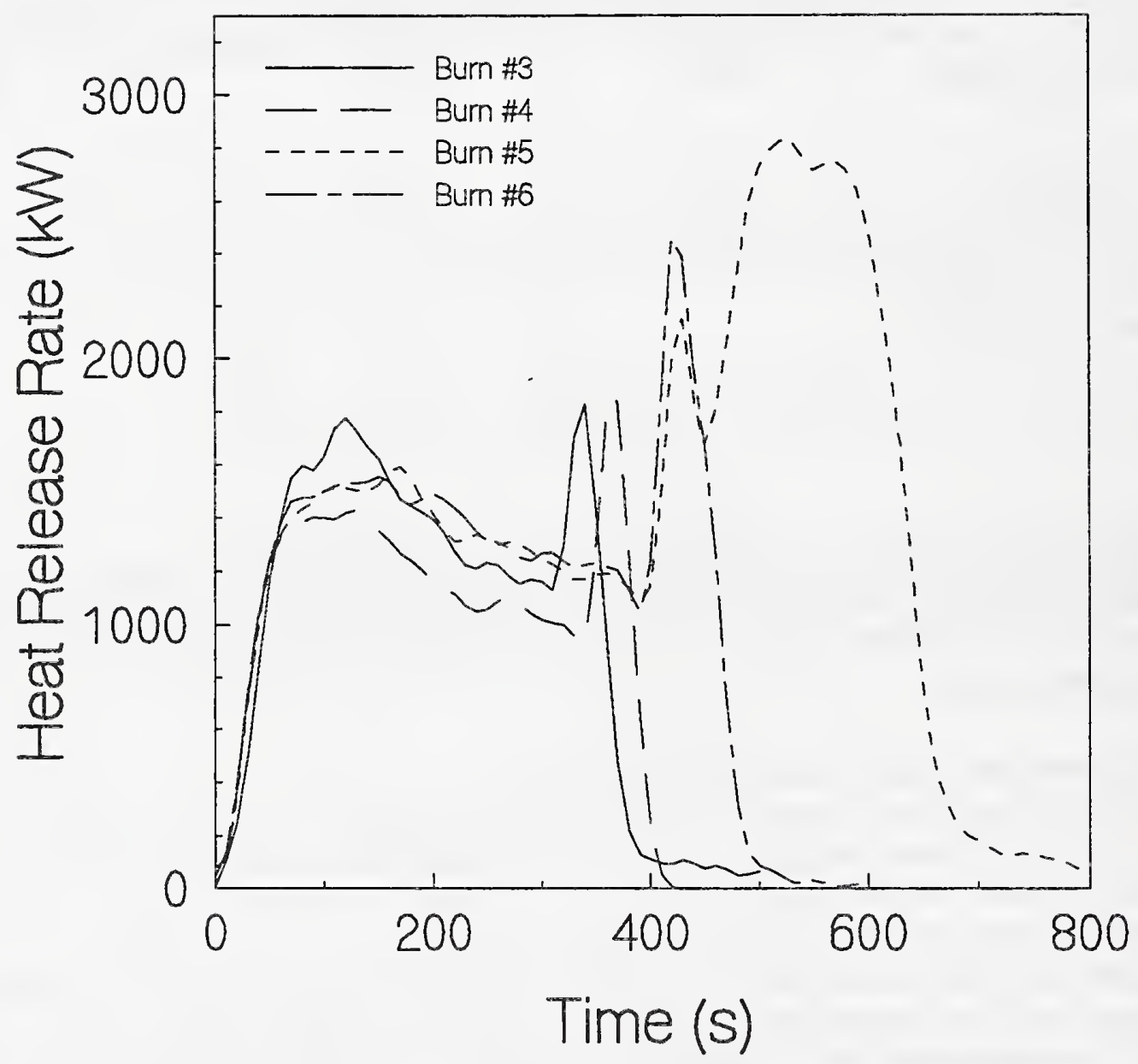

Figure 1. Heat release rate for North Slope crude oil burns. 


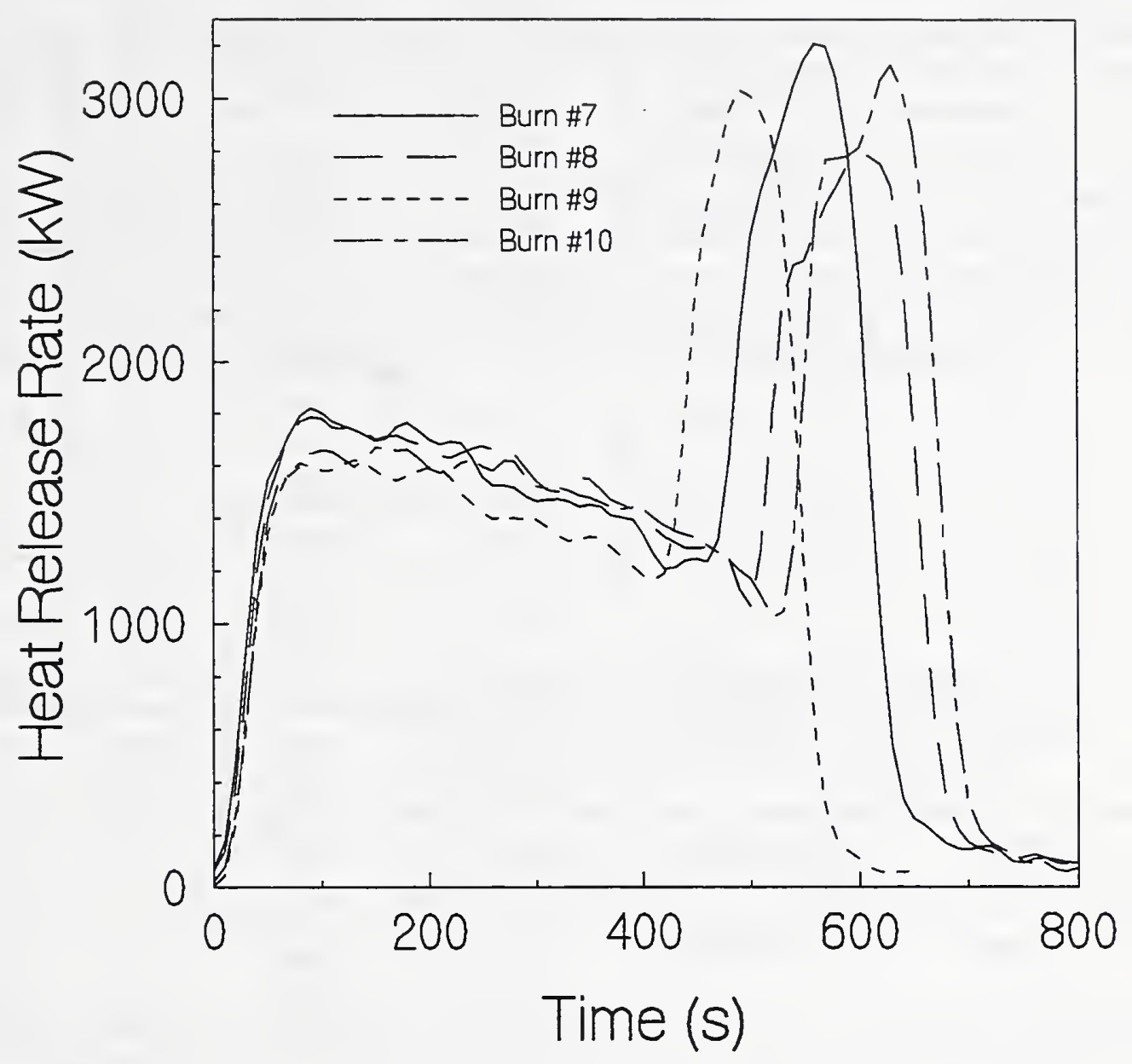

Figure 2. Heat release rate for Cook Inlet crude oil burns. 
Table 3. Average burning rate and heat release rate, steady burning phase.

\begin{tabular}{|c|c|c|c|c|c|}
\hline Burn no. & Oil & $\mathrm{kg} /\left(\mathrm{s} \cdot \mathrm{m}^{2}\right)$ & $\mathrm{kW} / \mathrm{m}^{2}$ & kW & $\mathrm{mm} / \mathrm{s}$ \\
\hline 1 & Louisiana & 0.027 & 1100 & 1300 & 0.032 \\
\hline 2 & North Slope & 0.032 & - & - & 0.036 \\
\hline 3 & North Slope & 0.032 & 1240 & 1400 & 0.036 \\
\hline 4 & North Slope & 0.029 & 1060 & 1200 & 0.033 \\
\hline 5 & North Slope & 0.032 & 1150 & 1300 & 0.036 \\
\hline 6 & North Slope & 0.026 & 1150 & 1300 & 0.030 \\
\hline 7 & Cook Inlet & 0.031 & 1330 & 1500 & 0.037 \\
\hline 8 & Cook Inlet & 0.037 & 1330 & 1500 & 0.044 \\
\hline 9 & Cook Inlet & 0.031 & 1240 & 1400 & 0.037 \\
\hline 10 & Cook Inlet & 0.032 & 1240 & 1400 & 0.038 \\
\hline average & Louisiana & $\begin{array}{c}0.033 \\
\pm 0.006\end{array}$ & $\begin{array}{r}1400 \\
\pm 200\end{array}$ & $\begin{array}{l}1600 \\
\pm 400\end{array}$ & $\begin{array}{r}0.039 \\
\pm 0.009\end{array}$ \\
\hline average & North Slope & $\begin{array}{r}0.030 \\
\pm 0.005 \\
\end{array}$ & $\begin{array}{l}1150 \\
\pm 70 \\
\end{array}$ & $\begin{array}{c}1300 \\
\pm 80 \\
\end{array}$ & $\begin{array}{r}0.034 \\
\pm 0.006 \\
\end{array}$ \\
\hline average & Cook Inlet & $\begin{array}{c}0.033 \\
\pm 0.005\end{array}$ & $\begin{array}{c}1280 \\
\pm 50\end{array}$ & $\begin{array}{c}1450 \\
\pm 60\end{array}$ & $\begin{array}{r}0.039 \\
\pm 0.006\end{array}$ \\
\hline
\end{tabular}

"Values are the average of burn 1 and a previous experiment [2] with values of $0.039 \mathrm{~kg} /\left(\mathrm{s} \cdot \mathrm{m}^{2}\right), 1630 \mathrm{~kW} / \mathrm{m}^{2}, 1800 \mathrm{~kW}, 0.046 \mathrm{~mm} / \mathrm{s}$.

\subsection{Smoke Yield}

The quantity of smoke emitted by the combustion process is an important parameter. Smoke emissions may be expressed as smoke yield, which is defined as the mass of smoke aerosol generated per mass of fuel consumed. Various methods may be used to measure smoke yield including the flux method, the carbon balance method, and the specific light extinction method. [10] In small scale experiments, the results of the three methods were within 6\%. [1] Since the carbon balance method is the only one of the three methods that can be used in both the laboratory and in the field, it is the method used in this study. 
The carbon balance method is based on the assumption that the mass of carbon in the fuel consumed is equal to the mass of carbon in the airborne combustion products. Given that the smoke aerosols are predominately carbon, it may be assumed that the carbon consumed by the fire is converted to particulate, $\mathrm{CO}$, and $\mathrm{CO}_{2}$ present in the smoke plume. [2] Isokinetic probes in the exhaust hood stack are used to sample a quantity of smoke, which is passed through a filter which removes the smoke aerosols. In order to average out small transients in burning behavior, the sample is taken over a period of 4 minutes during the steady phase of the fire. Due to the experimental procedure of sampling combustion products from the exhaust stack, it is necessary that the smoke aerosols and combustion gases be well mixed within the exhaust stack, and the smoke be sampled over a time great enough to average out fire fluctuations. These additional assumptions are valid for the experimental conditions, and the smoke yield is found from the following expression, as derived from previous work [2]:

$$
\text { smoke yield }=\frac{m_{s} Y_{C}}{m_{s}+12 n\left(\Delta \chi_{\mathrm{CO}_{2}}+\Delta \chi_{\mathrm{CO}}\right)}
$$

$\begin{array}{ll}\text { where: } & \begin{array}{l}m_{\mathrm{s}}= \\ \mathrm{Y}_{\mathrm{C}}=\end{array}\end{array} \quad \begin{aligned} & \text { mass of smoke collected on the filter } \\ & \mathrm{n}=\end{aligned} \quad \begin{aligned} & \text { mass fraction of carbon in the fuel } \\ & \text { moles of gas flowing through the filter } \\ & \text { difference in volume fraction of } \mathrm{CO}_{2} \text { between the } \\ & \text { sample and the background } \\ & \text { difference in volume fraction of } \mathrm{CO} \text { between the } \\ & \text { sample and the background }\end{aligned}$

Smoke yields for Louisiana, Cook Inlet, and North Slope crude oils have been calculated for each experiment and listed in Table 4.

\subsection{Particle Size Distribution}

The particle size distribution of smoke aerosols is important for the evaluation of smoke plume dispersion and health effects. Due to the irregular shape of smoke particles, which consist of chains of small spherules [9], the particles are typically classified by any one of a number of different equivalent diameters. In this study, the aerodynamic properties of the smoke aerosol are of primary concern, necessitating the use of equivalent aerodynamic diameter. The equivalent aerodynamic diameter of an irregularly shaped particle is the diameter of a smooth spherical particle, having a unit density of $1 \mathrm{~g} / \mathrm{cm}^{3}$, with the same terminal velocity as the smoke particle falling in air under the influence of gravity.

Particle size was measured during the steady portion of the fires using two particle impactors, each with 8 stages and a backup filter. The impactors are built in such a way that a number of overlapping perforated disks, or stages, force the particles to change 
Table 4. Average smoke yield, steady burning phase.

\begin{tabular}{|c|c|c|}
\hline Burn No. & Oil & Smoke Yield \\
\hline \hline 1 & Louisiana & 0.101 \\
\hline 2 & North Slope & 0.102 \\
\hline 4 & North Slope & 0.119 \\
\hline 5 & North Slope & 0.114 \\
\hline 6 & North Slope & 0.115 \\
\hline 7 & Cook Inlet & 0.088 \\
\hline 8 & Cook Inlet & 0.093 \\
\hline 9 & Cook Inlet & 0.093 \\
\hline 10 & Cook Inlet & 0.095 \\
\hline \hline average & Louisiana & $0.105 \pm 0.010$ \\
\hline average $^{*}$ & North Slope & $0.116 \pm 0.010$ \\
\hline average & Cook Inlet & $0.092 \pm 0.006$ \\
\hline
\end{tabular}

${ }^{*}$ Average of burn 1 and a previous experiment [2] with a value of 0.109 .

direction and follow the bulk flow of air through the holes in the stage. Some of the particles, however, are unable to navigate this path due to their momentum and are deposited on the stage. Each stage is designed to collect particles of a certain size range, specified by the manufacturer as the cutpoint diameter of the stage, which is the aerodynamic diameter that is collected at $50 \%$ efficiency. The cutpoint diameter decreases with each successive stage of the impactor. The cutpoint sizes for the impactors are listed in Table 5.

Two different types of impactor were used in this experimental series. The first was a full size unit, operating at a flow rate of 28.4 liters per minute. Due to the large size of this impactor, the mass of each stage is greater, as is the quantity of particulate collected. This combination of features helps decrease the uncertainty in the particle size measurements.

The second impactor used in this study was primarily designed to be worn by workers to monitor particulate exposure levels in the workplace. Due to the small size of this impactor, it has also been used as part of an airborne smoke plume sampling package for large scale fires. As a consequence of the size and weight advantages, 
Table 5. Impactor stage cutpoint sizes.

\begin{tabular}{|c|c|c|}
\hline & $\begin{array}{c}\text { Large Impactor } \\
(28.4 \text { liters/minute) }\end{array}$ & $\begin{array}{c}\text { Small Impactor } \\
(2.0 \text { liters/minute })\end{array}$ \\
\hline \hline Stage 1 $(\mu \mathrm{m})$ & 9.0 & 21.3 \\
\hline Stage 2 $(\mu \mathrm{m})$ & 5.8 & 14.8 \\
\hline Stage 3 $(\mu \mathrm{m})$ & 4.7 & 9.8 \\
\hline Stage 4 $(\mu \mathrm{m})$ & 3.3 & 6.0 \\
\hline Stage 5 $(\mu \mathrm{m})$ & 2.1 & 3.5 \\
\hline Stage 6 $(\mu \mathrm{m})$ & 1.1 & 1.55 \\
\hline Stage 7 $(\mu \mathrm{m})$ & 0.65 & 0.93 \\
\hline Stage 8 $(\mu \mathrm{m})$ & 0.43 & 0.52 \\
\hline Back-up Filter $(\mu \mathrm{m})$ & 0 & 0 \\
\hline
\end{tabular}

however, the flow rate of air sampled by the impactor is only 2.0 liters per minute. The capacities of the stages are also small, limiting the quantities of particulate that may be collected.

The smoke particle sizes for the oils have been plotted as cumulative distributions in Figures 3 through 6 . The distributions are very repeatable, especially with the high flow rate impactor. Notice that both the North Slope and the Cook Inlet oils yield almost identical results as the Louisiana burn. In reference to health concerns, the plots indicate that approximately $80 \%$ to $99 \%$ of the smoke aerosols collected have aerodynamic diameters of $10 \mu \mathrm{m}$ (microns) or less. This is significant since the quantity of particulate matter below $10 \mu \mathrm{m}$ cut size is a parameter used by the United States Environmental Protection Agency to gauge particulate pollution in ambient air. [11] 


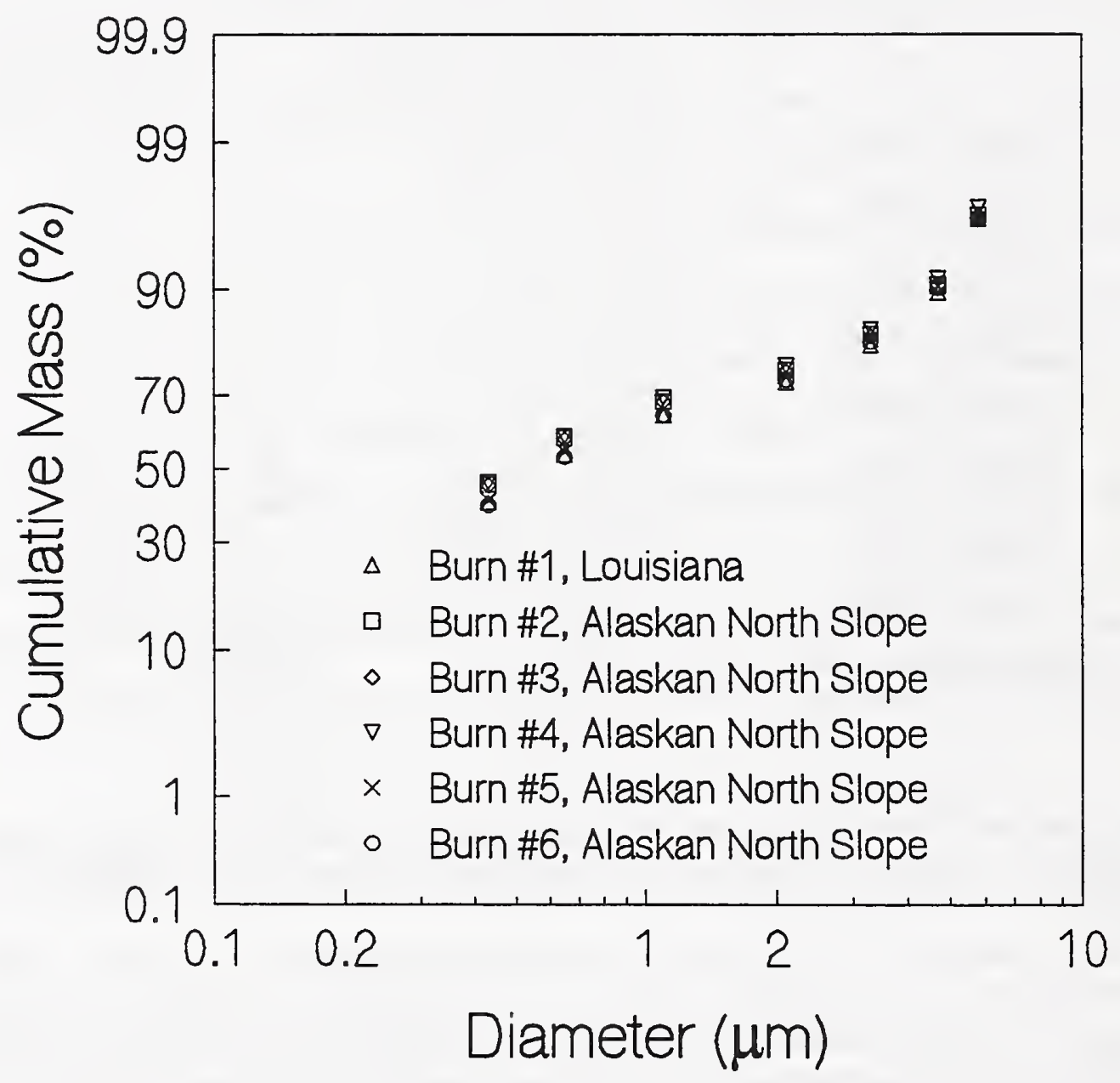

Figure 3. Smoke aerosol size distribution for North Slope crude oil burns using the high flow rate impactor. 


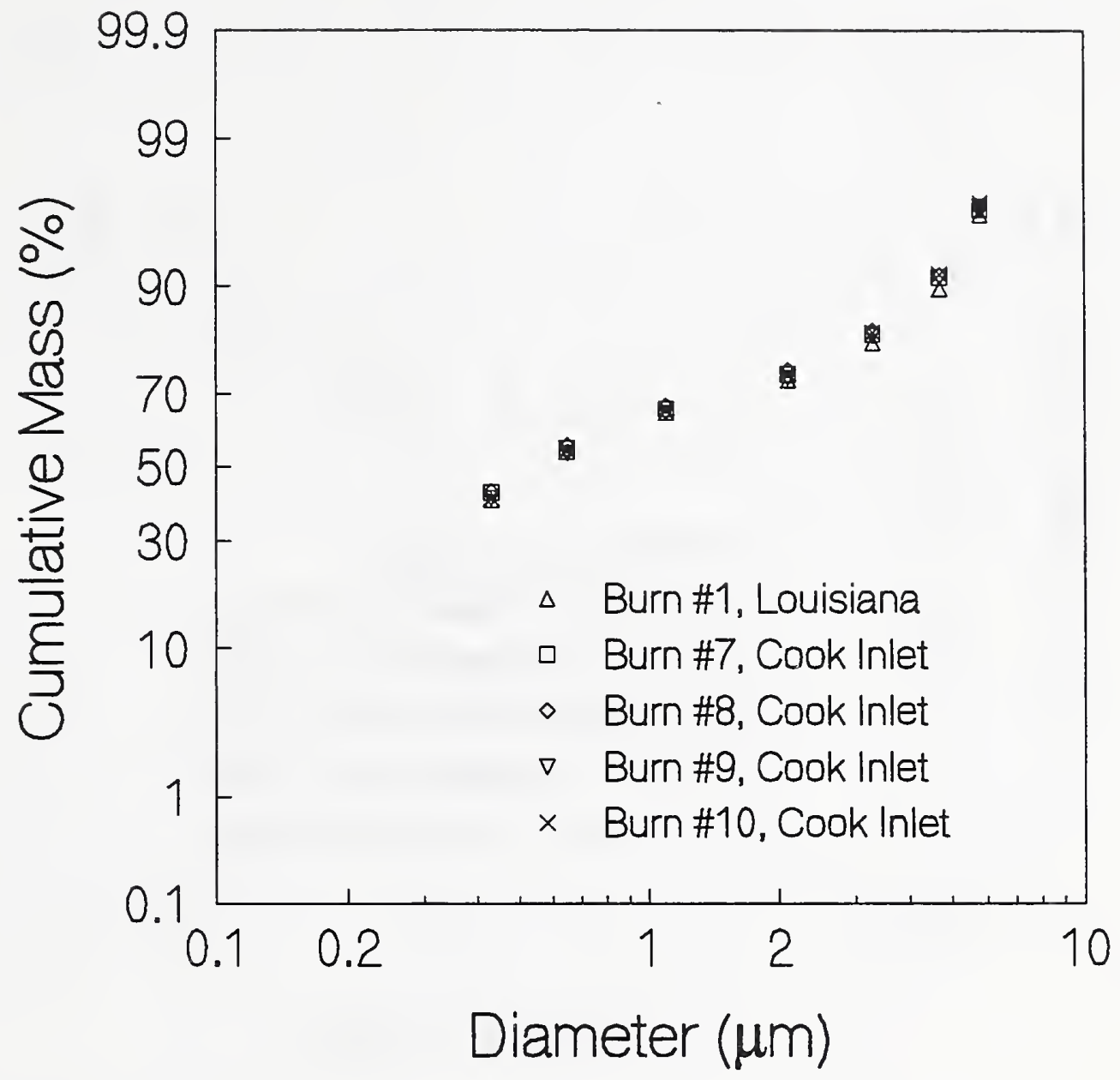

Figure 4. Smoke aerosol size distribution for Cook Inlet crude oil burns using the high flow rate impactor. 


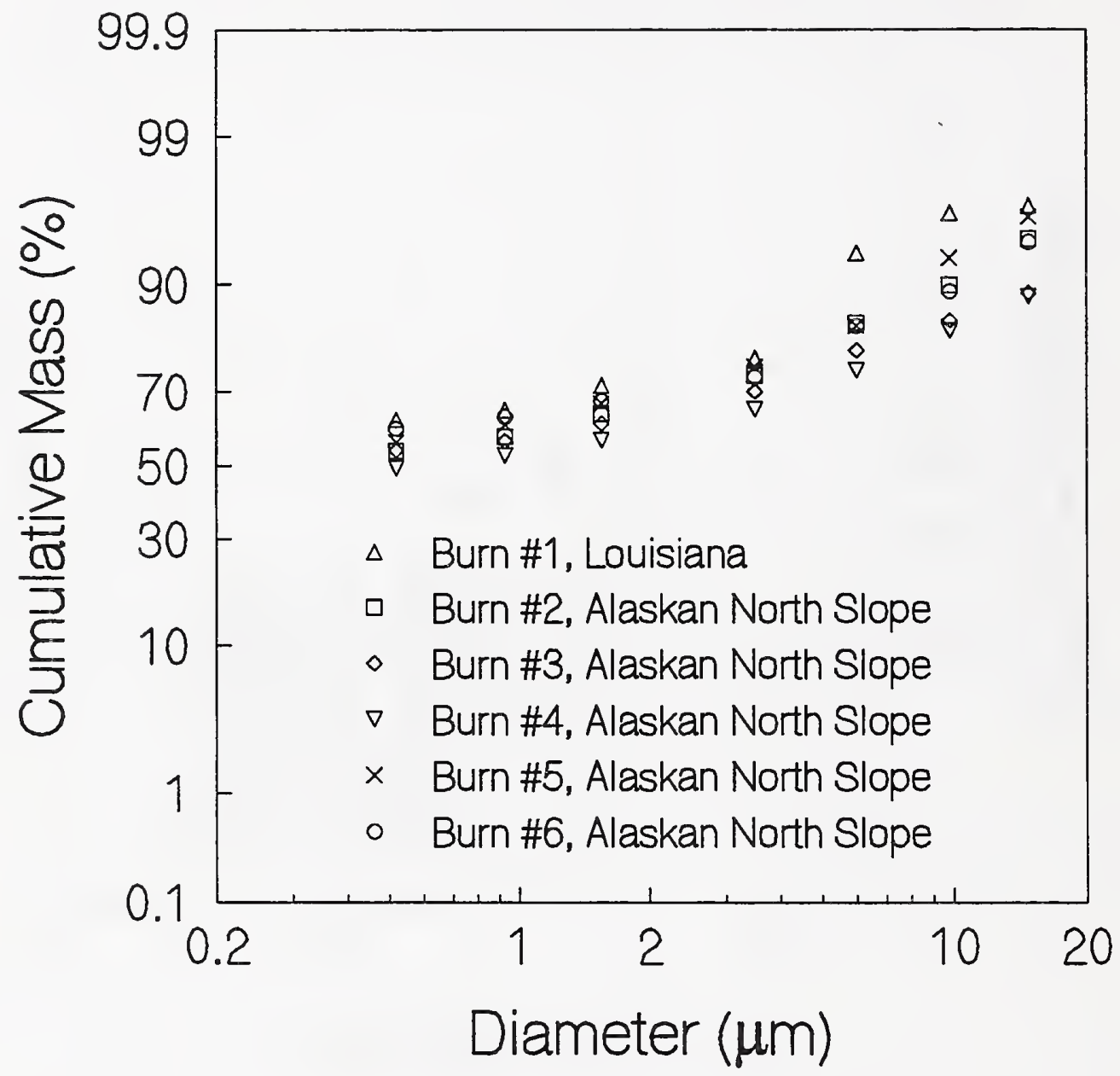

Figure 5. Smoke aerosol size distribution for North Slope crude oil burns using the personal impactor. 


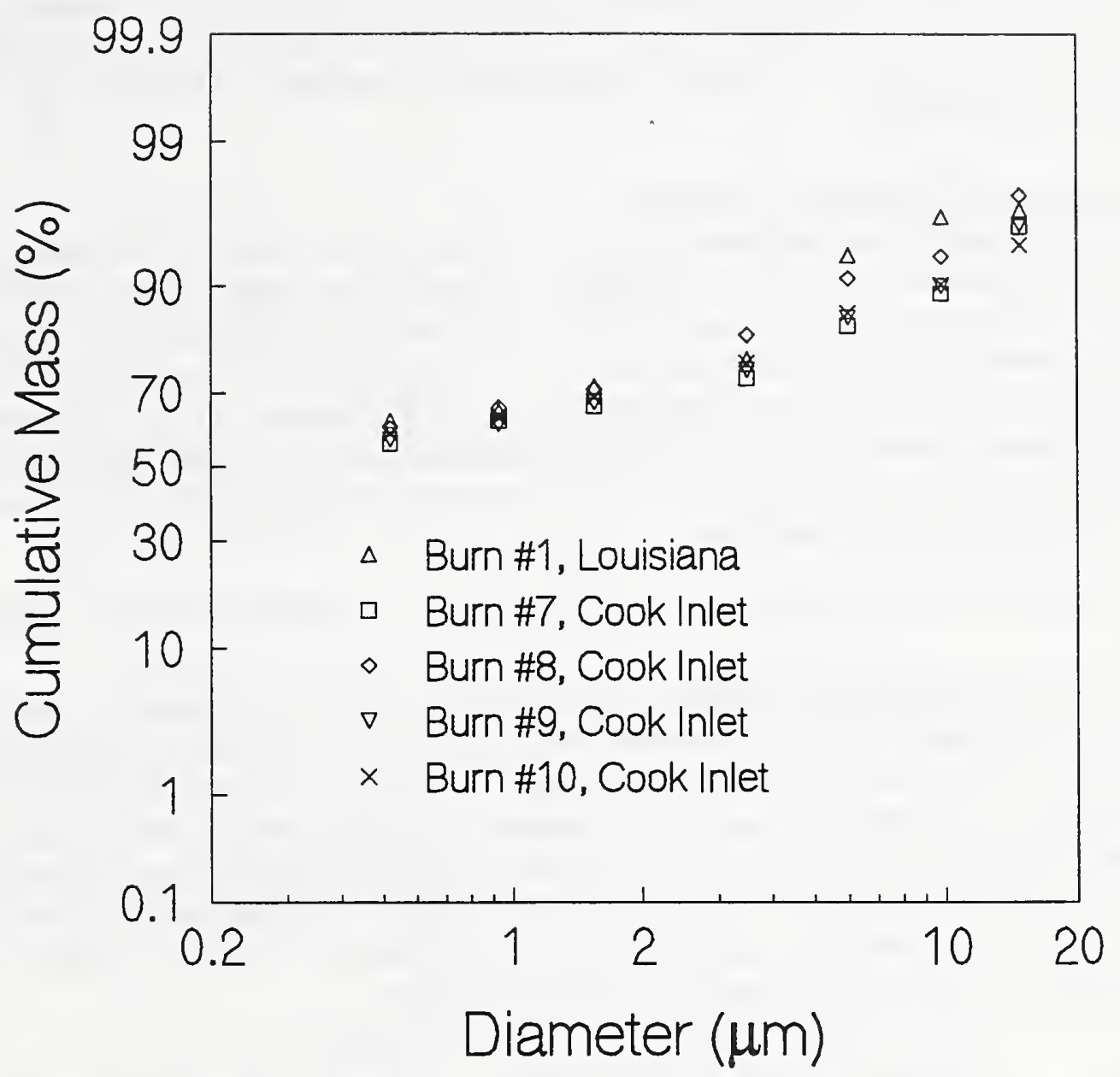

Figure 6. Smoke aerosol size distribution for Cook Inlet crude oil burns using the personal impactor. 


\section{PART 2: DETERMINATION OF SMOKE PLUME CALCULATION INPUTS}

\subsection{Fire Scenario}

We must now formulate scenarios of interest to which the smoke dispersion model will be applied. It is assumed that crude oil from a spill is being burned within the roughly semi-circular apex area of a boom. We will consider two burn areas, $232 \mathrm{~m}^{2}\left(2500 \mathrm{ft}^{2}\right)$ and $465 \mathrm{~m}^{2}\left(5000 \mathrm{ft}^{2}\right)$.

\subsection{Derivation of Scaling Factors}

Comparing the burning rates of Cook Inlet and North Slope crude oils to previous work with Louisiana crude oil is necessary to predict the large scale behavior of the former oils. Analyses of the Louisiana burn conducted in this study, and of experiments conducted previously have been graphed in Figure 7 . This plot clearly demonstrates an increase in burning rate as the diameter of the fire increases. At fire diameters larger than 6.88 meters, however, the burning rate plateaus, and becomes independent of fire size. From this graph, a scaling factor may be defined relating the laboratory burning rate to the large scale burning rate, ie.

$$
\text { large scale burning rate }=\text { scaling factor } \times \text { laboratory burning rate }
$$

Due to the similarities of the three crude oils at burns of 1.2 meters in diameter, the scaling factor is assumed to be the same for all of the oils. The burning rate of the three crude oils is thereby expected to increase by a factor of 1.7 when the fire diameter is increased from 1.2 meters to diameters greater than 6.88 meters, which would include both fires stated in the fire scenario. Since heat release rates from field experiments are derived from the burning rate, the heat release rate will have the same scaling factor as burning rate. The results of applying the scaling factor of 1.7 to burning rate, and consequently to heat release rate, are listed in Table 6.

Table 6. Estimated large scale burning rate, heat release rate, and smoke yield.

\begin{tabular}{|c|c|c|c|}
\hline Oil & Burning rate & Heat release rate & Smoke yield \\
\hline \hline Cook Inlet & $\begin{array}{c}0.056 \mathrm{~kg} /\left(\mathrm{s} \bullet \mathrm{m}^{2}\right) \\
5.9 \mathrm{gal} /\left(\mathrm{hr} \bullet \mathrm{ft}^{2}\right)\end{array}$ & $\begin{array}{c}2180 \mathrm{~kW} / \mathrm{m}^{2} \\
6.90 \times 10^{5} \mathrm{Btu} /\left(\mathrm{hr} \bullet \mathrm{ft}^{2}\right)\end{array}$ & 0.092 \\
\hline North Slope & $\begin{array}{c}0.051 \mathrm{~kg} /\left(\mathrm{s} \cdot \mathrm{m}^{2}\right) \\
5.1 \mathrm{gal} /\left(\mathrm{hr} \bullet \mathrm{ft}^{2}\right)\end{array}$ & $\begin{array}{c}1960 \mathrm{~kW} / \mathrm{m}^{2} \\
6.20 \times 10^{5} \mathrm{Btu} /\left(\mathrm{hr} \bullet \mathrm{ft}^{2}\right)\end{array}$ & 0.116 \\
\hline
\end{tabular}




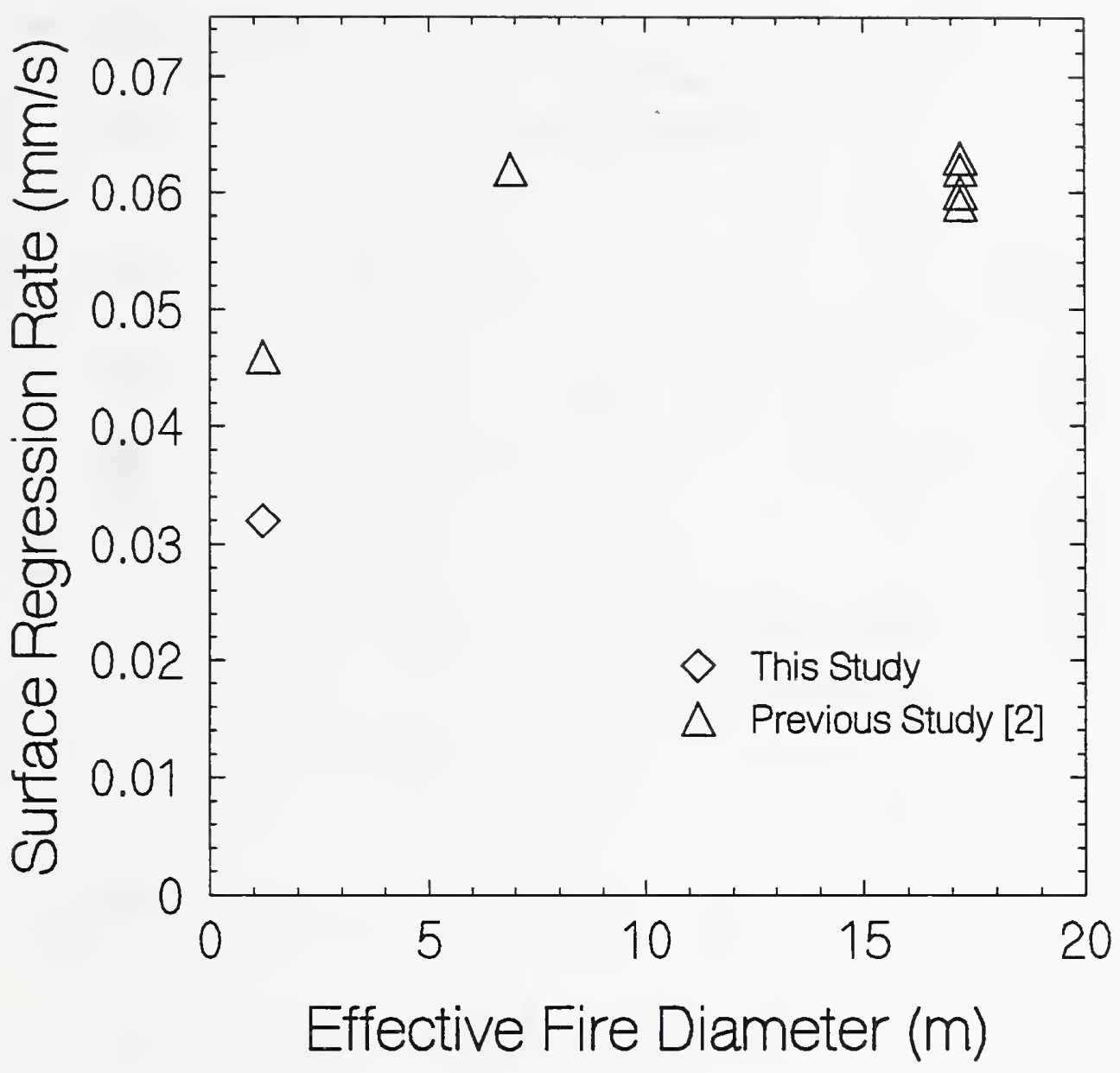

Figure 7. Louisiana crude oil surface regression rate. Previous [2] and new data.

A scaling factor may also be derived for smoke yield. Smoke yield has been plotted as a function of fire diameter in Figure 8. From this graph, it can be seen that the smoke yield is relatively constant for fire diameters greater than 1.2 meters. Therefore, the scaling factor would be 1.0, and the smoke yields for the large scale fire scenarios would be expected to be the same as the smoke yields from the laboratory burns. The scaling factor for smoke yield has been applied to the laboratory data, and the results listed in Table 6. 


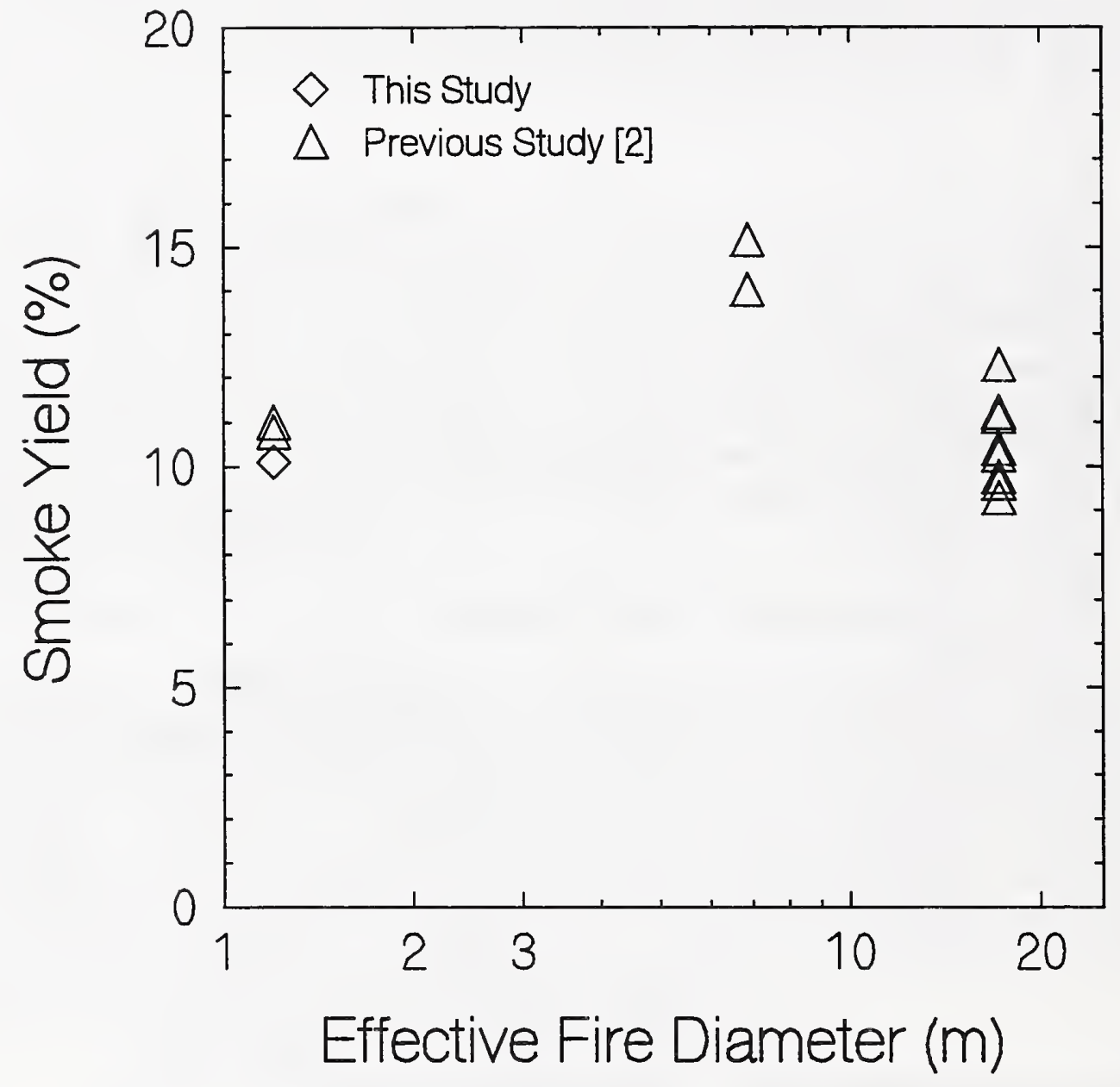

Figure 8. Louisiana crude oil smoke yield. Previous [2] and new data.

Smoke particle size measurements from all three of the oils showed nearly identical results, indicating that the trends observed for the Louisiana burns may be extrapolated to both Cook Inlet and North Slope oils. The particle distributions from the 1.2 meter burns are also comparable to previous results for 17.2 meter burns, illustrated by Figure 9 , indicating a scaling factor of 1.0 . Therefore, a similar distribution would be expected for a full scale burn of North Slope or Cook Inlet crude oils, resulting in $80 \%$ to $99 \%$ of the smoke aerosols meeting the under $10 \mu \mathrm{m}$ criterion. This distribution represents the smoke aerosol in the portion of the plume close to the fire, however, and 


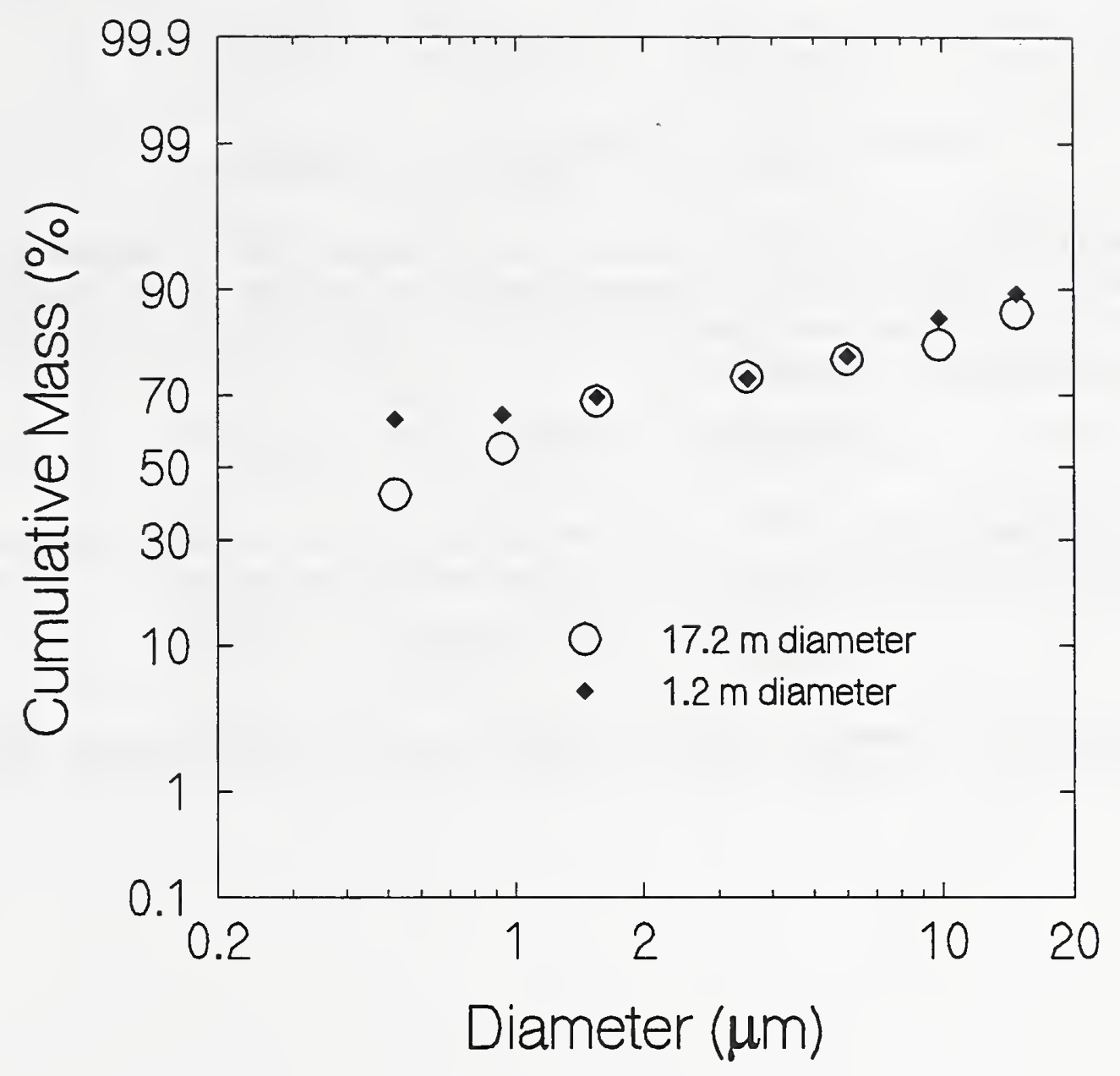

Figure 9. Smoke aerosol size distribution for Louisiana crude oil using the personal impactor. [2]

would be expected to change as the plume progressed and the mechanisms of agglomeration and settling became significant.

\subsection{Plume Model Inputs}

The general scaled results from the previous section are now used to derive the specifics of the fire scenarios. As an example, the first case would involve a Cook Inlet crude oil burn of $465 \mathrm{~m}^{2}$. Based on experimental data we assume that the heat and 
mass release from the fire is more or less steady. Given the heat release and burning rate values from Table 6 , and the burning area of the fire, the total heat release rate and burning rate for the fire are calculated in Equations 3 and 4 respectively.

$$
\begin{gathered}
\dot{Q}=465 \mathrm{~m}^{2} \times 2180 \mathrm{~kW} / \mathrm{m}^{2}=1000 \mathrm{MW} \\
\dot{M}=465 \mathrm{~m}^{2} \times 0.056 \mathrm{~kg} /\left(\mathrm{s} \cdot \mathrm{m}^{2}\right)=26.0 \mathrm{~kg} / \mathrm{s}
\end{gathered}
$$

The "heat loading" of the fire, or the convective heat release rate, is defined as the total heat release of the fire minus the fraction released as radiation. Limited radiation data from large fires [12] suggest a radiative fraction of approximately $10 \%$, resulting in the following calculation of heat loading:

$$
\text { heat loading }=1000 \mathrm{MW} \times 0.90=900 \mathrm{MW}
$$

The smoke yield of the burn is expected to be $9.2 \%$ from Table 6 , so the smoke particulate mass flux rate, referred to as "mass loading", is given by:

$$
\text { mass loading }=0.092 \times 26.0 \mathrm{~kg} / \mathrm{s}=2.39 \mathrm{~kg} / \mathrm{s}
$$

This procedure is repeated for the other three scenarios, with the results recorded in Table 7. 
Table 7. Fire Scenario Summary

\begin{tabular}{|c|c|c|c|c|}
\hline & $\begin{array}{c}\text { Scenario } 1 \\
\text { Cook Inlet } \\
\text { Crude }\end{array}$ & $\begin{array}{c}\text { Scenario } 2 \\
\text { Cook Inlet } \\
\text { Crude }\end{array}$ & $\begin{array}{c}\text { Scenario } 3 \\
\text { North Slope } \\
\text { Crude }\end{array}$ & $\begin{array}{c}\text { Scenario } 4 \\
\text { North Slope } \\
\text { Crude }\end{array}$ \\
\hline $\begin{array}{l}\text { Fire } \\
\text { Area }\end{array}$ & $\begin{array}{c}465 \mathrm{~m}^{2} \\
\left(5000 \mathrm{ft}^{2}\right)\end{array}$ & $\begin{array}{c}232 \mathrm{~m}^{2} \\
\left(2500 \mathrm{tt}^{2}\right)\end{array}$ & $\begin{array}{c}465 \mathrm{~m}^{2} \\
\left(5000 \mathrm{tt}^{2}\right)\end{array}$ & $\begin{array}{c}232 \mathrm{~m}^{2} \\
\left(2500 \mathrm{ft}^{2}\right)\end{array}$ \\
\hline $\begin{array}{l}\text { Fire } \\
\text { Output } \\
\text { Power }\end{array}$ & $\begin{array}{c}1000 \mathrm{MW} \\
\left(3.45 \times 10^{9}\right. \\
\text { Btu/hr) }\end{array}$ & $\begin{array}{c}500 \mathrm{MW} \\
\left(1.73 \times 10^{9}\right. \\
\text { Btu/hr) }\end{array}$ & $\begin{array}{c}910 \mathrm{MW} \\
\left(3.10 \times 10^{9}\right. \\
\text { Btu/hr) }\end{array}$ & $\begin{array}{c}450 \mathrm{MW} \\
\left(1.55 \times 10^{9}\right. \\
\text { Btu/hr) }\end{array}$ \\
\hline $\begin{array}{l}\text { Heat } \\
\text { Loading }\end{array}$ & $\begin{array}{c}900 \mathrm{MW} \\
\left(3.11 \times 10^{9}\right. \\
\text { Btu/hr) }\end{array}$ & $\begin{array}{c}450 \mathrm{MW} \\
\left(1.56 \times 10^{9}\right. \\
\text { Btu/hr) }\end{array}$ & $\begin{array}{c}820 \mathrm{MW} \\
\left(2.79 \times 10^{9}\right. \\
\text { Btu/hr) }\end{array}$ & $\begin{array}{c}405 \mathrm{MW} \\
\left(1.40 \times 10^{9}\right. \\
\text { Btu/hr) }\end{array}$ \\
\hline $\begin{array}{l}\text { Burning } \\
\text { Rate }\end{array}$ & $\begin{array}{c}26.0 \mathrm{~kg} / \mathrm{s} \\
\left(2.94 \times 10^{4}\right. \\
\mathrm{gal} / \mathrm{hr})\end{array}$ & $\begin{array}{c}13.0 \mathrm{~kg} / \mathrm{s} \\
\left(1.47 \times 10^{4}\right. \\
\mathrm{gal} / \mathrm{hr})\end{array}$ & $\begin{array}{c}23.7 \mathrm{~kg} / \mathrm{s} \\
\left(2.57 \times 10^{4}\right. \\
\mathrm{gal} / \mathrm{hr})\end{array}$ & $\begin{array}{c}11.8 \mathrm{~kg} / \mathrm{s} \\
\left(1.29 \times 10^{4}\right. \\
\mathrm{gal} / \mathrm{hr})\end{array}$ \\
\hline $\begin{array}{l}\text { Mass } \\
\text { Loading }\end{array}$ & $\begin{array}{c}2.39 \mathrm{~kg} / \mathrm{s} \\
(5.28 \mathrm{lbm} / \mathrm{s})\end{array}$ & $\begin{array}{c}1.20 \mathrm{~kg} / \mathrm{s} \\
(2.63 \mathrm{lbm} / \mathrm{s})\end{array}$ & $\begin{array}{c}2.75 \mathrm{~kg} / \mathrm{s} \\
(6.07 \mathrm{lbm} / \mathrm{s})\end{array}$ & $\begin{array}{c}1.37 \mathrm{~kg} / \mathrm{s} \\
(3.03 \mathrm{lbm} / \mathrm{s})\end{array}$ \\
\hline
\end{tabular}




\section{PART 3: SMOKE PLUME TRAJECTORY MODELING}

The LES (Large Eddy Simulation) smoke plume trajectory model is being developed to address the need for accurate predictions of downwind smoke dispersion from large buoyant sources such as oil spill fires to support the decision process about the application of in situ burning in response to oil spills. This model differs from most of the atmospheric dispersion models in use today because it is a deterministic rather than an empiricalmodel; that is, the approach taken is to solve the governing equations of motion directly rather than relying on empirical formulae which approximate the extent of the dispersion. These empirical models typically assume the pollutant of interest to be Gaussian distributed in the plane perpendicular to the direction of the prevailing wind. The parameters defining the distribution are estimated from experiments. Unfortunately, the problem of in situ burning of crude oil is inappropriate for these types of models for two reasons: (1) The nature of the "source" is different than what is normally assumed, a smokestack, and (2) the size of the source is well beyond those considered in industrial applications and thus outside of the experimental parameter range.

Because the LES model approaches the dispersion problem from first principles, it is more flexible, and ultimately easier to apply because it reduces the number of empirical parameters demanded of the user. The long range goal of the LES modeling study is to provide high resolution predictions that can account for the actual terrain and atmospheric conditions in the vicinity of the spill. LES version 2.0 used in this study is limited to predictions of downwind smoke concentration for uniform winds and flat terrain. This version represents an improvement over the previous version [1] with the inclusion of atmospheric dispersion, more efficient computation, and clearer presentation of results.

\subsection{Mathematical Model}

We assume that the plume may be described in terms of the steady-state convective transport by a uniform ambient wind of heated gases and particulate matter introduced into the atmosphere by a continuously burning fire. We do not intend to model the fire itself, but rather the plume of smoke which emanates from it. Only the convective heat release rate and the fraction of the fuel converted to particulate matter need be specified from experiments. The simulation begins several fire diameters downwind of the fire, where the flow field is characterized by relatively small temperature perturbations, minimal radiation effects, and a velocity field dominated by the prevailing wind. In this region the plume gases ascend to a point in the atmosphere of neutral buoyancy, and then gradually disperse. The trajectory of the plume is governed by the ambient wind, the atmospheric stratification and the level of turbulent motion. Since it is not our objective to calculate the local meteorology, it is assumed that this information is available. The wind is taken as uniform, but the temperature may vary with height according to a prescribed profile.

Given these assumptions, the mathematical model of a smoke plume consists of the conservation equations of mass, momentum and energy which govern the absolute

temperature $T$, pressure $p$, density $\rho$, and crosswind velocity components $(v, w)$ in a 
plane $(y, z)$ normal to the direction $(x)$ of the uniform ambient wind (See Figure 10). It is



Figure 10: Three dimensional view of a computed smoke plume in the first few kilometers of its development. The height of the viewbox is 1 kilometer, the length 8 kilometers, and the crosswind length $4 \mathrm{~km}$. The wind speed is $6 \mathrm{~m} / \mathrm{s}$. The computation is initialized by prescribing the temperature and particulate distribution in the plane spanned by the $y$ and $z$ coordinates. Then the plume is constructed as the initial plane is swept downwind.

convenient to divide the temperature and pressure fields into mean background values $T_{0}(z)$ and $p_{0}(z)$ plus perturbations induced by the fire, $\tilde{T}$ and $\tilde{p}$, respectively. Similarly, the density $\rho$ is decomposed into an ambient density $\rho_{0}$ and a small thermally induced perturbation $\tilde{\rho}$. which is related to the temperature perturbation through the equation of state taken in the small disturbance, low Mach number form appropriate to this problem

$$
\frac{\rho-\rho_{0}}{\rho_{0}}=-\frac{T-T_{0}}{T_{0}}
$$

The ambient density is related to the background pressure through the hydrostatic balance

$$
\frac{d p_{0}}{d z}=-\rho_{0} g
$$

where $g$ represents the acceleration of gravity. Assuming that the perturbations to the background temperature and density are small beyond a few diameters of the fire downwind of the firebed, we can write the conservation equations describing the steady-state plume in the Boussinesq approximation as follows

Conservation of mass

$$
\frac{\partial v}{\partial y}+\frac{\partial w}{\partial z}=0
$$


Conservation of lateral and vertical momentum

$$
\begin{aligned}
& \rho_{0}\left(U \frac{\partial v}{\partial x}+v \frac{\partial v}{\partial y}+w \frac{\partial v}{\partial z}\right)+\frac{\partial \tilde{p}}{\partial y}=\mu\left(\frac{\partial^{2} v}{\partial y^{2}}+\frac{\partial^{2} v}{\partial z^{2}}\right) \\
& \rho_{0}\left(U \frac{\partial w}{\partial x}+v \frac{\partial w}{\partial y}+w \frac{\partial w}{\partial z}\right)+\frac{\partial \tilde{p}}{\partial z}+\tilde{\rho} g=\mu\left(\frac{\partial^{2} w}{\partial y^{2}}+\frac{\partial^{2} w}{\partial z^{2}}\right)
\end{aligned}
$$

Conservation of energy

$$
\rho_{0} c_{p}\left(U \frac{\partial \tilde{T}}{\partial x}+v \frac{\partial \tilde{T}}{\partial y}+w \frac{\partial \tilde{T}}{\partial z}\right)-\left(\frac{d p_{0}}{d z}-\rho_{0} c_{p} \frac{d T_{0}}{d z}\right) w=k\left(\frac{\partial^{2} \tilde{T}}{\partial y^{2}}+\frac{\partial^{2} \tilde{T}}{\partial z^{2}}\right)
$$

In these equations, $c_{p}$ is the specific heat of air, $k$ the thermal conductivity, and $\mu$ the dynamic viscosity. The uniform ambient wind speed $U$ is taken to be constant and larger than the crosswind velocity components. This assumption is quite realistic several flame lengths downwind of the firebed. Since $U$ does not change, there is no need for a windward component of the momentum equations.

The three-dimensional, steady state system of equations above can be considered as a two-dimensional, time-dependent system by replacing the downwind spatial coordinate $x$ with a temporal coordinate $t=x / U$. We then have an initial value problem in which the solution is initially prescribed in a plane perpendicular to the direction of the prevailing wind. This initial plane is taken to be a few fire diameters downwind of the fire. Since the details of the firebed are not being simulated, the only information about the fire required is the overall convective heat release rate $\dot{Q}$ and the particulate mass flux $\dot{M}$. The initial temperature and particulate distributions in the plume cross section are assumed to be Guassian and satisfy the following integrals

$$
\begin{aligned}
\int_{-\infty}^{\infty} \int_{0}^{\infty} \rho_{0} c_{p} U \tilde{T} d z d y & =\dot{Q} \\
\int_{-\infty}^{\infty} \int_{0}^{\infty} \rho_{p} U d z d y & =\dot{M}
\end{aligned}
$$

where $\rho_{p}$ is the concentration of particulate matter, defined in units of mass per unit volume. In the simulations, the particulate matter is represented by Lagrangian particles which are advected with the flow. Initially, the crosswind velocity components $v$ and $w$ are assumed to be zero. No-flux, free-slip boundary conditions are prescribed at the ground, consistent with the assumed uniformity of the prevailing wind and the resolution limits of the calculation. At the outer and upper edges of the computational domain, the perturbation temperature, perturbation pressure, and windward component of vorticity are set to zero. Figure 10 shows the results of a sample computation, illustrating the position of the initial slice and the extent of the computational domain.

Atmospheric turbulence effects mixing on a wide range of scales, extending to scales which are smaller than the resolution of the calculations performed here. There are two mechanisms by which we introduce turbulent atmospheric motions into the simulation. 


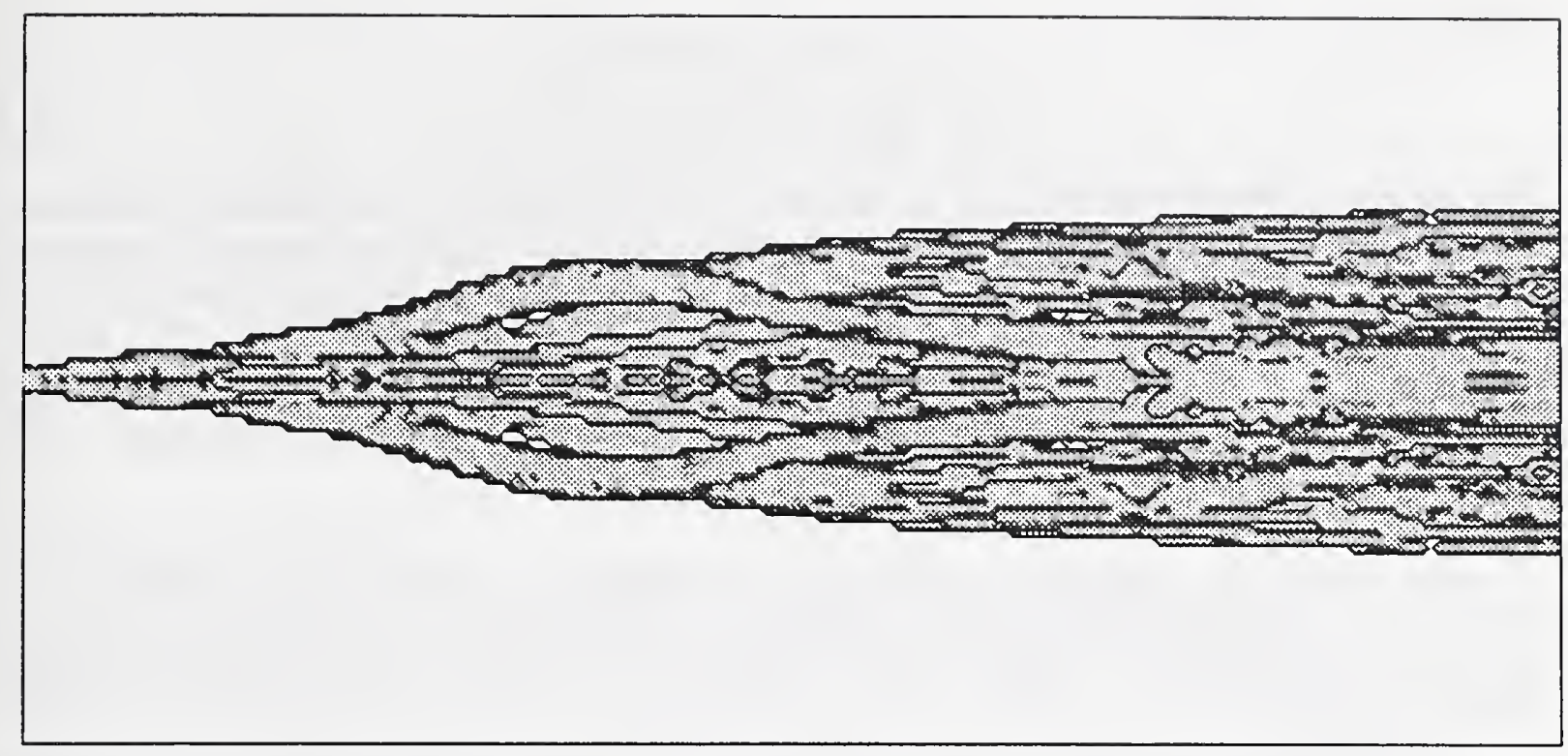

Figure 11: View of the smoke plume from underneath. Notice that in the absence of any background atmospheric motion, the plume is characterized by two large vortices which entrain much of the particulate matter. This figure shows only the fire-induced flow field.

First, the small scale mixing is represented by a constant eddy viscosity $\mu$, which is taken to be three orders of magnitude greater than the viscosity of air. The choice is governed by the desire for resolution limits in the five to fifteen meter range which are needed to capture the large scale fire induced eddy motions. This requirement, together with the knowledge that the dissipative effects operate at a scale $R e^{-\frac{1}{2}}$ times smaller than the overall geometric scale (the stabilization height of the plume for this problem), translates into Reynolds numbers of the order $10^{4}$. Thermal conductivity is treated in a similar manner to viscosity, thus the Prandtl number $\operatorname{Pr}=c_{p} \mu / k$ remains of order unity. The plume depicted in Figure 10 represents the solution of Equations (9)-(12) with these values of viscosity and thermal conductivity.

Unfortunately, the magnitude of the viscosity and thermal conductivity included in Equations (9)-(12) cannot account for larger scale atmospheric motions, which may be thought of as variations of the prevailing wind over a time scale of minutes to hours. These deviations can be measured with an anemometer, and are introduced into the model through random perturbations to the trajectories of the Lagrangian particles which represent the particulate matter. Thus, the motion of each particle is governed by the fireinduced velocity field $(U, v, w)$, found by solving the conservation equations above, plus a perturbation velocity field $\left(0, v^{\prime}, w^{\prime}\right)$ which represents the random temporal and spatial variations of the ambient wind. The perturbation velocity components are derived from 
the recursive relations

$$
\begin{gathered}
v^{\prime}(t+\delta t)=R_{v}(\delta t) v^{\prime}(t)+v^{\prime \prime} \\
w^{\prime}(t+\delta t)=R_{w}(\delta t) w^{\prime}(t)+w^{\prime \prime}
\end{gathered}
$$

The term $v^{\prime \prime}$ is a random variable with Gaussian distribution whose variance is that of $v^{\prime}$ multiplied by $\left(1-R_{v}^{2}\right)$, ensuring that the variance of the velocity does not change from one time step to another. The term $w^{\prime \prime}$ is handled the same way. The functions $R_{v}(\delta t)$ and $R_{w}(\delta t)$ are Lagrangian correlation coefficients, taken as exponentials

$$
\begin{aligned}
& R_{v}(\delta t)=e^{-\delta t / \tau_{v}} \\
& R_{w}(\delta t)=e^{-\delta t / \tau_{w}}
\end{aligned}
$$

The parameter $\tau$ is indicative of the period of atmospheric fluctuations. Appropriate values for various meteorological conditions are given by Draxler [14]. Generally speaking, $\tau$ is on the order of several minutes, and it does not have much of an effect the outcome of the simulations.

The initialization of the recursive relations (15) and (16) determines the overall level of turbulence in the atmosphere. The initial velocity perturbations $v^{\prime}(0)$ and $w^{\prime}(0)$ are randomly assigned from a Gaussian distribution of mean zero and variance $\sigma_{v}^{2}$ and $\sigma_{w}^{2}$, respectively. In order to prescribe these initial variations, we have adopted the classification scheme of Pasquill and Gifford [15] to categorize local meteorological conditions and the level of atmospheric motion. These classes are defined in Table 8 . Corresponding to each

Table 8: Key to Pasquill stability categories

\begin{tabular}{|c||c|c|c|c|c|}
\hline \multicolumn{1}{|c||}{$\begin{array}{c}\text { Surface } \\
\text { Wind } \\
\mathrm{m} / \mathrm{s}\end{array}$} & \multicolumn{3}{c|}{ Day } & \multicolumn{2}{c|}{ Night } \\
\cline { 2 - 6 } & Incoming Solar Radiation & \multicolumn{2}{c|}{ Cloud Cover } \\
\hline \hline$<2$ & Strong & Moderate & Slight & Low & High \\
\hline $2-3$ & A & A-B & B & & \\
\hline $3-5$ & B & B & C & E & F \\
\hline $5-6$ & C & C-D & C & D & E \\
\hline$>6$ & C & D & D & D & D \\
\hline
\end{tabular}

Stability Category are values for the angular variance of the prevailing wind direction in the lateral and vertical directions, denoted by $\sigma_{\theta}^{2}$ and $\sigma_{\phi}^{2}$, respectively. The initial variance of the lateral perturbation velocity $v^{\prime}(0)$ in Equation (15) is found from the relation

$$
\sigma_{v}=U \sin \sigma_{\theta}
$$

The vertical perturbation velocity $w^{\prime}$ is determined in a similar way. Reference [16] contains a discussion of these parameters and methods of evaluating them. For this report, we 
have adopted the following values of $\sigma_{\theta}$ corresponding to the Pasquill Stability Categories A-F: $25^{\circ}, 20^{\circ}, 15^{\circ}, 10^{\circ}, 5^{\circ}$, and $2.5^{\circ}$, respectively. The values of $\sigma_{\phi}$ are taken to be $16^{\circ}$, $12^{\circ}, 10^{\circ}, 6^{\circ}, 3^{\circ}$, and $2^{\circ}$, respectively. These values of wind variation vary from one type of terrain to another. In application, best results can be expected if local measurements of average wind speed and variance are used in the calculations. These values generally vary with height. Since version 2.0 of the model assumes a constant vertical wind profile, it is best to choose the values which correspond to the expected stabilization height of the plume. Also, the averaging should be done over a time period which roughly corresponds to the expected burning time. The suggested values above can be applied to burn times of ten minutes to an hour.

\subsection{Numerical Method}

If the prevailing wind speed is greater than the velocities induced in the crosswind direction by the fire, then the downwind spatial component $x$ may be considered a temporal variable, and Equations (9)-(12) may be solved with a time marching procedure which tracks a planar slice of particulate matter through the steady-state plume. The initial temperature distribution of the plume cross section is assumed to be Guassian; its center and standard deviation are estimated from observed mesoscale experiments [1]. The equations are solved in nondimensional form using a relatively simple finite difference technique. All spatial derivatives are centrally differenced, and the solution is advanced in time (i.e. the initial distributions of temperature and particulate matter are tracked downwind) with a second order Runge-Kutta scheme. The computational domain spanning the crosswind plane is a rectangle whose ratio of vertical to lateral lengths is usually 1 to 4 . This area is divided into rectangular cells (preferably square) with a uniform spacing in each direction. For the calculations reported here, a grid with 64 cells in the vertical direction and 256 cells in the lateral direction was used. This grid resolves the crosswind plane into cells from 5 to 20 meters on a side, depending on the scalings applied. On current generation work stations, this is a modest calculation, requiring about 10 megabytes of system memory and 10 to 20 minutes of CPU time, depending on the specific processor used. 


\section{PART 4: RESULTS}

Part 2 of this report contains a discussion of the derivation of input parameters for the Large Eddy Simulation model. Briefly, it is assumed that spilled crude oil is being burned in the confines of a boom. We mainly consider two fire sizes, one corresponding to a burning area of $465 \mathrm{~m}^{2}\left(5000 \mathrm{ft}^{2}\right)$ and the other $232 \mathrm{~m}^{2}\left(2500 \mathrm{ft}^{2}\right)$. (There are also a few runs with a $10000 \mathrm{ft}^{2}$ fire for comparison purposes.) We assume that the heat and mass release rates presented in Table 7 are more or less steady for burn times on the order of one hour.

Figure 12 presents the results from a sample run. First, Figure $12(\mathrm{~A})$ is a typical temperature profile for the Cook Inlet region in the winter. The effect of the temperature inversion on the plume rise is evident in Figure 12(B) which shows the crosswind extent of hour-averaged plume particulate concentrations of 150 and $300 \mu \mathrm{g} / \mathrm{m}^{3} 5$ kilometers downwind of the burn site. Figure $12(\mathrm{C})$ is a similar plot showing the downwind extent of these concentration levels in the plume. Figure 12(D) displays the concentrations at the ground level, where the darker shaded areas indicate values higher than $150 \mu \mathrm{g} / \mathrm{m}^{3}$. The term "ground level" refers to the first 10 to 20 meters of the atmosphere, reflecting the resolution of the finite difference approximation of the conservation equations described above. Finally, Figure $12(E)$ is included to quantify the previous contour plot. It shows the decrease in the ground concentration along the plume centerline.

For each region, Cook Inlet or North Slope, we consider the burning of crude oil from that particular region, i.e. North Slope crude oil is burned on the North Slope. The heat release rates and the smoke yields for the two types of oil considered in this report are similar and do not dramatically change the results of the computations. For example, the case presented in Figure 13 is the same as that in Figure 12 except that we consider the burning of North Slope crude instead of Cook Inlet crude in the vicinity of Cook Inlet. There is very little change in the final result. The North Slope crude has a lower heat release rate and a higher particulate yield, thus its burning produces a slightly less elevated plume which has higher particulate concentrations than that produced from the burning of Cook Inlet crude. Given the assumptions and simplifications inherent in the model, this small difference in crude oil properties is of little consequence.

Table 9 summarizes the results of the simulations. We consider four different meteorological conditions, corresponding to the Cook Inlet and North Slope regions in the summer and winter. Since the ultimate objective of the modeling is to predict the downwind and lateral extent of harmful concentrations of particulate matter, there is a column entitled "Extent of $150 \mu \mathrm{g} / \mathrm{m}^{3}$ " which indicates the farthest downwind extent of

ground level concentrations in excess of $150 \mu \mathrm{g} / \mathrm{m}^{3}$ averaged over one hour. Ground level concentrations in excess of $300 \mu \mathrm{g} / \mathrm{m}^{3}$ did not extend beyond two kilometers for all cases shown; and most often not even beyond one kilometer. These concentrations represent averaged values over time periods on the order one hour. The Appendix includes a synopsis of all the runs listed in Table 9. 
Finally, note that Table 9 includes a few simulations of a larger fire, one which would cover an area of about $930 \mathrm{~m}^{2}\left(10,000 \mathrm{ft}^{2}\right)$. It is clear that even though the fire size is double the area of the $465 \mathrm{~m}^{2}$ case, and the heat and mass release rates are double, the particulate concentrations at the ground are not double. The reason for this is that the plume will rise higher when the fire is larger. The higher elevation of the plume causes greater dispersion, and thus the particulate matter is spread over a larger area. To consider fires even larger than the ones considered here, the model would have to be altered to account for the fact that multiple plumes might arise from a fire spread over a large area. 
(A) TEMPERATURE PROFILE

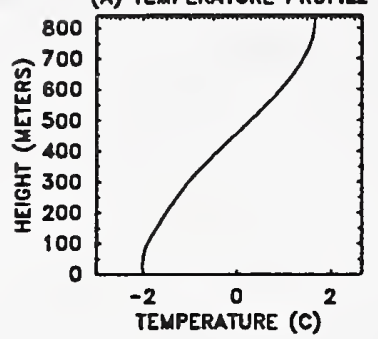

(B) CROSSWINO CONCENTRATION AT 5000. METERS

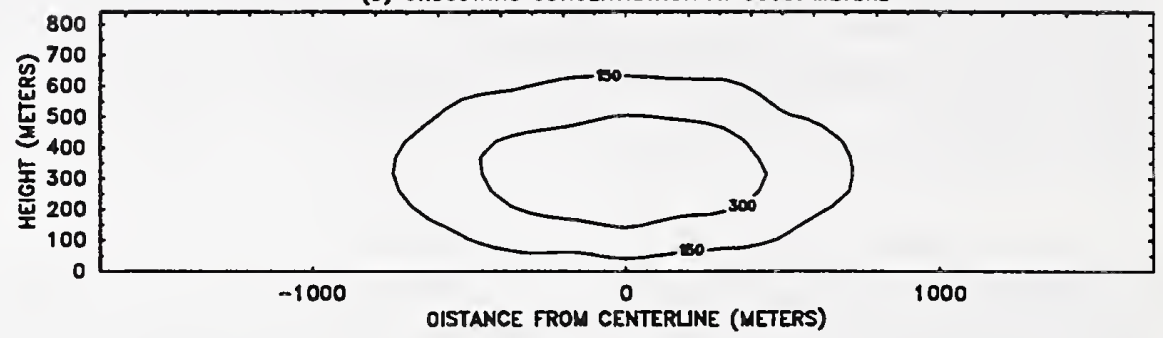

(c) VERTICAL CENTERLINE CONCENTRATION

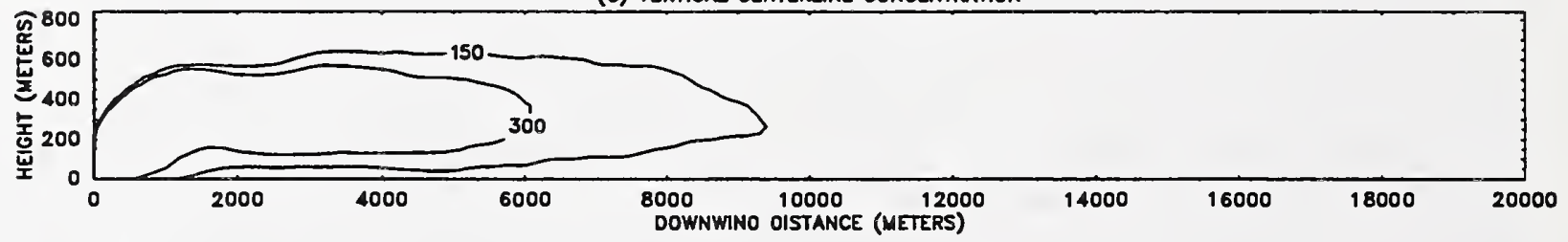

(0) GROUND LEVEL CONCENTRATION

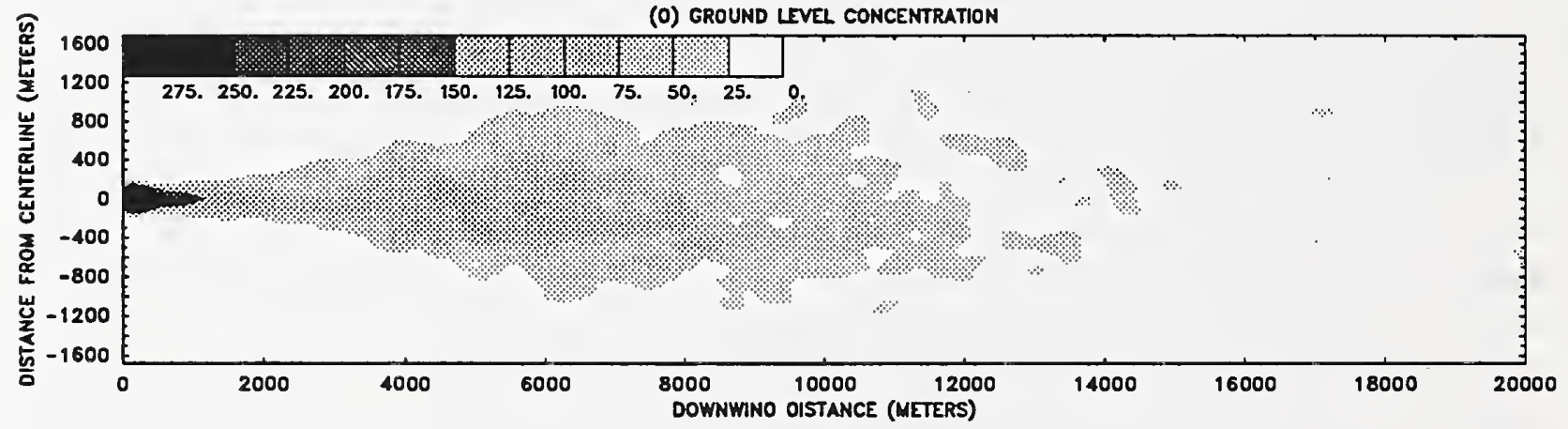

(E) GROUNO CENTERLINE CONCENTRATION

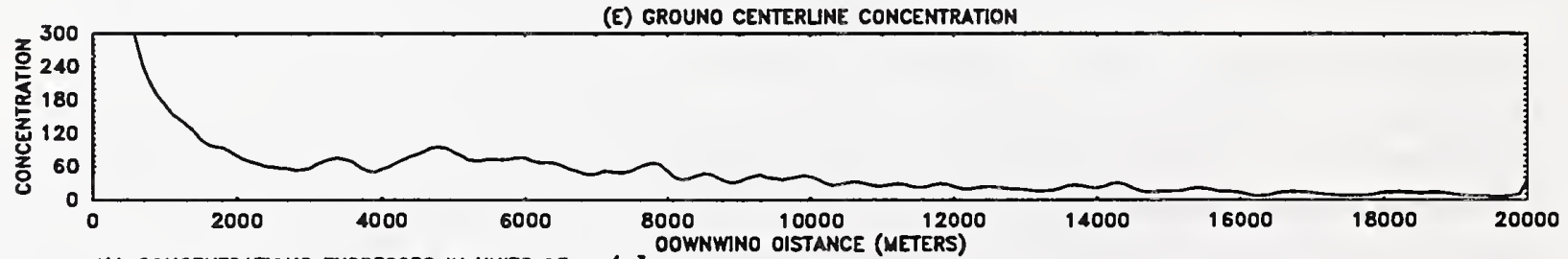
ALL CONCENTRATIONS EXPRESSEO IN UNITS OF $\mu \mathrm{g} / \mathrm{m}^{\mathrm{s}}$

Figure 12: Sample results for a typical LES plume model run. This case considers the burning of Cook Inlet crude oil in the vicinity of the Cook Inlet. 
(A) TEMPERATURE PROTLE

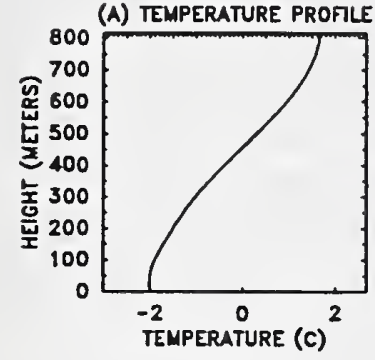

(8) CROSSWIND CONCENTRATION AT 5000. METERS



(c) VERTICAL CENTERUNE CONCENTRATION

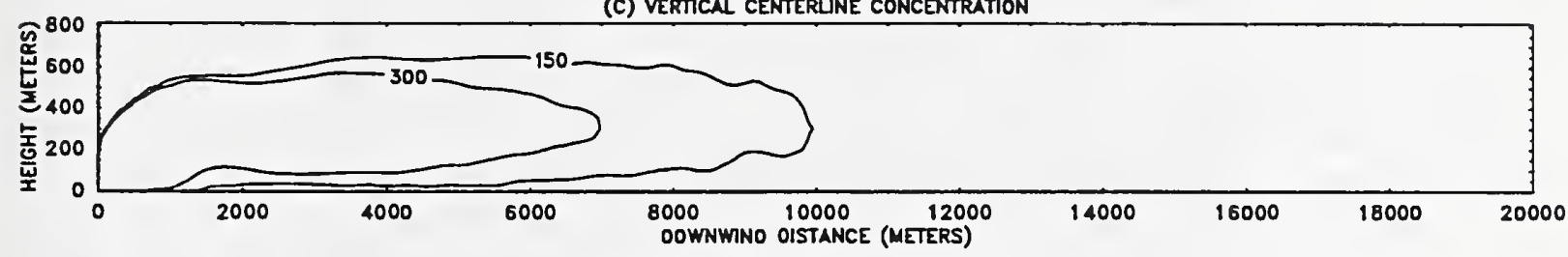

(0) GROUNO LEVEL CONCENTRATION

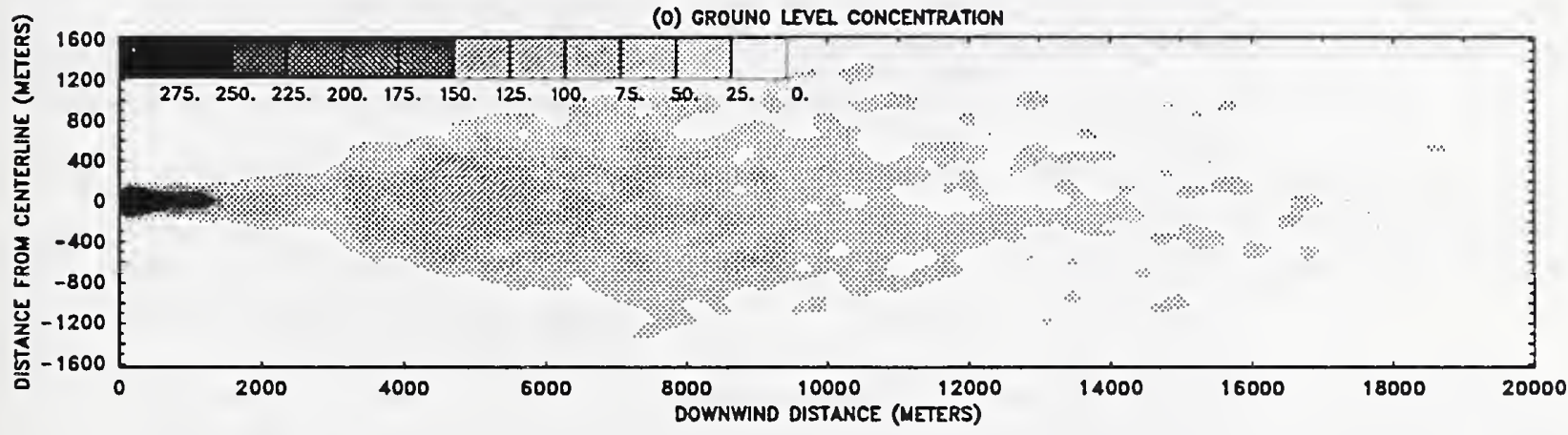

(E) GROUND CENTERLNE CONCENTRATION

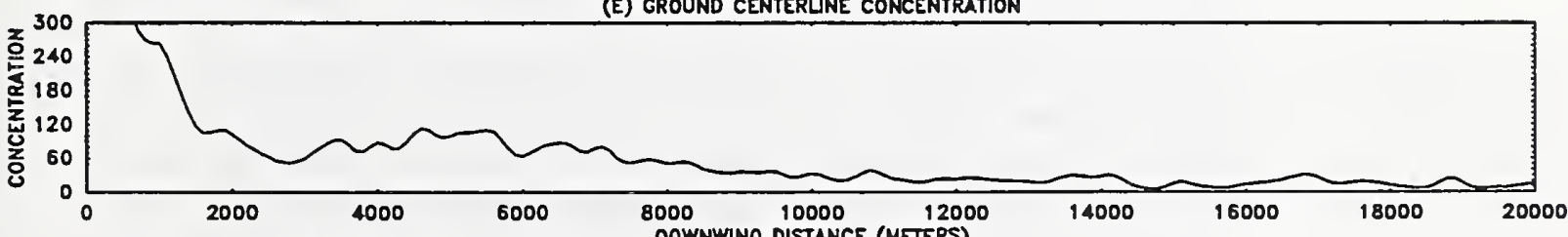
Al CONCENTRATIONS EXPRESSED IN UNTSS OF $\mu \mathrm{g} / \mathrm{m}^{\mathrm{a}}$

Figure 13: Sample results for a typical LES plume model run. This case considers the burning of North Slope crude oil in the vicinity of the Cook Inlet, and should be compared to the previous example in which Cook Inlet crude is burned under the same conditions. 
Table 9: Summary of LES smoke plume trajectory model runs

\begin{tabular}{|c|c|c|c|c|}
\hline Location & Season & $\begin{array}{c}\text { Stability } \\
\text { Class }\end{array}$ & $\begin{array}{l}\text { Wind } \\
\text { Speed } \\
(\mathrm{m} / \mathrm{s})\end{array}$ & $\begin{array}{c}\text { Extent of } \\
150 \mu \mathrm{g} / \mathrm{m}^{3} \\
(\mathrm{~km})\end{array}$ \\
\hline \multicolumn{5}{|c|}{ Burning Area of $232 \mathrm{~m}^{2}\left(2500 \mathrm{ft}^{2}\right)$} \\
\hline Cook Inlet & Summer & C & 4 & $<1$ \\
\hline Cook Inlet & Summer & D & 8 & $<1$ \\
\hline Cook Inlet & Summer & $\bar{D}$ & 12 & 1.5 \\
\hline Cook Inlet & Winter & $\mathrm{C}$ & 4 & $<1$ \\
\hline Cook Inlet & Winter & D & 8 & $<1$ \\
\hline Cook Inlet & Winter & $\bar{D}$ & 12 & 2 \\
\hline North Slope & Summer & C & 4 & 2.5 \\
\hline North Slope & Summer & D & 8 & 3 \\
\hline North Slope & Summer & $\bar{D}$ & 12 & 2.5 \\
\hline North Slope & Winter & $\mathrm{C}$ & 4 & 3 \\
\hline North Slope & Winter & $\bar{D}$ & 8 & 4 \\
\hline North Slope & Winter & $\bar{D}$ & 12 & 2.5 \\
\hline \multicolumn{5}{|c|}{ Burning Area of $465 \mathrm{~m}^{2}\left(5000 \mathrm{ft}^{2}\right)$} \\
\hline Cook Inlet & Summer & C & 4 & $<1$ \\
\hline Cook Inlet & Summer & D & 8 & $<1$ \\
\hline Cook Inlet & Summer & $\bar{D}$ & 12 & 1 \\
\hline Cook Inlet & Winter & $\mathrm{C}$ & 4 & $<1$ \\
\hline Cook Inlet & Winter & D & 8 & $<1$ \\
\hline Cook Inlet & Winter & $\bar{D}$ & 12 & 2 \\
\hline North Slope & Summer & $\mathrm{C}$ & 4 & 7 \\
\hline North Slope & Summer & D & 8 & 4 \\
\hline North Slope & Summer & $\bar{D}$ & 12 & 4 \\
\hline North Slope & Winter & C & 4 & 5 \\
\hline North Slope & Winter & D & 8 & 5 \\
\hline North Slope & Winter & $D$ & 12 & 4.5 \\
\hline \multicolumn{5}{|c|}{ Burning Area of $930 \mathrm{~m}^{2}\left(10000 \mathrm{ft}^{2}\right)$} \\
\hline Cook Inlet & Summer & D & 8 & $<1$ \\
\hline Cook Inlet & Winter & $\bar{D}$ & 8 & 2 \\
\hline North Slope & Summer & D & 8 & 2 \\
\hline North Slope & Winter & D & 8 & 7 \\
\hline
\end{tabular}




\section{PART 5: CONCLUSION}

North Slope and Cook Inlet crude oils have been burned on water in a 1.2 meter pan with an oil layer thickness of $25 \pm 4 \mathrm{~mm}$. The smoke yields of these fires were found to be $11.6 \% \pm 1.0$ and $9.2 \% \pm 0.6$ per mass of fuel consumed, respectively. The burning rate of North Slope crude was $0.030 \pm 0.005 \mathrm{~kg} / \mathrm{s} \cdot \mathrm{m}^{2}$, while the burning rate of Cook Inlet crude oil was $0.033 \pm 0.005 \mathrm{~kg} / \mathrm{s} \cdot \mathrm{m}^{2}$. Particles with equivalent aerodynamic diameters of 10 microns or less were found to represent 80 to $90 \%$ of the total mass of smoke aerosol sampled. It should be noted that all of these measurements are averages over the steady burning regime.

Due to similarities at laboratory scale, the scaling factors derived by comparing Louisiana crude oil burns of various sizes are applied to North Slope and Cook Inlet crude oil burns. The scaling factor is 1.7 for burning and heat release rates, and 1.0 for smoke yield and particle size distribution. Therefore, the burning rates of North Slope and Cook Inlet crude oil burns at equivalent diameters greater than 6.88 meters are assumed to be $0.051 \mathrm{~kg} /\left(\mathrm{s} \cdot \mathrm{m}^{2}\right)$ and $0.056 \mathrm{~kg} /\left(\mathrm{s} \cdot \mathrm{m}^{2}\right)$, respectively. The heat release rate is taken as $1960 \mathrm{~kW} / \mathrm{m}^{2}$ for North Slope and $2180 \mathrm{~kW} / \mathrm{m}^{2}$ for Cook Inlet crude oils. The large scale mass based smoke yield for North Slope and Cook Inlet crude oils are assumed to be $11.6 \%$ and $9.2 \%$, respectively.

We use these extrapolated values of heat release and mass flux to predict the downwind spread of combustion products. Despite the reasonably high resolution of the calculations, uncertainties need to be recognized.

- It is difficult to predict the convective heat release rate and the particulate mass flux from the fire itself. Even though we have confidence in the laboratory scale measurements, there is some uncertainty in extrapolating the results to the scales anticipated for in situ burning of oil.

- The height to which the plume rises is very sensitive to the background temperature stratification. The model results vary significantly in response to changes in the temperature lapse rate of a few degrees per kilometer.

- The dispersion parameters reflecting the magnitude of the wind fluctuations may vary depending on the terrain of the burn site. The values used for the simulations presented here are based on empirical estimates of plume dispersion. Better results will be obtained if the wind fluctuations are measured directly with the use of an anemometer.

- Finally, there is very little experimental data with which to verify the model.

Nevertheless, a study of a broad range of conditions has yielded useful results. After a number of simulations, certain patterns and trends develop which instill confidence in the overall methodology. For the conditions considered in the report and summarized in Table 9, we found that the LES plume trajectory model predicts that hour-averaged ground 
level particulate concentrations of $150 \mu \mathrm{g} / \mathrm{m}^{3}$ or higher do not extend beyond the first 5 kilometers downwind of the burn site, nor do these levels extend outside a path of about a kilometer in width. Given the uncertainties discussed above, these estimates can be extended by a factor of safety of two to account for uncertainties in the input parameters.

It should be recognized that the practical application of in situ burning of oil spills might involve more than one fire burning at a time, with varying burn times. For the moment, the LES model discussed in this report considers only the burning of one fire. To account for multiple burns which are far enough away from each other to be considered independent, it is reasonable to superimpose the results of several simulations to yield a total concentration at any location as the sum of the concentrations from the respective runs. If the fires are close together (in relation to the overall size of the plumes), then they may be considered as one burn.

Although not part of this study, another practical consideration of in situ burning is the time required to clear the air following the extinguishing of a burn. This question is difficult to answer because of terrain effects. It is reasonable to expect the air above 30 meters in altitude to clear relatively quickly, and the speed of the prevailing wind offers a rough guide as to how long the last of the particulates from the fire pass. However, at the surface, where knowledge of particulate concentration is most important, it is difficult to predict with the present version of the model how long it will take for the air to clear. The reason for the difficulty is the fact that if the terrain is rough, or if it is an urban setting, pockets of high concentration may get "trapped" between buildings or in a valley. Local meteorological and topographical conditions would thus play a crucial role in determining the time required for the air to clear.

\section{ACKNOWLEDGEMENTS}

This work was sponsored by the Alaska Department of Environmental Conservation (ADEC). The LES model and experimental techniques for smoke measurement used in this work were developed in part under funding provided by the Mineral Management Service, U.S. Department of the Interior.

The authors would like to thank the following people for their assistance: Essential support in conducting the burns, maintaining the test instrumentation and collecting the test data was provided by Richard Zile, Laurean DeLauter, and Gary Roadarmel. Assistance in reducing the data was provided by Emil Braun. Photographic and videotape footage of the tests was provided by Jay McElroy. Complete videotape of all the tests was provided by Richard Zile. Howard Baum and Ronald Rehm developed the LES model, and have provided a great amount of advice as to its application. Roland Draxler of the Air Resources Laboratory provided background and references pertaining to atmospheric dispersion. Gary Hufford and Joel Curtis of the National Weather Service, Alaska Region provided advice and data on the meteorological conditions of Cook Inlet and the North Slope regions. Finally, John Whitney of NOAA and Larry Dietrick of ADEC helped to define the problem and evaluate the results. 


\section{REFERENCES}

[1] Evans, D.D. et al., "In-Situ Burning of Oil Spills: Mesoscale Experiments", Proceedings of the Fifteenth Arctic and Marine Oil Spill Program Technical Seminar, June 10-12, 1992, Edmonton, Alberta, pp. 593-657.

[2] Walton, W.D. et al., "In-Situ Burning of Oil Spills: Mesoscale Experiments and Analysis", Proceedings of the Sixteenth Arctic and Marine Oil Spill Program Technical Seminar, June 7-9, 1993, Calgary, Alberta, pp. 679-734.

[3] Mulholland, G. "Smoke Production and Properties" The SFPE Handbook of Fire Protection Engineering, National Fire Protection Association, Quincy, MA, 1988.

[4] Holman, J.P., Experimental Methods for Engineers, McGraw-Hill, New York, 1989.

[5] Taylor, B.N., and Kuyatt, C.E., "Guidelines for Evaluating and Expressing the Uncertainty of NIST Measurement Results," NIST Technical Note 1297, 1993.

[6] Huggett, C., "Estimation of Rate and Heat Release by Means of Oxygen Consumption Measurements", Fire and Materials, 4, pp. 61-65, 1980.

[7] Operating Instructions, DMA 35, Anton Paar KG., Kärntner Strasse 322, Austria.

[8] Whiticar, S., et al., "A Catalogue of Crude Oil and Oil Product Properties", Environment Canada, Ottawa, Ontario, K1A OH3. Publication EE-144, 1992 edition, February 1993.

[9] Evans, D.D. et al., "Combustion of Oil on Water", National Bureau of Standards Report, NBSIR 86-3420, June 1986.

[10] Mulholland, G., Henzel, V., Babrauskas V., "The Effect of Scale on Smoke Emission", Fire Safety Science - Proceedings of the Second International Symposium, June 13-17, 1988, Tokyo, Japan, Hemisphere Publishing Corporation, New York, pp. 347-357.

[11] Hering, S.V. (ed.), Air Sampling Instruments, (7th ed.) American Conference of Governmental Industrial Hygienists, Cincinnati, Ohio, 1989.

[12] Koseki, H. and Yumoto, T., "Air Entrainment and Thermal Radiation from Heptane Pool Fires", Fire Technology, February, 1988.

[13] Title 18, Alaska Administrative Code, Chapter 50, Citation 20 (AAC 50.020) Ambient Air Quality Standards.

[14] Draxler, R.R., "Determination of Atmospheric Diffusion Parameters", Atmospheric Environment 10, 1976, pp. 95-105. 
[15] Pasquill, F.A. Atmospheric Diffusion, (2nd ed.), Halstead Press-Wiley, New York, 1974.

[16] Slade, D.H. (ed.) Meteorology and Atomic Energy, 1968, Air Resources Laboratory, Environmental Science Services Administration, United States Department of Commerce, July, 1968. (Available through National Technical Information Service (NTIS), Department of Commerce, TID-24190) 


\section{APPENDIX: LES PLUME TRAJECTORY MODEL RESULTS}

On the following pages we present the results of simulations of possible burns off both the northern and southern coasts of Alaska. These results have been summarized in Table 9. The temperature profiles were provided by the National Weather Service office in Alaska, and represent typical conditions of the winter and summer months. For each case we plot the vertical temperature profile, along with plots of the crosswind and downwind spread of the particulate matter. We focus our attention on particulate concentrations of 150 and $300 \mu \mathrm{g} / \mathrm{m}^{3}$ averaged over one hour. A concentration of $150 \mu \mathrm{g} / \mathrm{m}^{3}$ or higher averaged over 24 hours is considered hazardous to human health. The change in scale from one case to another reflects the fact that the wind speed, fire size and temperature profile determine the scale heights for each individual case. Thus, it is important to note these changes in scale when comparing one case with another. A contour plot of the ground level concentration is provided to indicate the downwind and lateral spread of the particulate matter near the ground. A plot of the centerline ground concentration is also provided to aid in quantifying the contour plot. This is not a plot of ground deposition, but rather an hour-averaged airborne concentration of particulate matter in the first 10 or 20 meters of the atmosphere.

The cases shown generally correspond to weather conditions with moderate and slight levels of daytime incoming solar radiation. (See Table 8) Generally speaking, for the size fires that we are considering, wind speeds which are less than about $2 \mathrm{~m} / \mathrm{s}$ ( 4 knots) cannot satisfy the assumption that the prevailing wind be stronger the induced crosswinds. In any case, we have found that a 6-10 m/s (12-20 knots) wind in combination with stability classes $C$ and $D$ will produce the greatest downwind spread of particulate matter, and thus we focus our attention on this regime. Stability classes $A$ and $B$ are highly dispersive and generally do not yield high ground level concentrations beyond about a kilometer of the burn site. Classes $\mathrm{E}$ and $\mathrm{F}$ are considered night time conditions and are inappropriate for that reason and because the wind speeds considered are too high for their use (See Table 8). 


\section{COOK INLET, SUMMER}

WIND SPEED $4.0 \mathrm{~m} / \mathrm{s}$

(A) TEMPERATURE PROFLLE

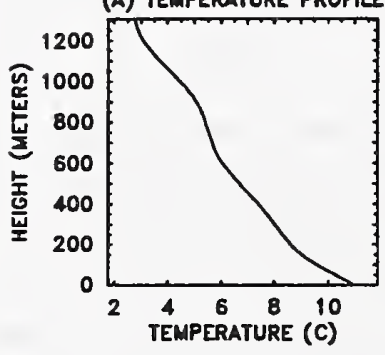

(B) CROSSWINO CONCENTRATION AT 5000. METERS

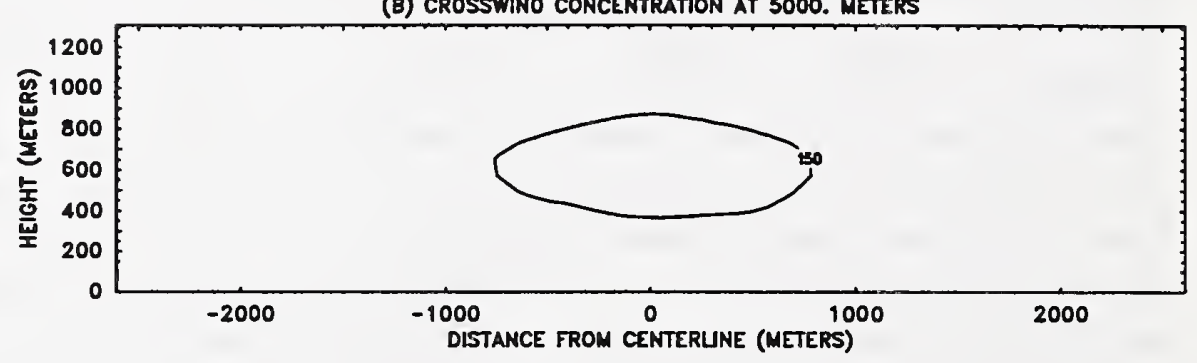

(C) VERTICAL CENTERUNE CONCENTRATION

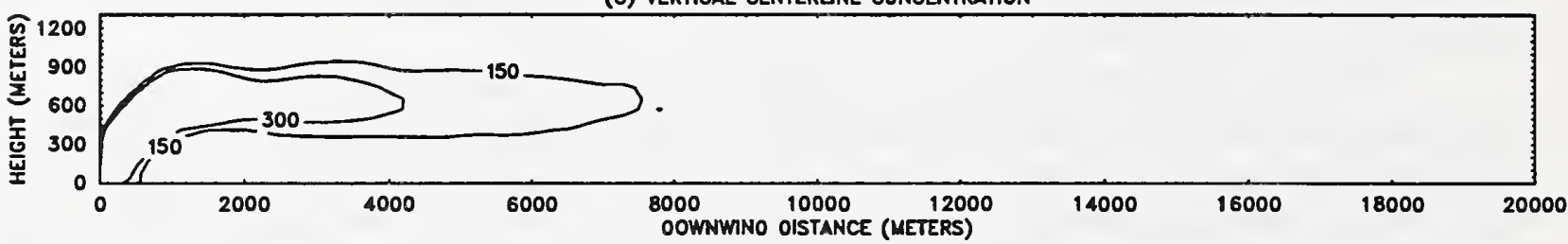

(D) GROUNO LEVEL CONCENTRATION

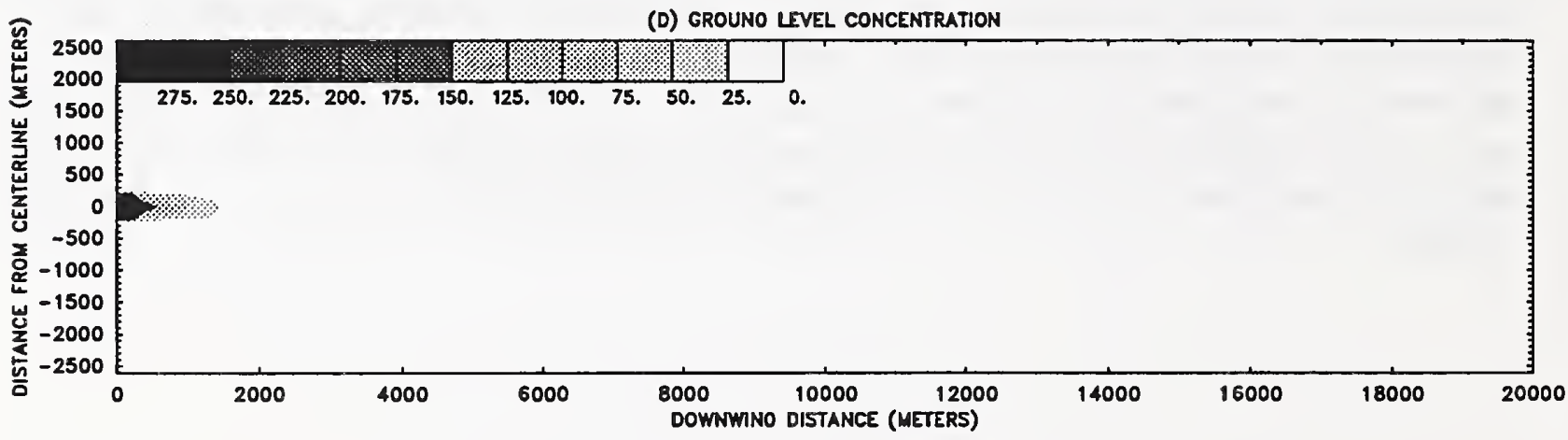

(E) GROUNO CENTERLNE CONCENTRATION

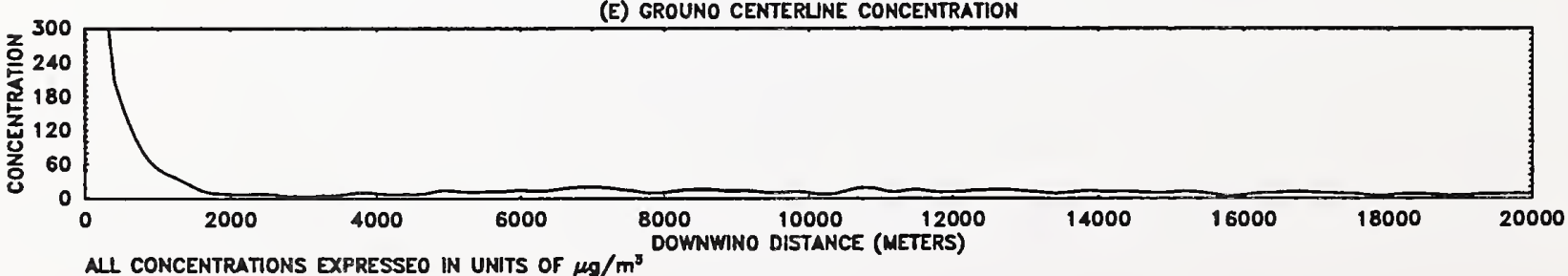

Figure 14 
COOK INLET, SUMMER

WIND SPEED $8.0 \mathrm{~m} / \mathrm{s}$

STABIUTY CLASS D

HEAT LOADING 450. MW

MASS LOADING $1.2 \mathrm{~kg} / \mathrm{s}$

(A) TEMPERATURE PROFLE

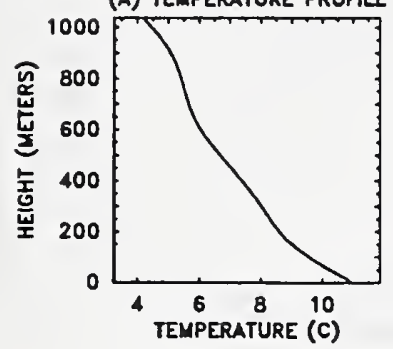

(B) CROSSWINO CONCENTRATION AT 5000. METERS

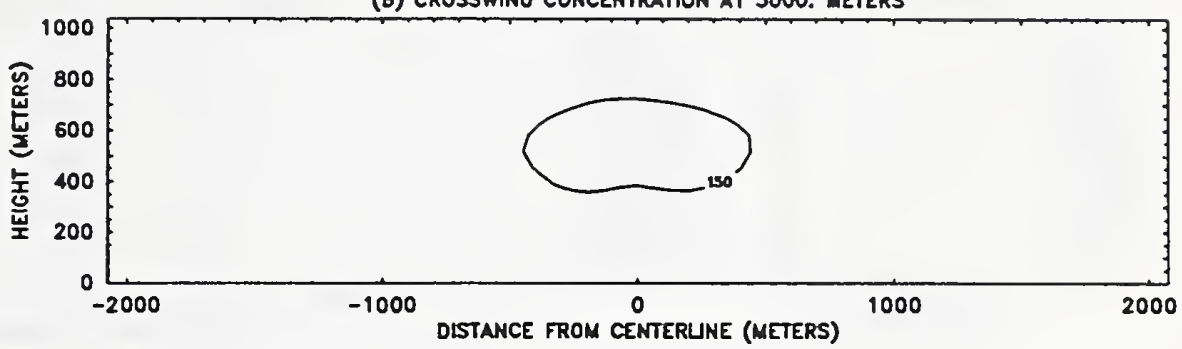

(C) VERTICAL CENTERUNE CONCENTRATION

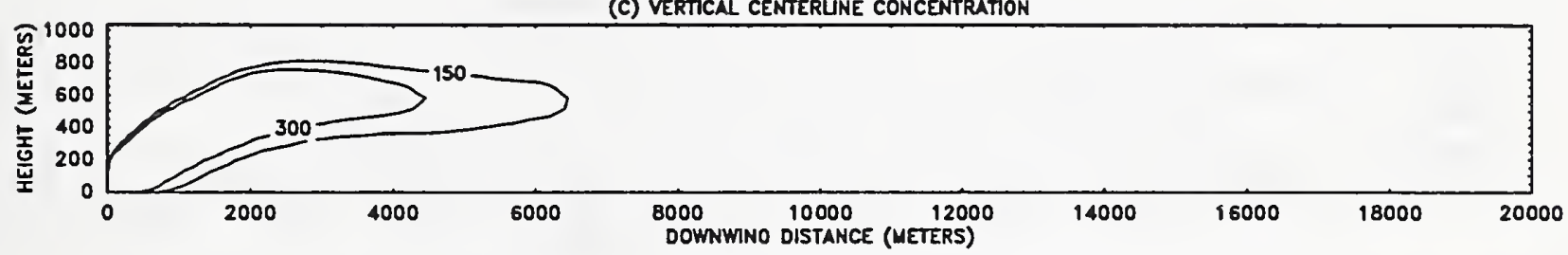

(D) GROUND LEVEL CONCENTRATION

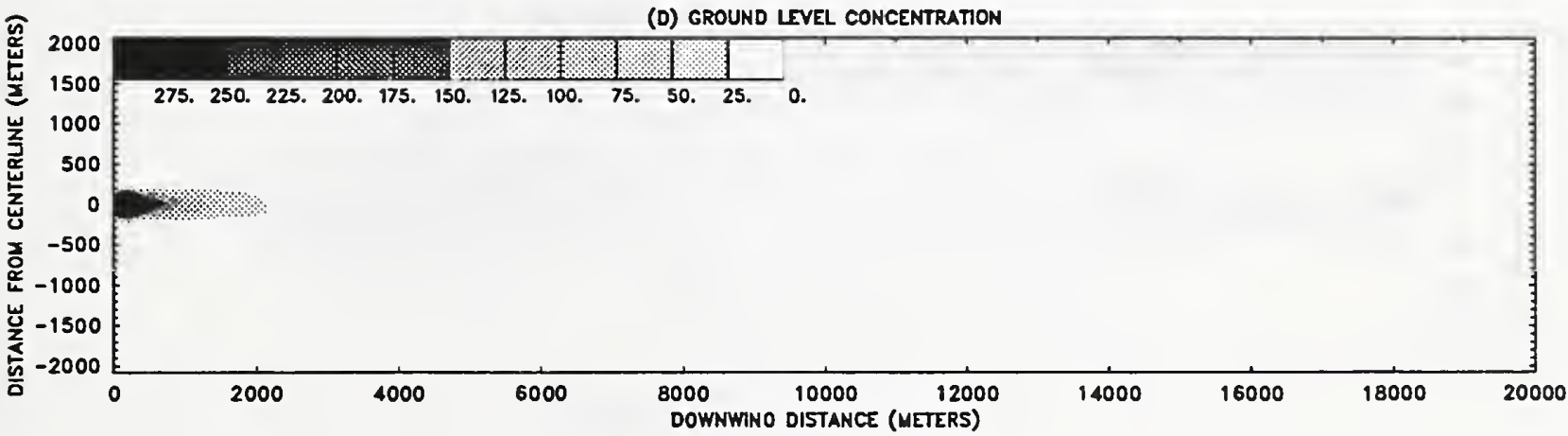

(E) GROUND CENTERUNE CONCENTRATION

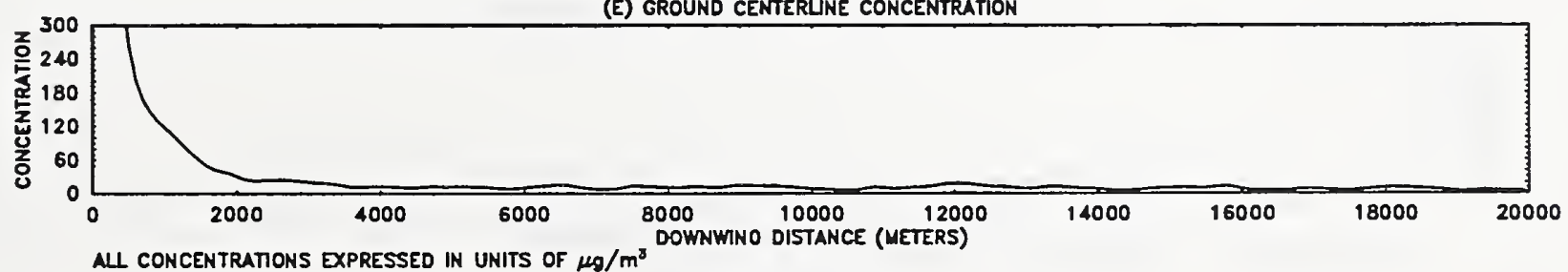

Figure 15 
WIND SPEED $12.0 \mathrm{~m} / \mathrm{s}$ STABILITY CLASS D
HEAT LOADING 450. MW MASS LOADING $1.2 \mathrm{~kg} / \mathrm{s}$

(A) TEMPERATURE PROTLE
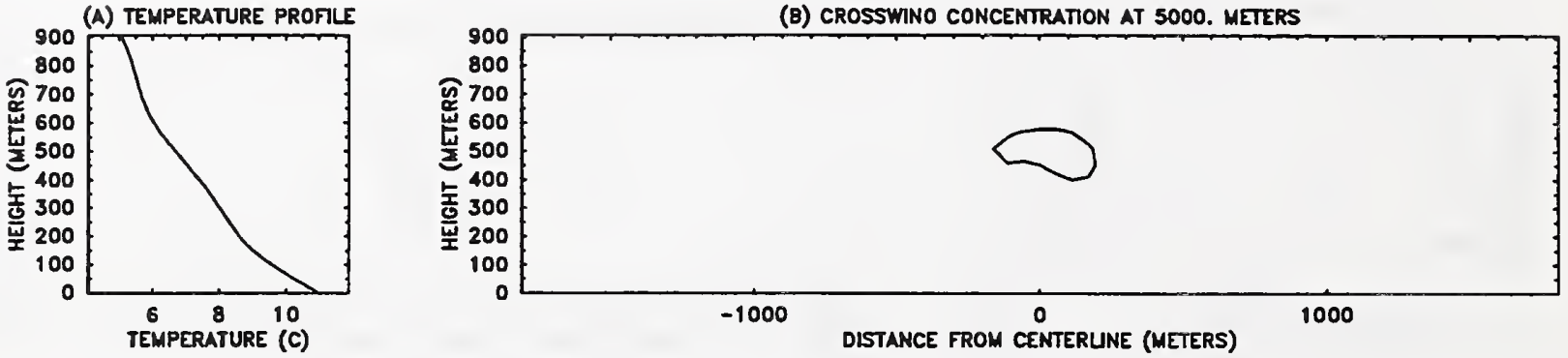

(c) VERTICAL CENTERUNE CONCENTRATION

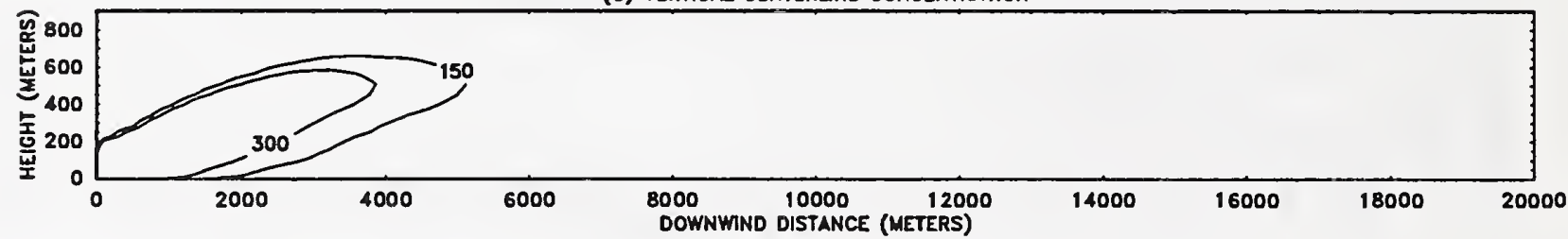

(0) GROUND LEVEL CONCENTRATION

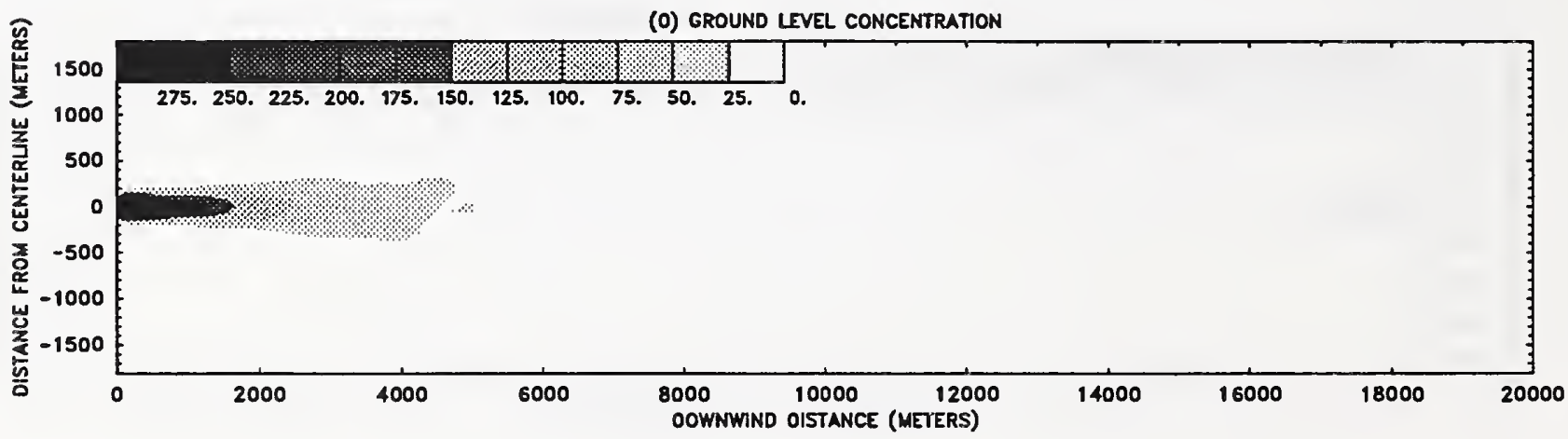

(E) GROUNO CENTERUNE CONCENTRATION

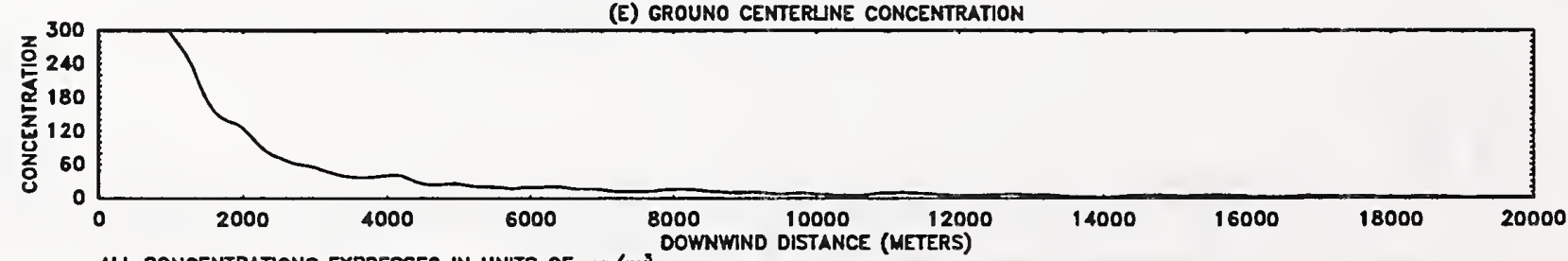
All CONCENTRATIONS EXPRESSEO IN UNITS OF $\mu \mathrm{g} / \mathrm{m}^{3}$

Figure 16 
COOK INLET, WINTER

WIND SPEED $4.0 \mathrm{~m} / \mathrm{s}$

HEAT LOADING 450. MW STABILITY CLASS C

MASS LOADING $1.2 \mathrm{~kg} / \mathrm{s}$

(A) TEMPERATURE PROFLE



(B) CROSSWINO CONCENTRATION AT 5000. METERS



(c) VERTICAL CENTERUNE CONCENTRATION

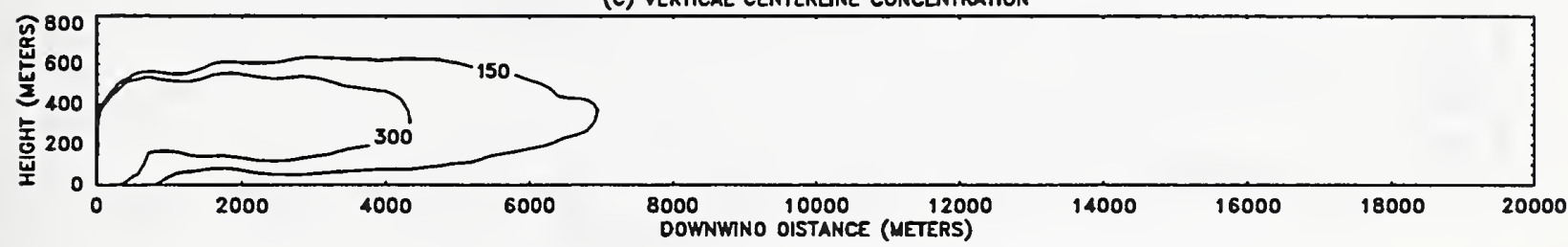

(D) GROUND LEVEL CONCENTRATION

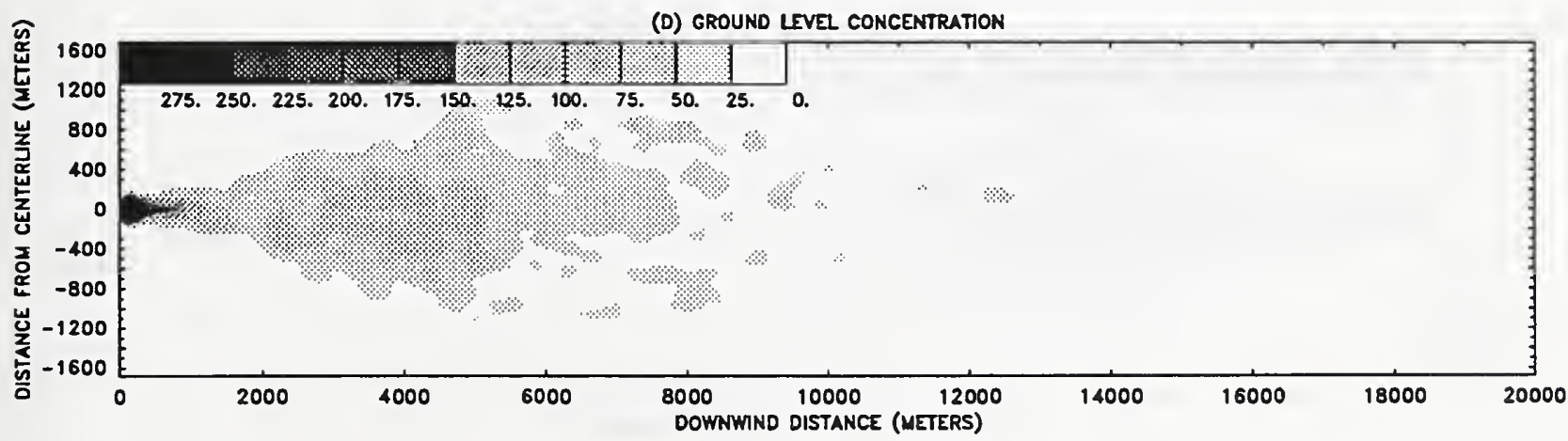

(E) GROUND CENTERUNE CONCENTRATION

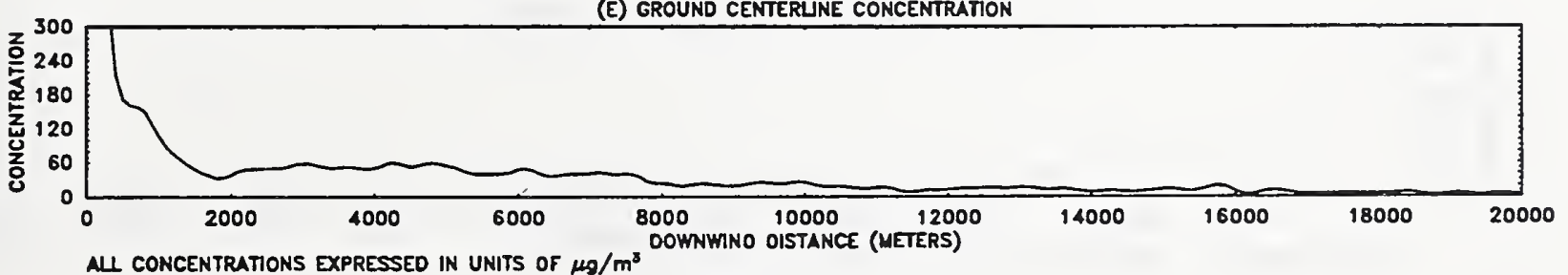

Figure 17 


\section{COOK INLET, WINTER}

(A) TEMPERATURE PROFLE

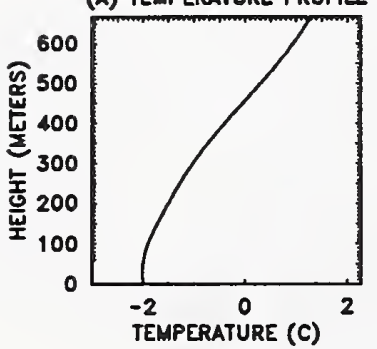

WIND SPEED $8.0 \mathrm{~m} / \mathrm{s}$ STABIUTY CLASS D
HEAT LOADING 450. MW MASS LOADING $1.2 \mathrm{~kg} / \mathrm{s}$

(B) CROSSWIND CONCENTRATION AT 5000. METERS

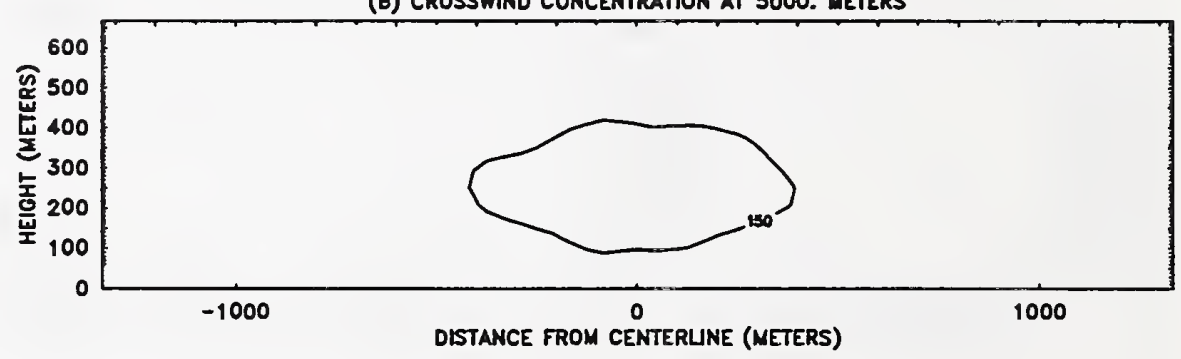

(C) VERTICAL CENTERLINE CONCENTRATION

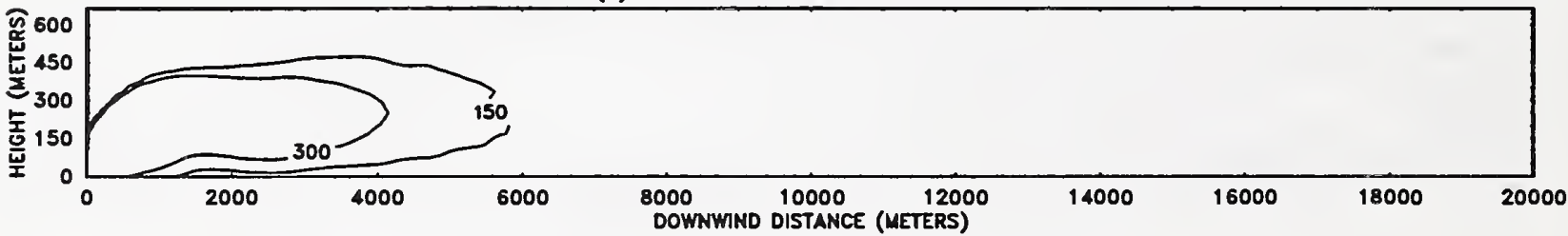

(D) GROUND LEVEL CONCENTRATION

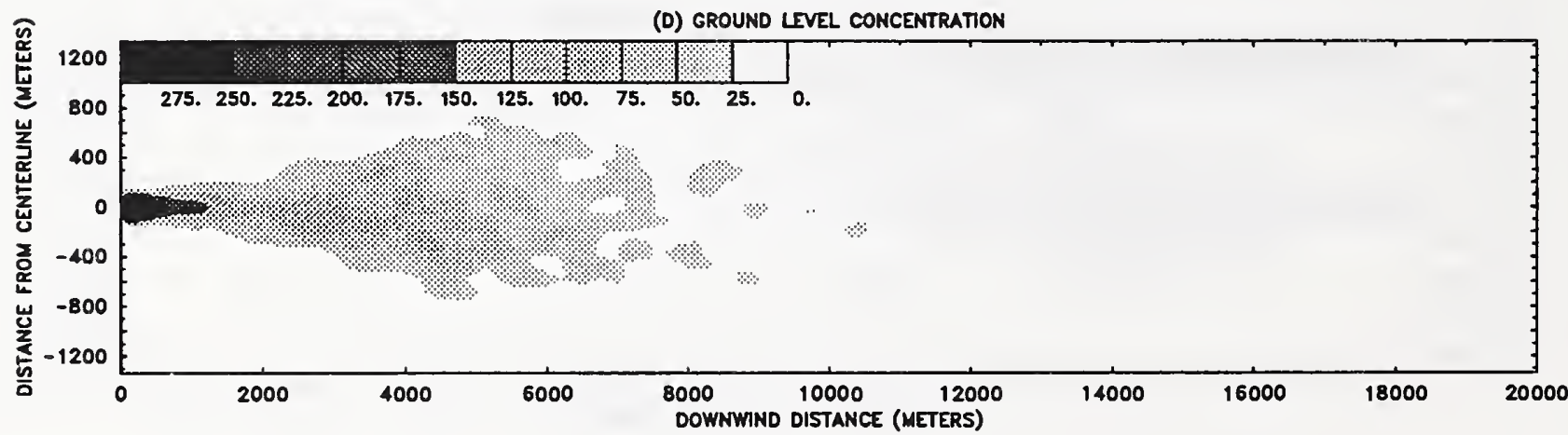

(E) GROUND CENTERLUNE CONCENTRATION

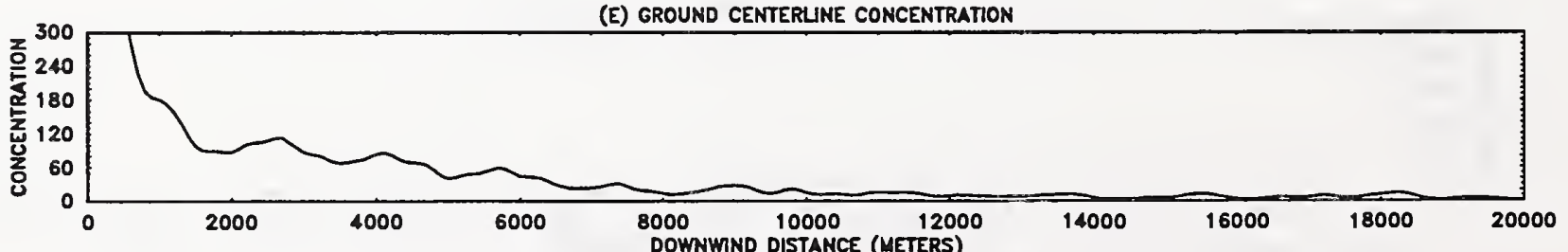

AL CONCENTRATIONS EXPRESSED IN UNITS OF $\mu g / \mathrm{m}^{3}$

Figure 18 
WIND SPEED $12.0 \mathrm{~m} / \mathrm{s}$

STABIUTY CLASS D
HEAT LOADING 450. MW

MASS LOADING $1.2 \mathrm{~kg} / \mathrm{s}$
(A) TEMPERATURE PROFILE

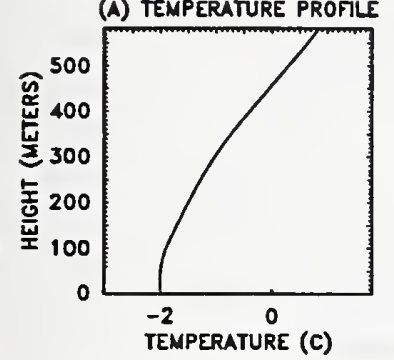

(B) CROSSWINO CONCENTRATION AT 5000. METERS

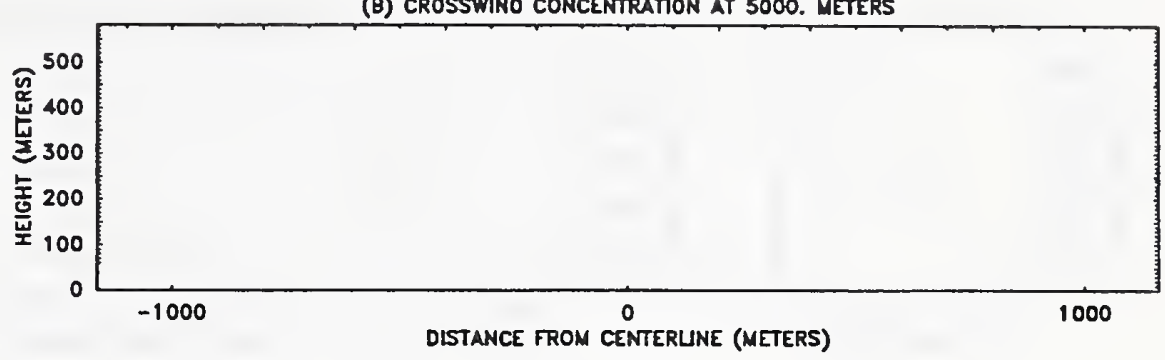

(C) VERTICAL CENTERUNE CONCENTRATION

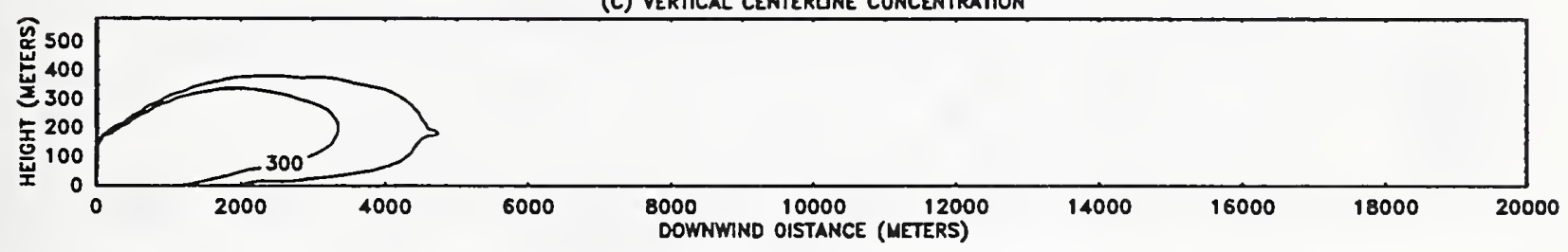

(0) GROUND LIVEL CONCENTRATION

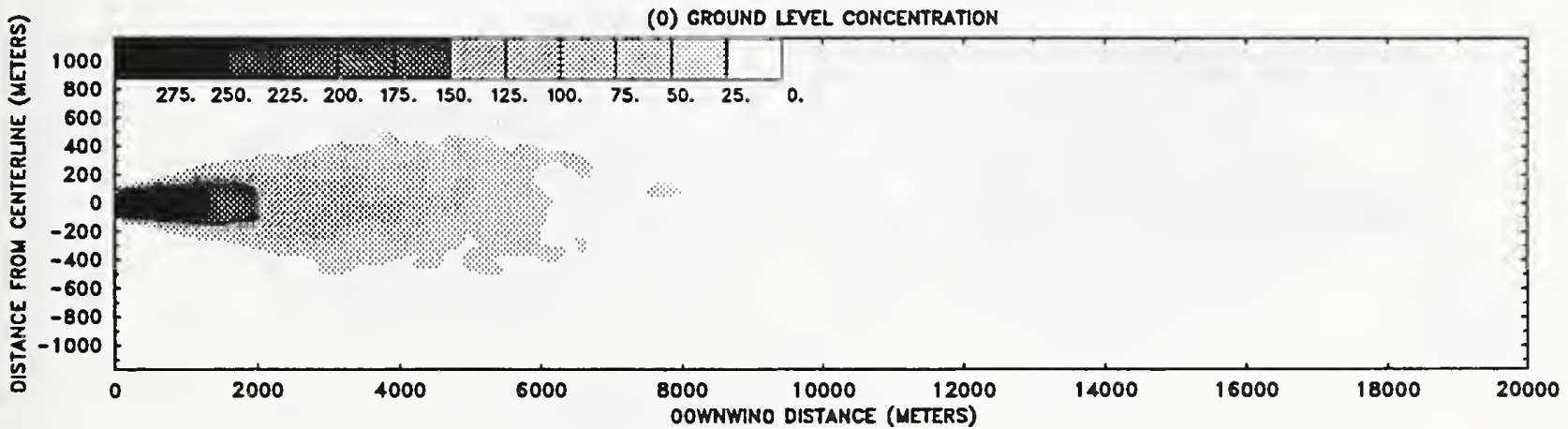

(E) GROUNO CENTERLINE CONCENTRATION

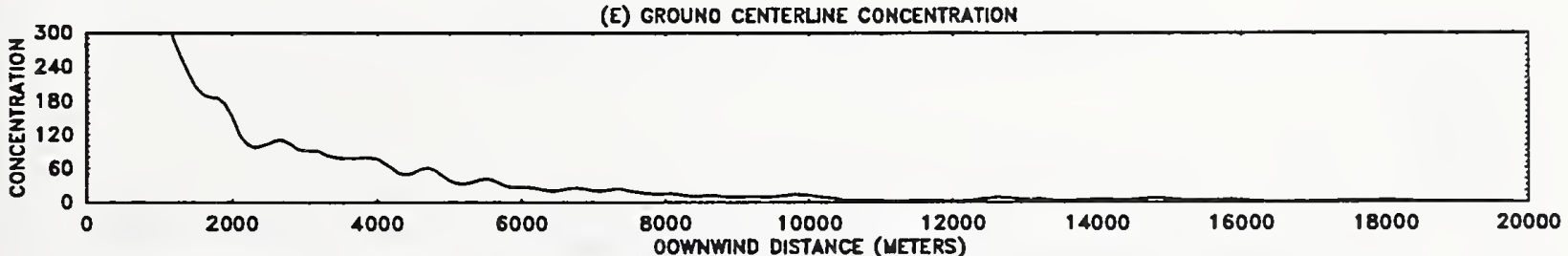

NL CONCENTRATIONS EXPRESSED IN UNITS OF $\mu \mathrm{g} / \mathrm{m}^{8}$

Figure 19 
(A) TEMPERATURE PROFILE



(B) CROSSWIND CONCENTRATION AT 5000. METERS

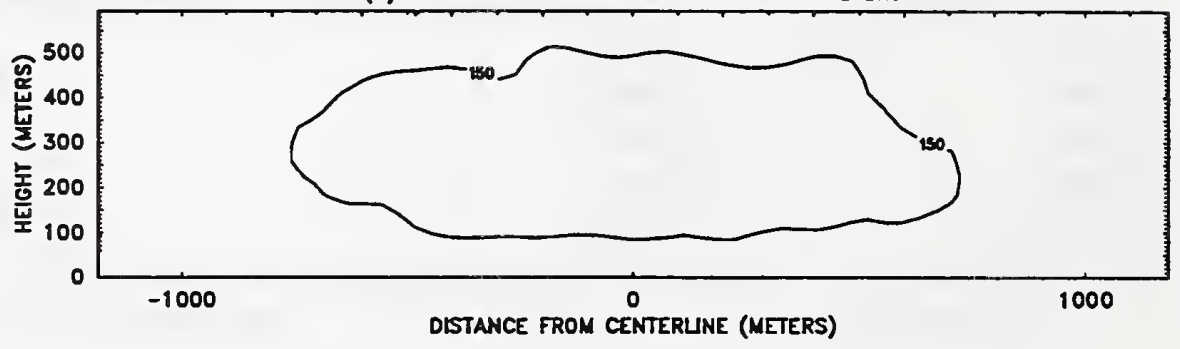

(C) VERTICAL CENTERUNE CONCENTRATION

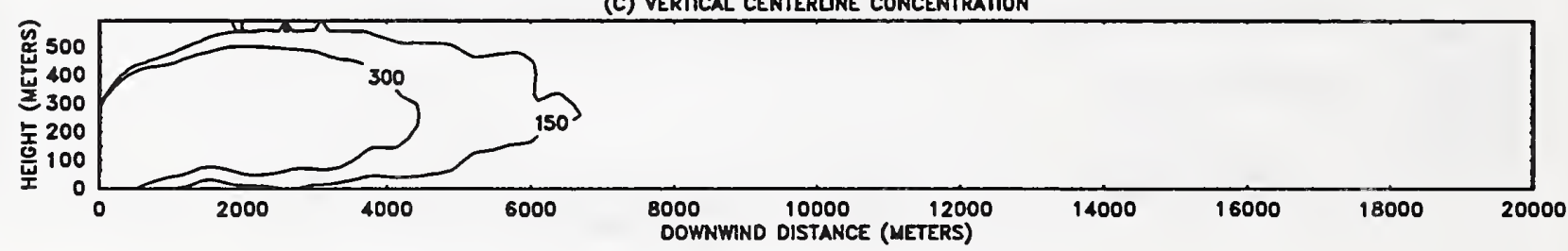

(0) GROUND LFVEL CONCENTRATION

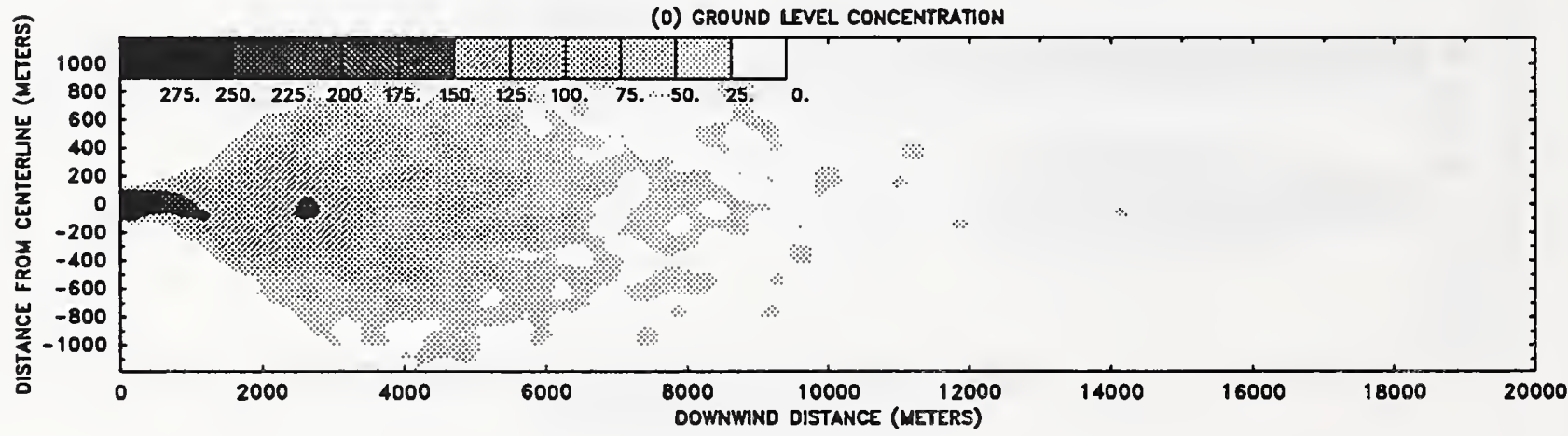

(E) GROUNO CENTERLNE CONCENTRATION

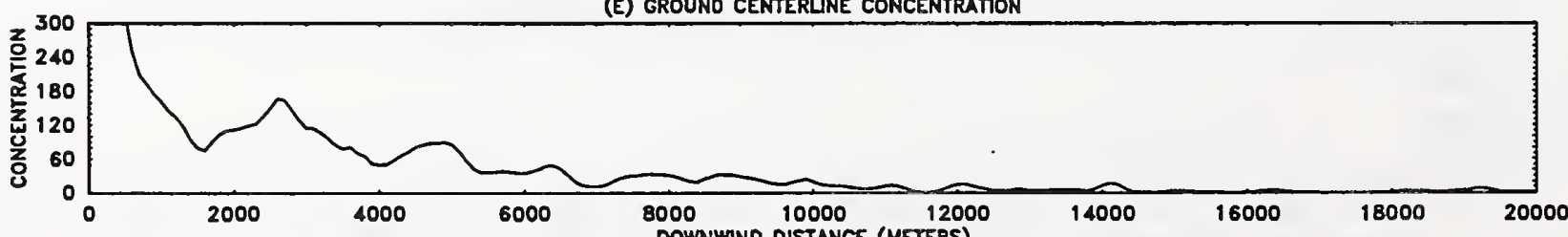
ALL CONCENTRATIONS EXPRESSED IN UNITS OF $\mu g / \mathrm{m}^{3}$

Figure 20 

NORTH SLOPE, SUMMER
WIND SPEED $8.0 \mathrm{~m} / \mathrm{s}$
HEAT LOADING 410. MW STABILTY CLASS D
MASS LOADING $1.4 \mathrm{~kg} / \mathrm{s}$

(A) TEMPERATURE PROFILF

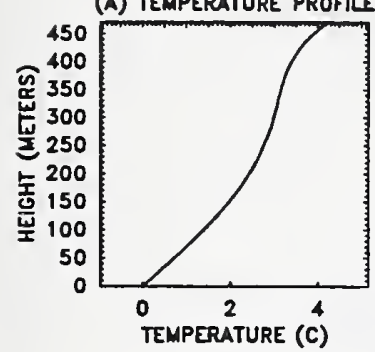

(B) CROSSWINO CONCENTRATION AT 5000. METERS

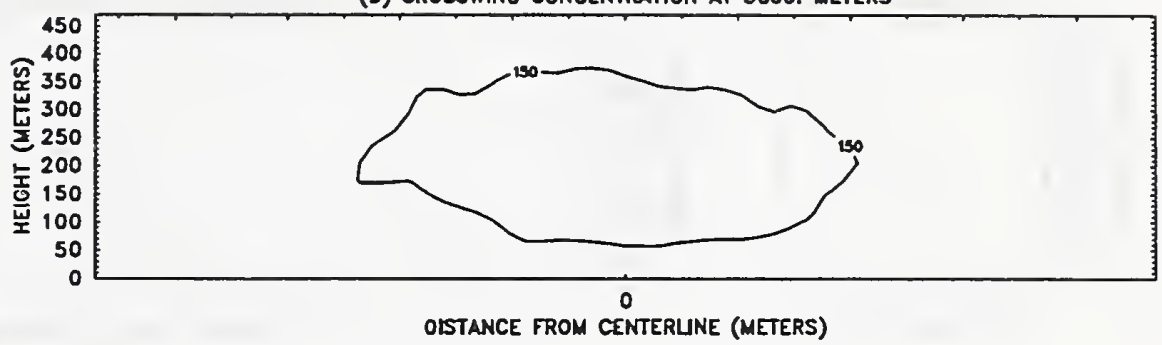

(C) VERTICAL CENTERUNE CONCENTRATION

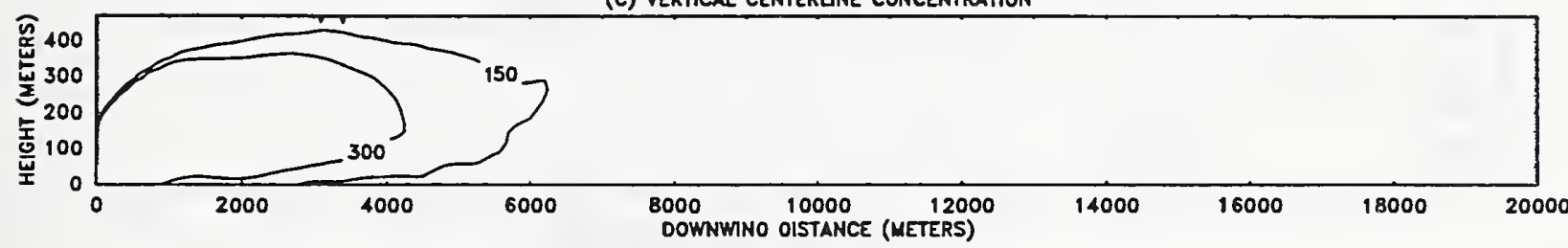

(0) GROUND LEVEL CONCENTRATION

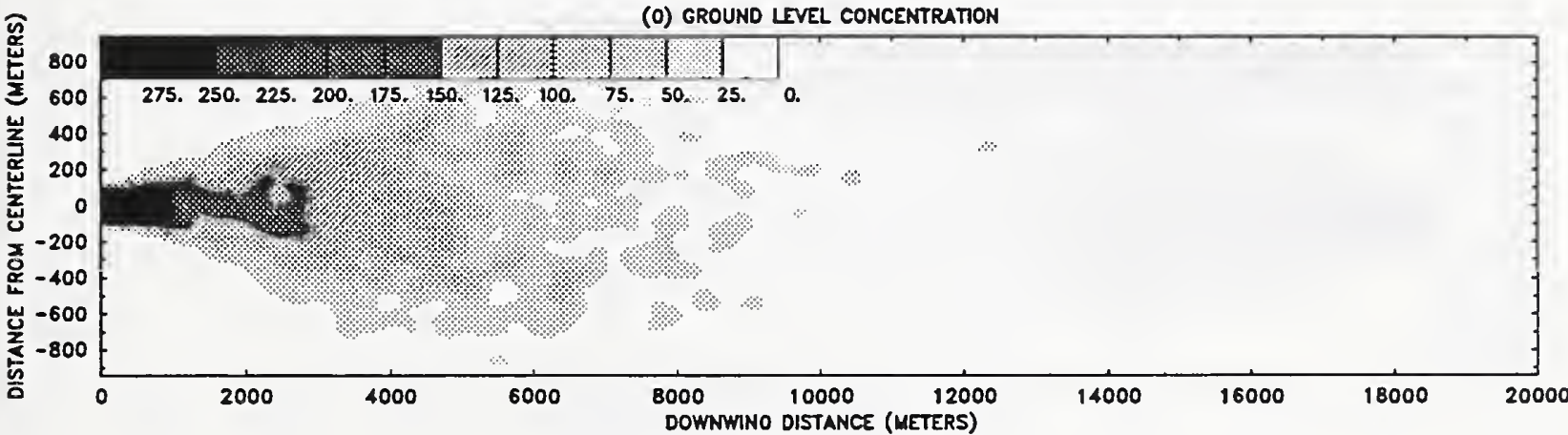

(E) GROUND CENTERLINE CONCENTRATION

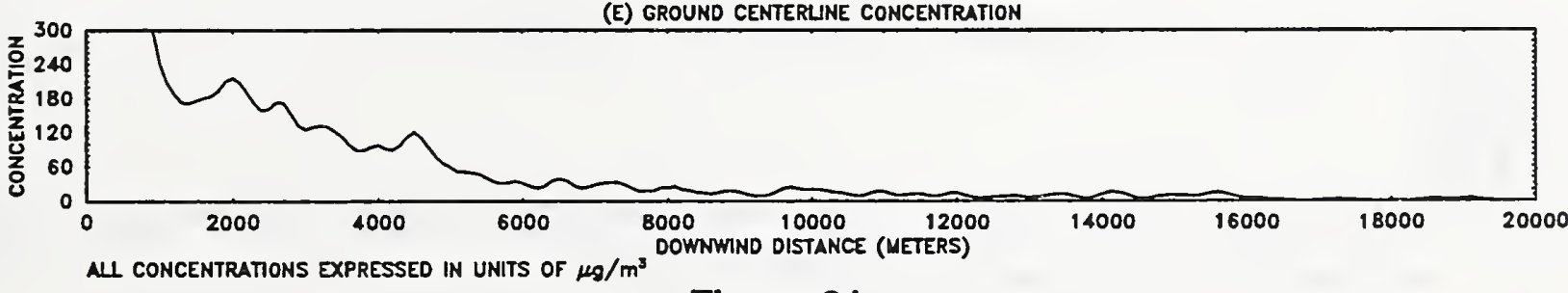

Figure 21 
NORTH SLOPE, SUMMER

(A) TEMPERATURE PROFILE

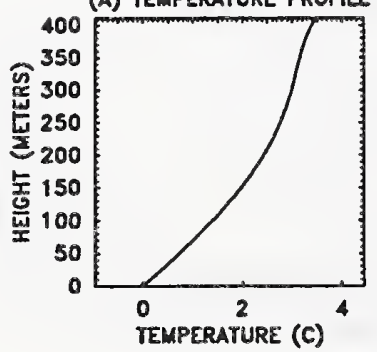

WIND SPEED $12.0 \mathrm{~m} / \mathrm{s}$ STABIUTY CLASS D
HEAT LOADING 410. NW

MASS LOADING $1.4 \mathrm{~kg} / \mathrm{s}$

(B) CROSSWIND CONCENTRATION AT SOO0. METERS

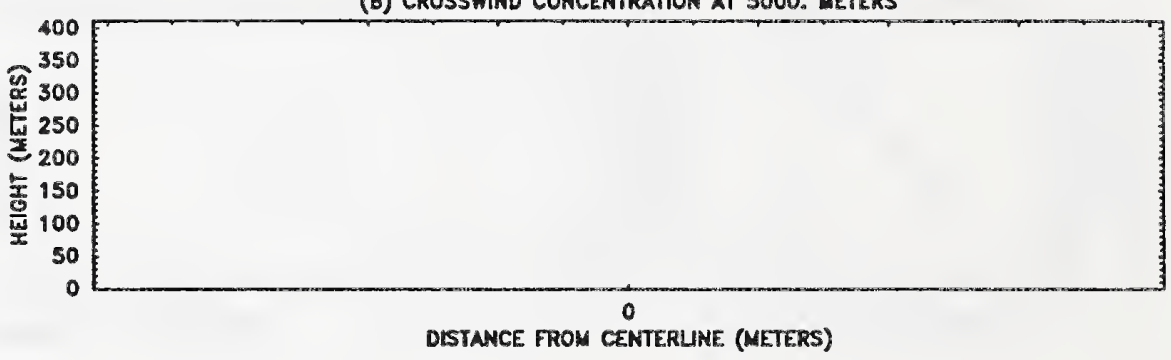

(C) VERTICAL CENTERUNE CONCENTRATION

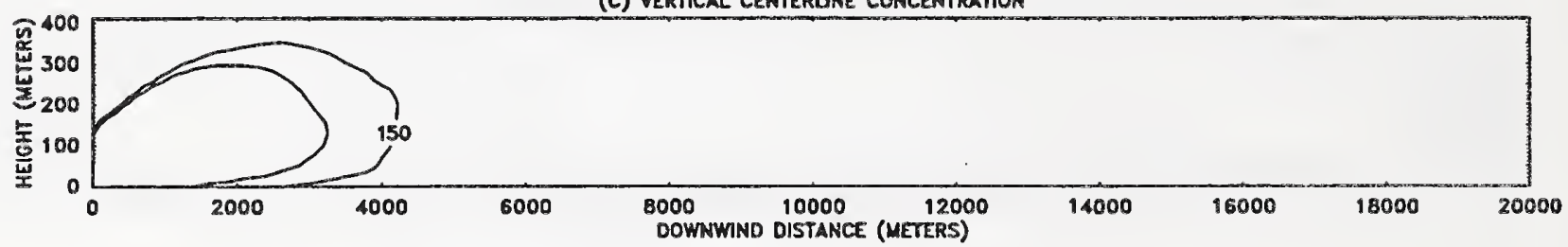

(D) GROUND LEVEL CONCENTRATION

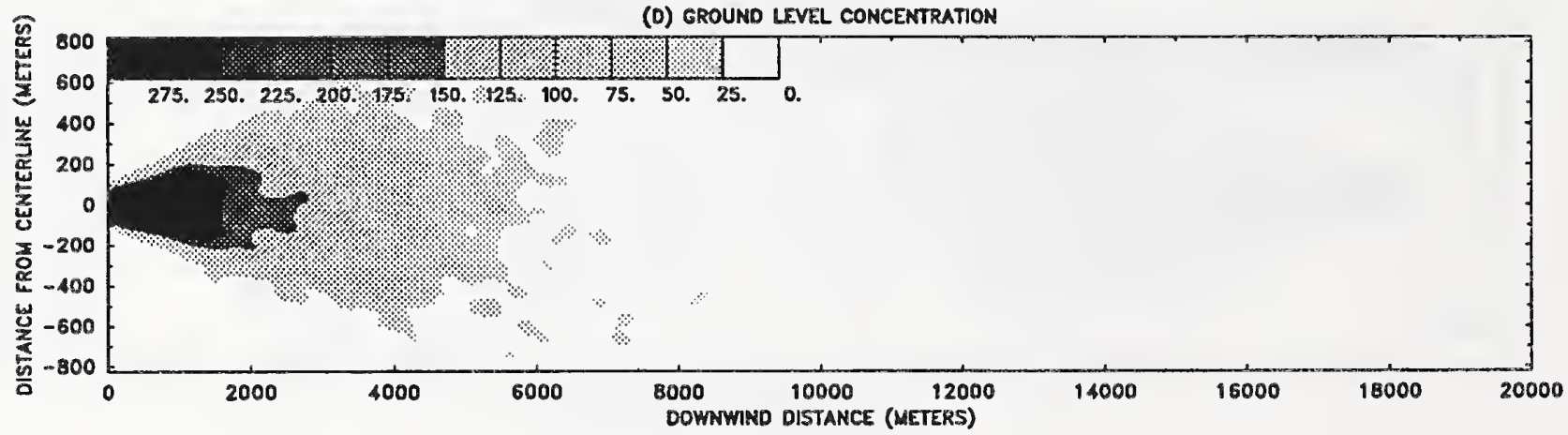

(E) GROUND CENTERLINE CONCENTRATION

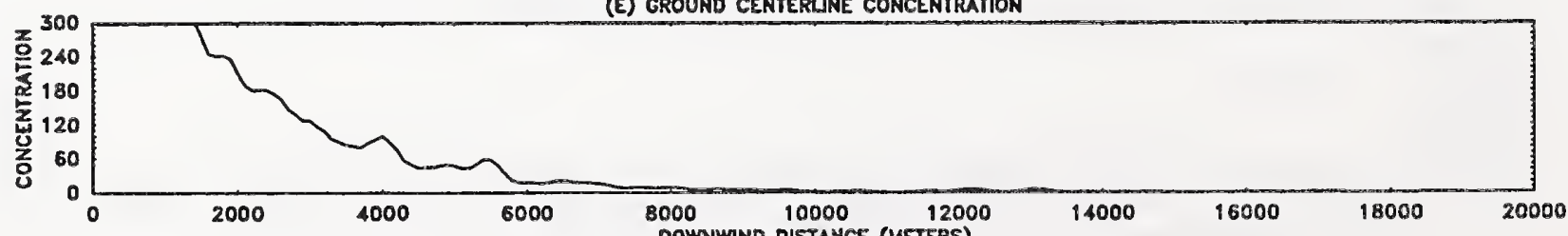

ALL CONCENTRATIONS EXPRESSED IN UNITS OF $\mu \mathrm{g} / \mathrm{m}^{3}$

Figure 22 
(A) TEMPERATURE PROFLE

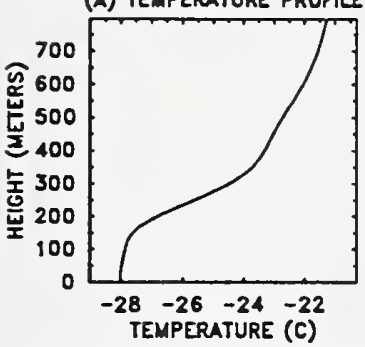

(B) CROSSWIND CONCENTRATION AT 5000. METERS

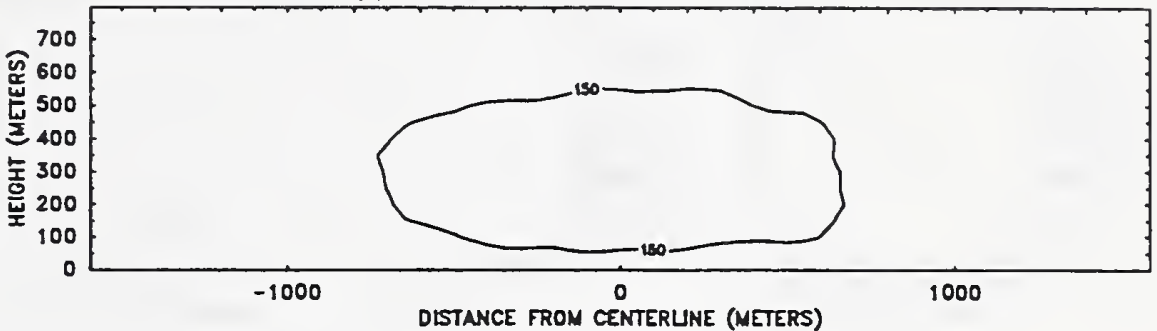

(C) VERTICAL CENTERUNE CONCENTRATION



(0) GROUND LEVEL CONCENTRATION

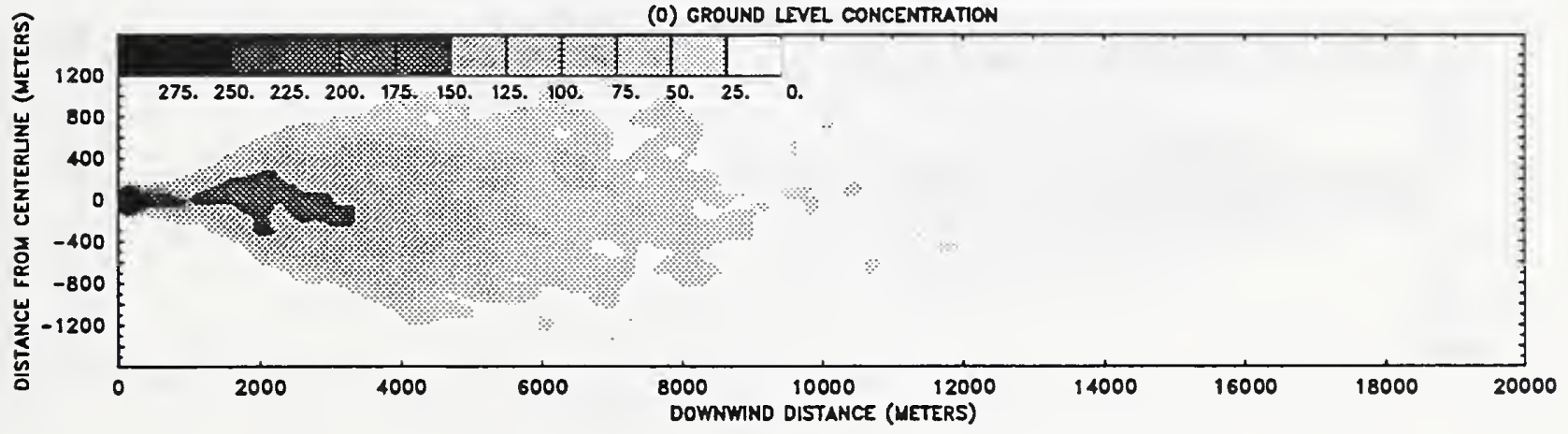

(E) GROUND CENTERLINE CONCENTRATION

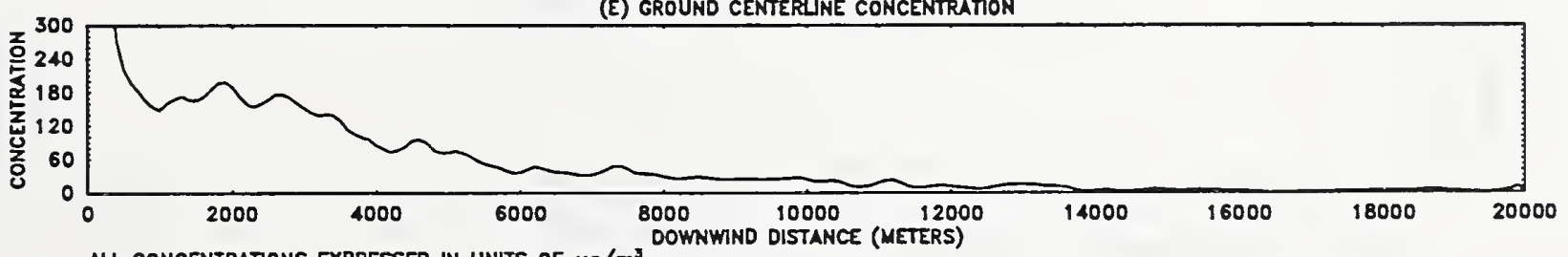
AL CONCENTRATIONS EXPRESSED IN UNITS OF $\mu \mathrm{g} / \mathrm{m}^{3}$

Figure 23 

NORTH SLOPE, WINTER
WIND SPEED $8.0 \mathrm{~m} / \mathrm{s}$
HEAT LOADING 410. MW
STABILITY CLASS D
MASS LOADING $1.4 \mathrm{~kg} / \mathrm{s}$

(A) TEMPERATURE PROFILE

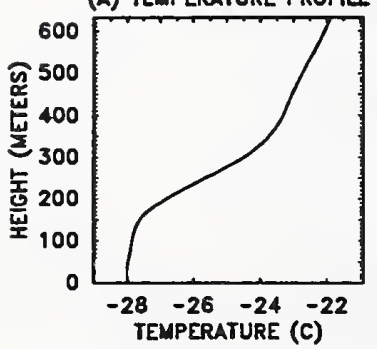

(B) CROSSWINO CONCENTRATION AT 5000. METERS

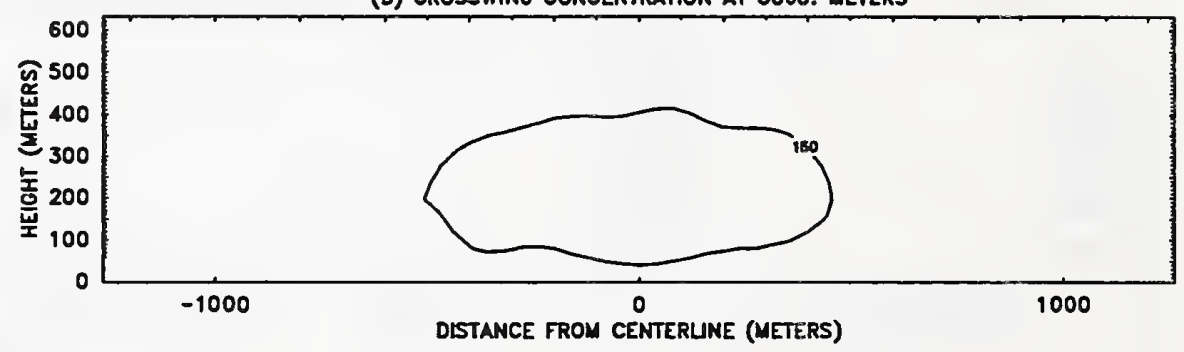

(C) VERTICAL CENTERUNE CONCENTRATION

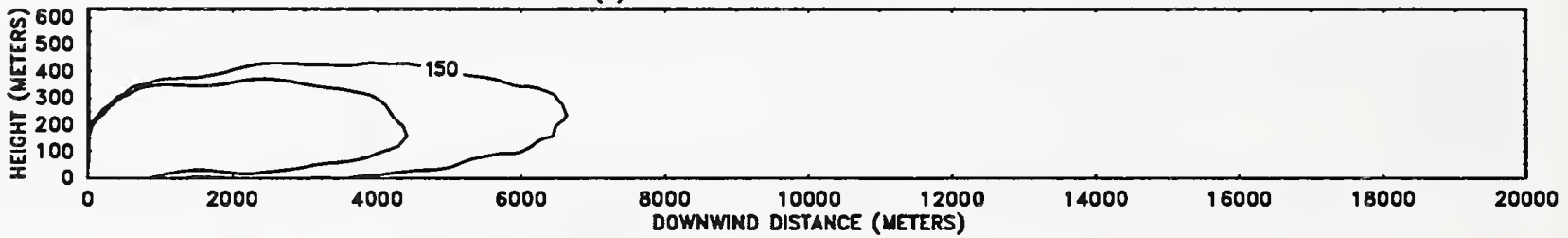

(D) GROUND LEVEL CONCENTRATION

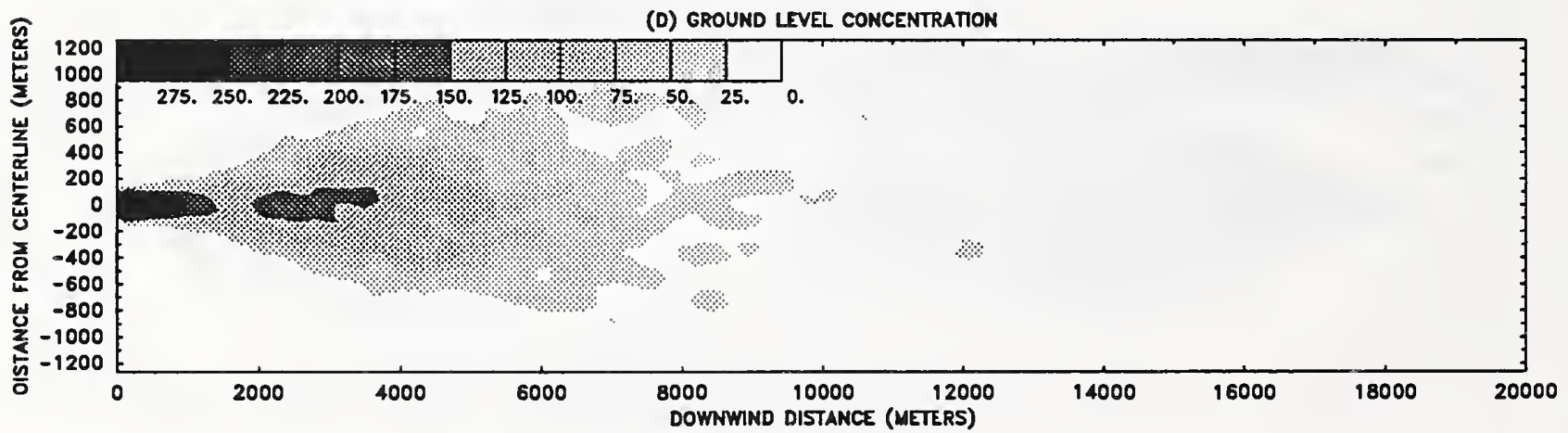

(E) GROUNO CENTERUME CONCENTRATION

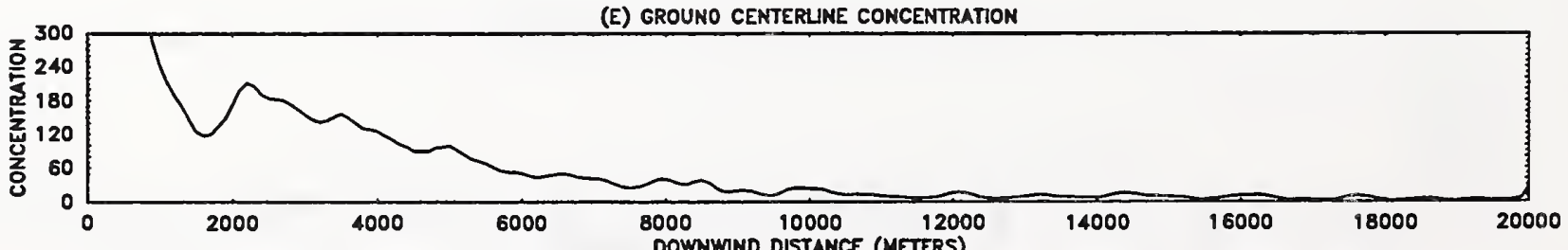

ALL CONCENTRATIONS EXPRESSEO IN UNITS OF $\mu \mathrm{g} / \mathrm{m}^{3}$

Figure 24 
NORTH SLOPE, WINTER

(A) TEMPERATURE PROTLL

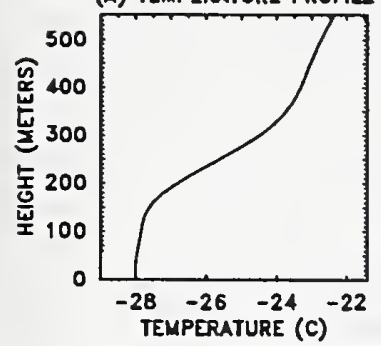

WIND SPEED $12.0 \mathrm{~m} / \mathrm{s}$

STABILITY CLASS D
HEAT LOADING 410. MW

MASS LOADING $1.4 \mathrm{~kg} / \mathrm{s}$

(B) CROSSWINO CONCENTRATION AT 5000. METERS

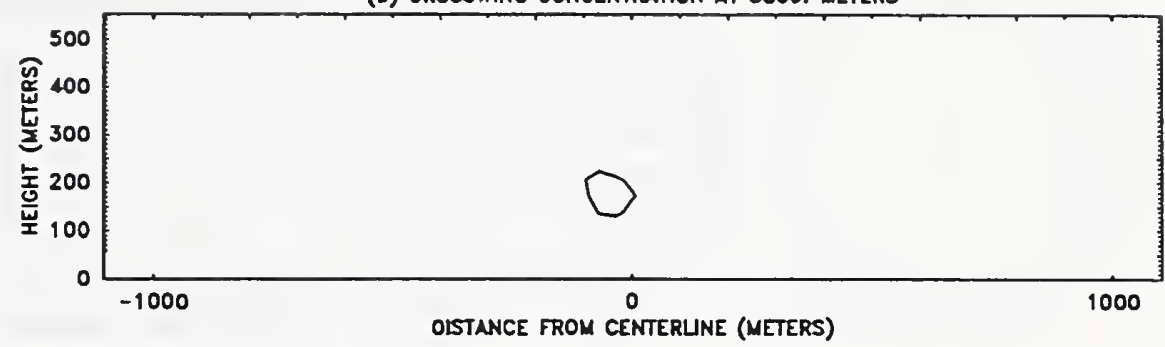

(C) VERTICAL CENTERUNE CONCENTRATION

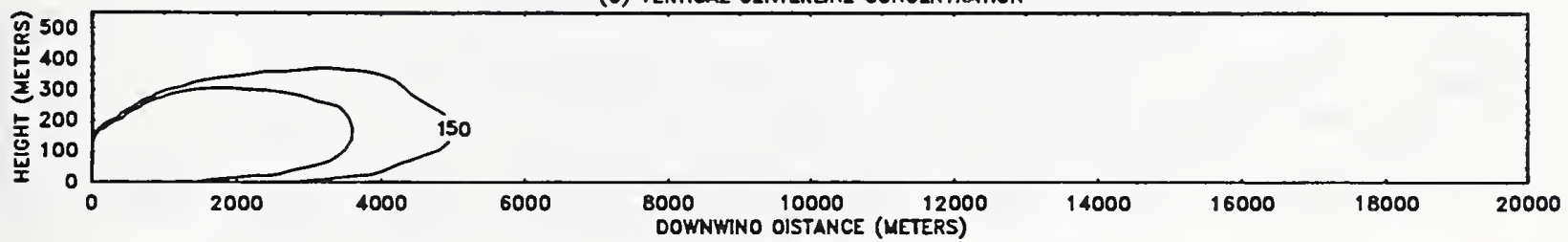

(0) GROUNO LEVEL CONCENTRATION

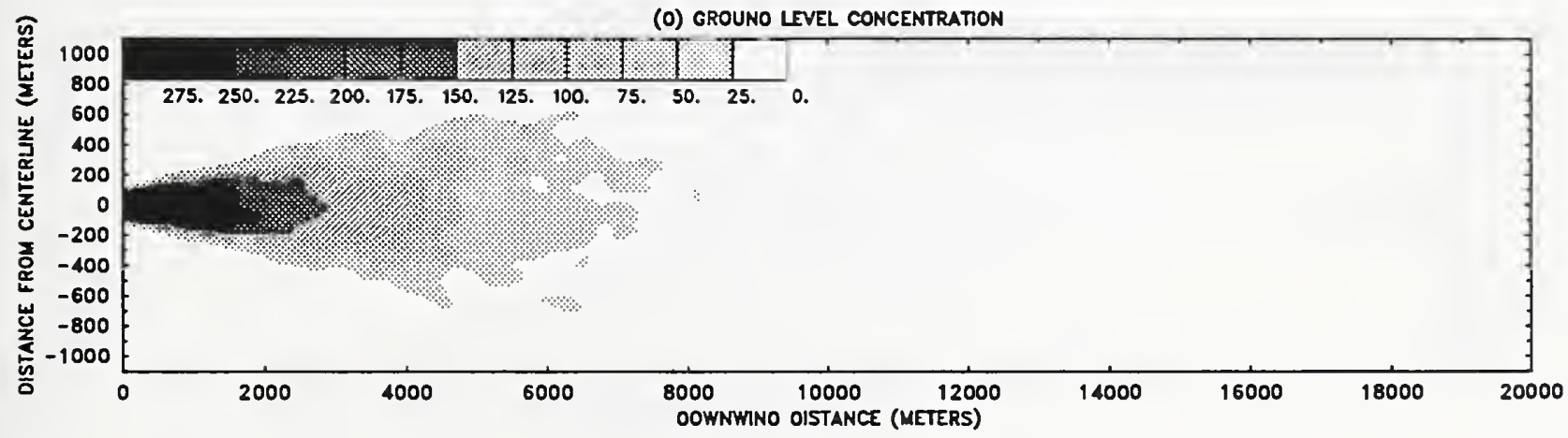

(E) GROUNO CENTERUNE CONCENTRATION

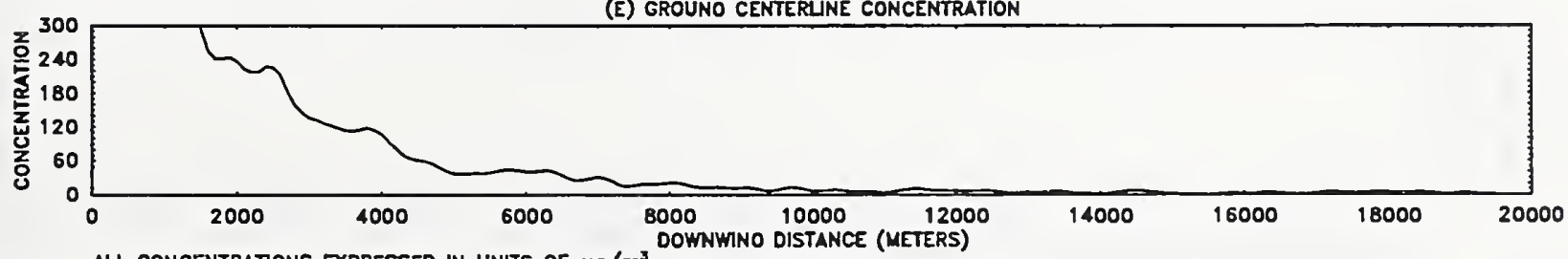

AL CONCENTRATIONS EXPRESSED IN UNITS OF $\mu \mathrm{g} / \mathrm{m}^{3}$

Figure 25 
COOK INLET, SUMMER

WIND SPEED $4.0 \mathrm{~m} / \mathrm{s}$

STABILITY CLASS C

HEAT LOADING 900. NW

MASS LOADING $2.4 \mathrm{~kg} / \mathrm{s}$

(A) TEMPERATURE PROTLE
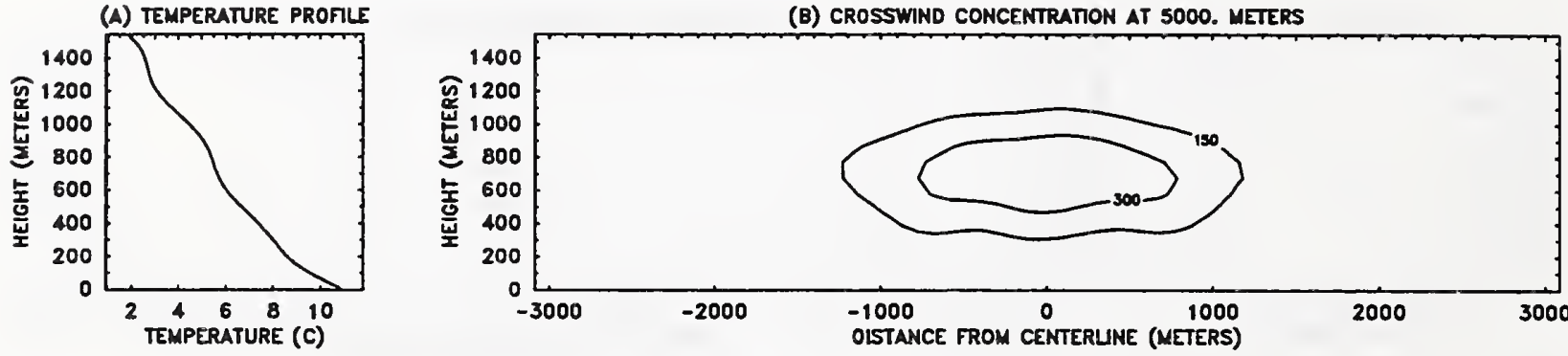

(C) VERTICAL CENTERLINE CONCENTRATION

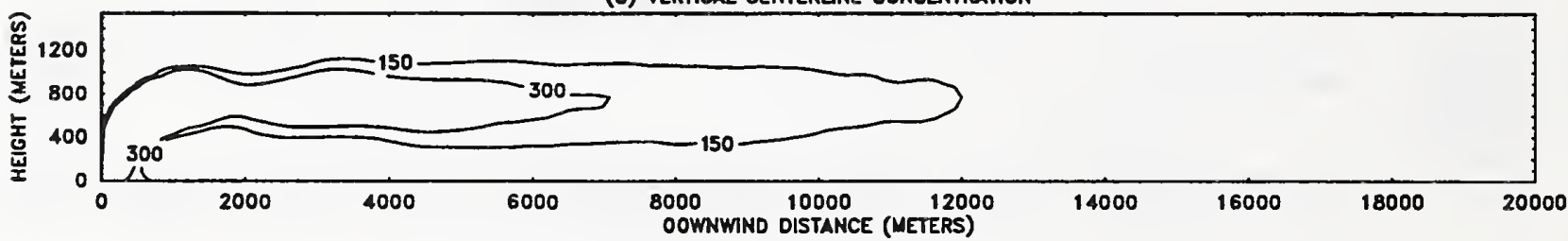

(D) GROUND LEVEL CONCENTRATION

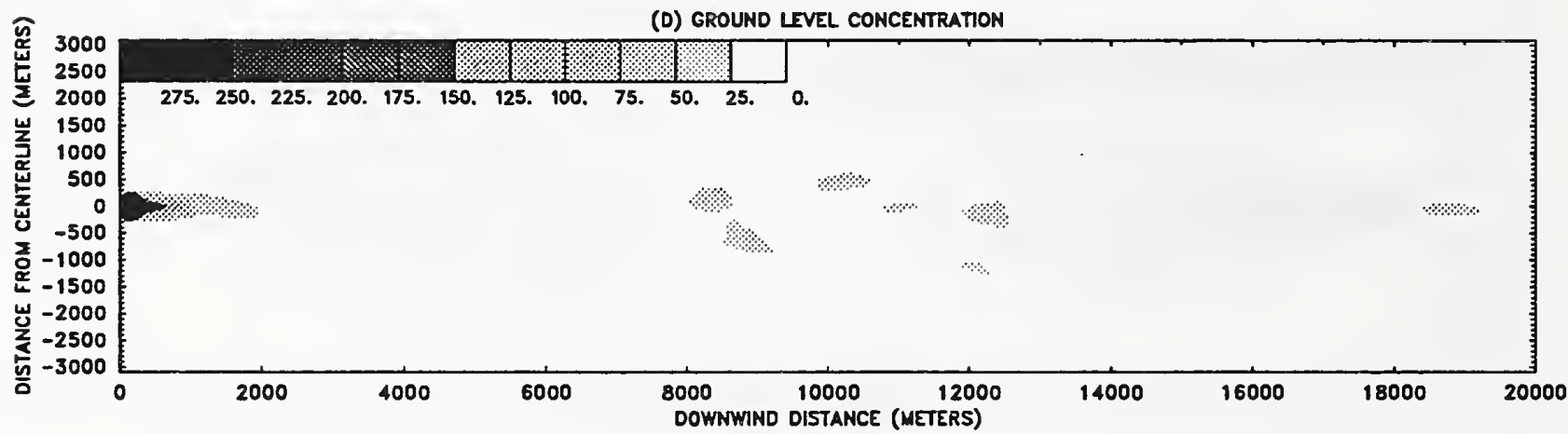

(E) GROUND CENTERUNE CONCENTRATION

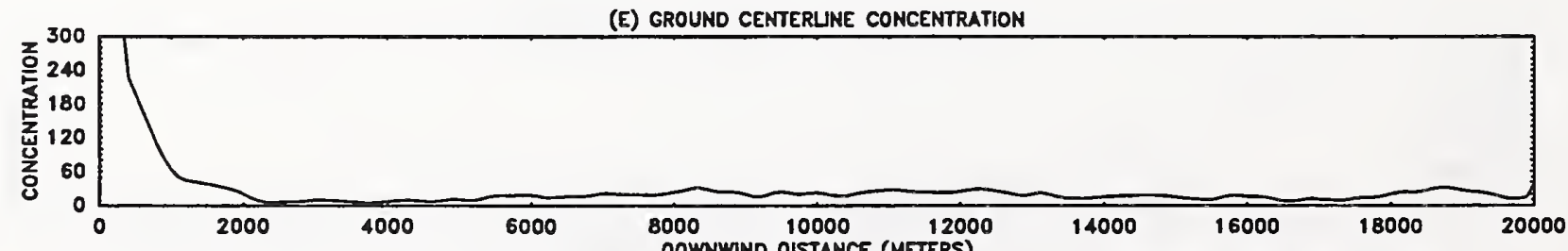

ALI CONCENTRATIONS EXPRESSED IN UNITS OF $\mu \mathrm{g} / \mathrm{m}^{3}$

Figure 26 
COOK INLET, SUMMER

WIND SPEED $8.0 \mathrm{~m} / \mathrm{s}$

HEAT LOADING 900. MW STABIUTY CLASS D

MASS LOADING $2.4 \mathrm{~kg} / \mathrm{s}$

(A) TEMPERATURE PROFLE

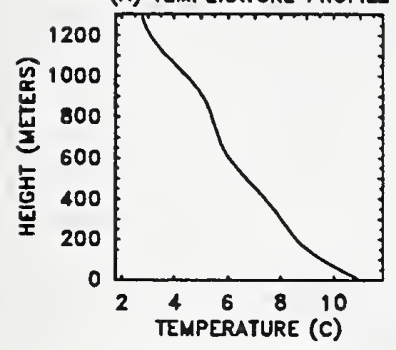

(B) CROSSWIND CONCENTRATION AT 5000. METERS

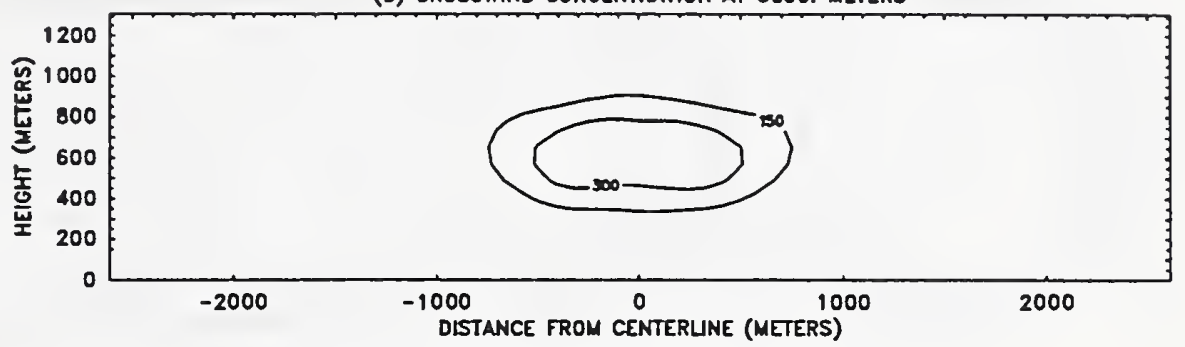

(C) VERTICAL CENTERLUNE CONCENTRATION

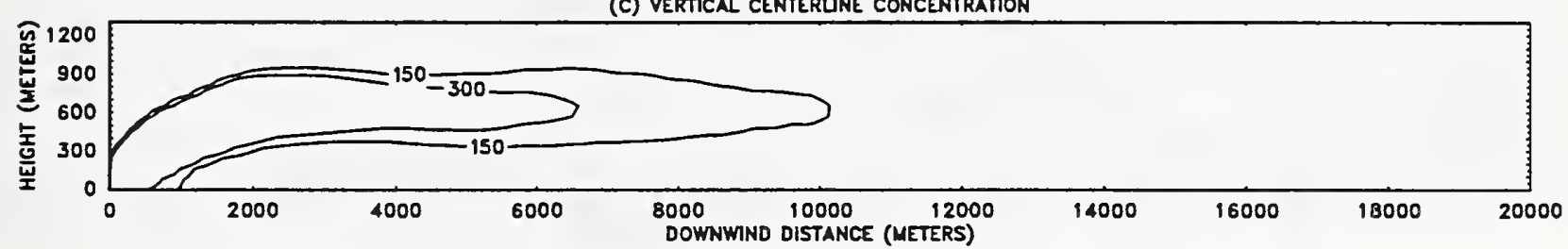

(D) GROUND LIVEL CONCENTRATION

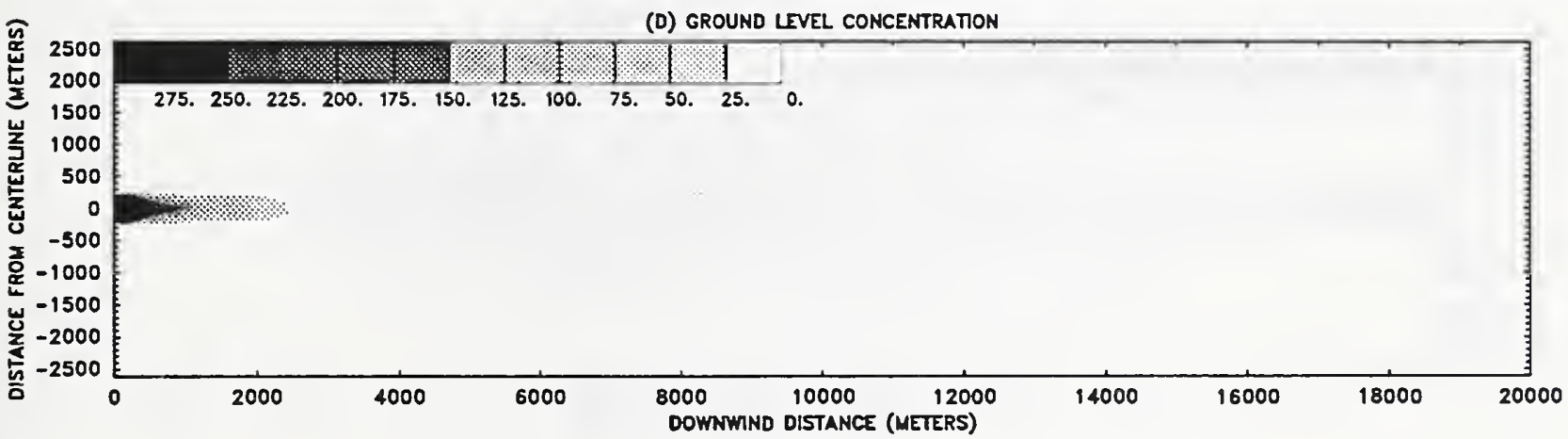

(E) GROUND CENTERUNE CONCENTRATION

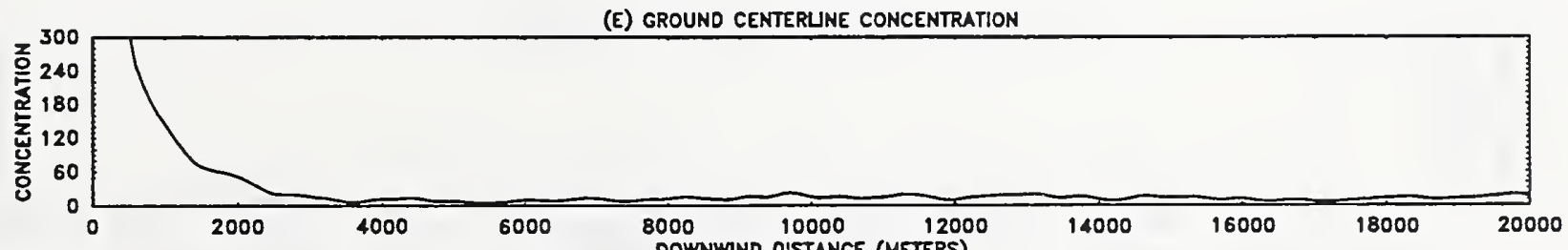

ALL CONCENTRATIONS EXPRESSED IN UNITS OF $\mu \mathrm{g} / \mathrm{m}^{3}$

Figure 27 
COOK INLET, SUMMER

WIND SPEED $12.0 \mathrm{~m} / \mathrm{s}$

HEAT LOADING 900. MW

STABIUTY CLASS D

MASS LOADING $2.4 \mathrm{~kg} / \mathrm{s}$

(A) TEMPERATURE PROTILE

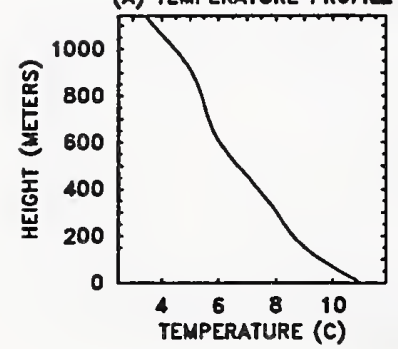

(B) CROSSWIND CONCENTRATION AT 5000. METERS

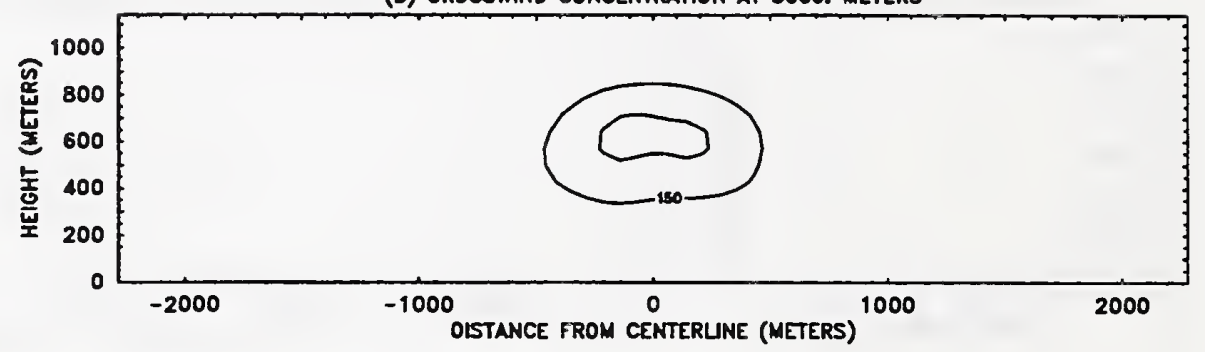

(C) VERTICAL CENTERLNE CONCENTRATION

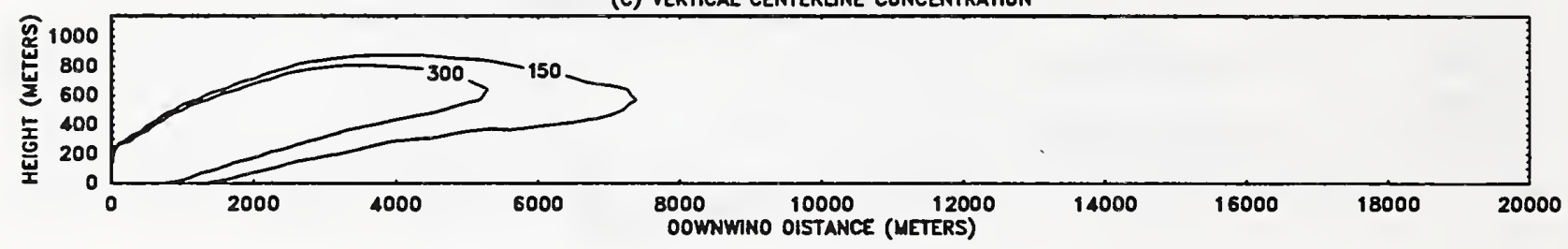

(D) GROUNO LEVEL CONCENTRATION



(E) GROUNO CENTERLINE CONCENTRATION



AL CONCENTRATIONS EXPRESSEO IN UNITS OF $\mu \mathrm{g} / \mathrm{m}^{8}$

Figure 28 


\section{COOK INLET, WINTER}

(A) TEMPERATURE PROFLE

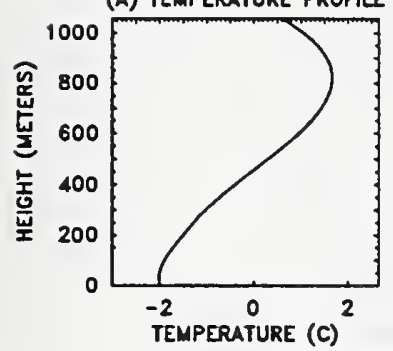

WIND SPEED $4.0 \mathrm{~m} / \mathrm{s}$ STABILITY CLASS C
HEAT LOADING 900. MW MASS LOADING $2.4 \mathrm{~kg} / \mathrm{s}$

(B) CROSSWIND CONCENTRATION AT 5000. METERS

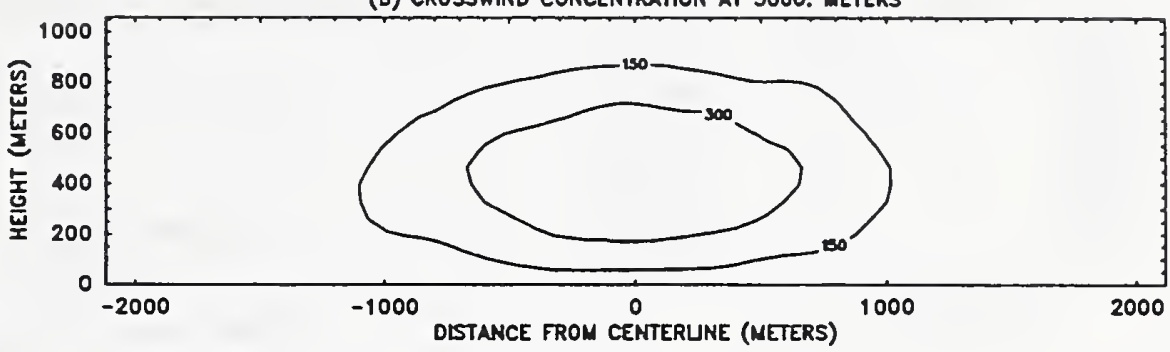

(C) VERTICAL CENTERUNE CONCENTRATION

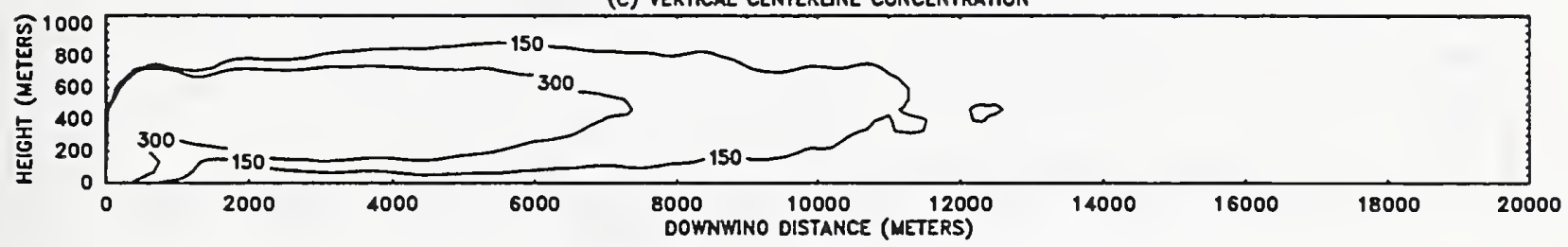

(D) GROUND LEVEL CONCENTRATION

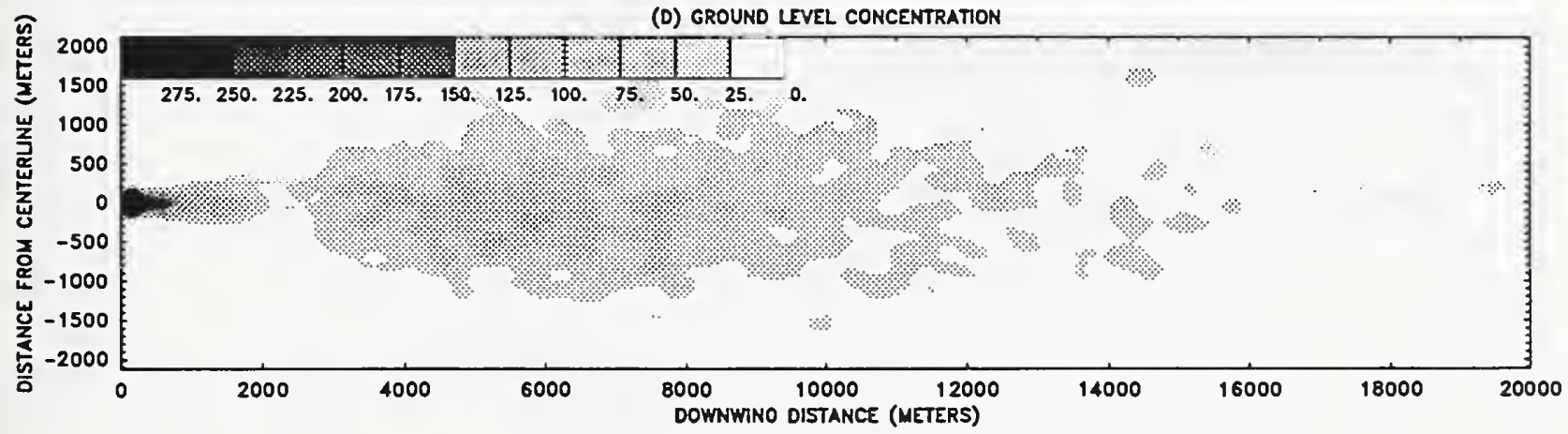

(E) GROUNO CENTERUNE CONCENTRATION

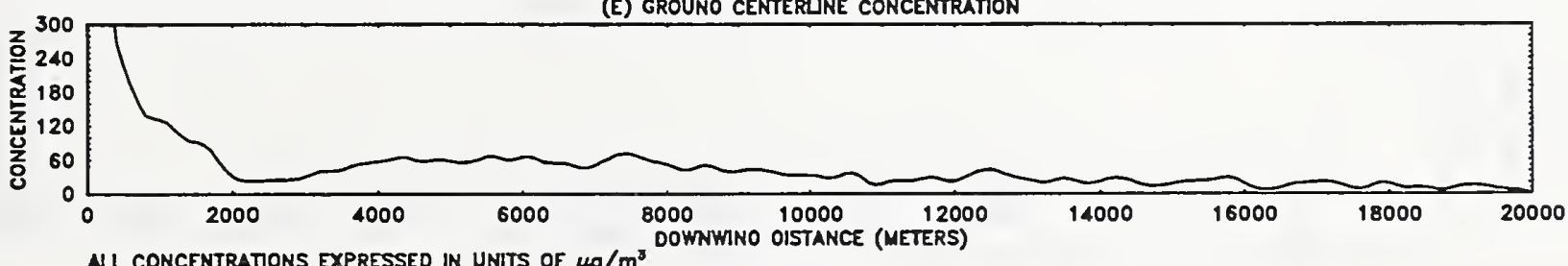

Figure 29 
COOK INLET, WINTER

(A) TEMPERATURE PROFILE

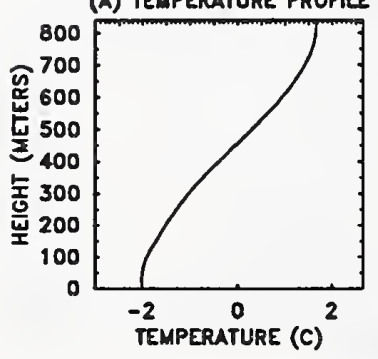

WIND SPEED $8.0 \mathrm{~m} / \mathrm{s}$ STABILITY CLASS D
HEAT LOADING 900. MW MASS LOADING $2.4 \mathrm{~kg} / \mathrm{s}$

(B) CROSSWINO CONCENTRATION AT 5000. METERS

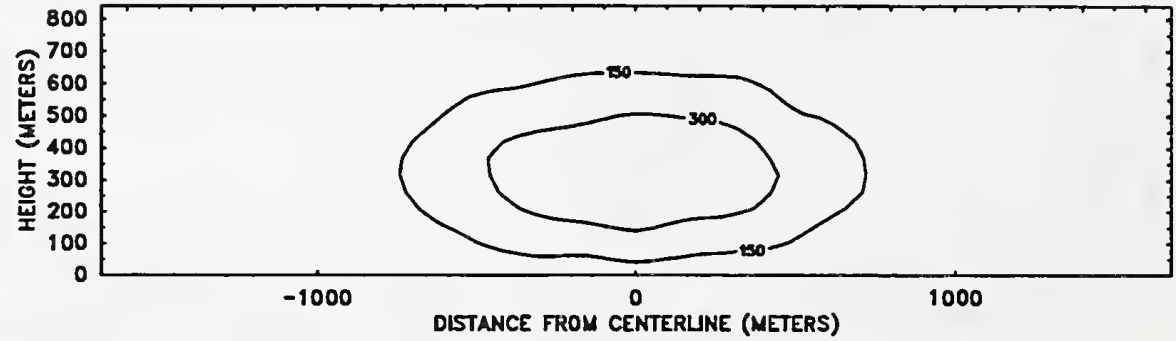

(C) VERTICAL CENTERUNE CONCENTRATION

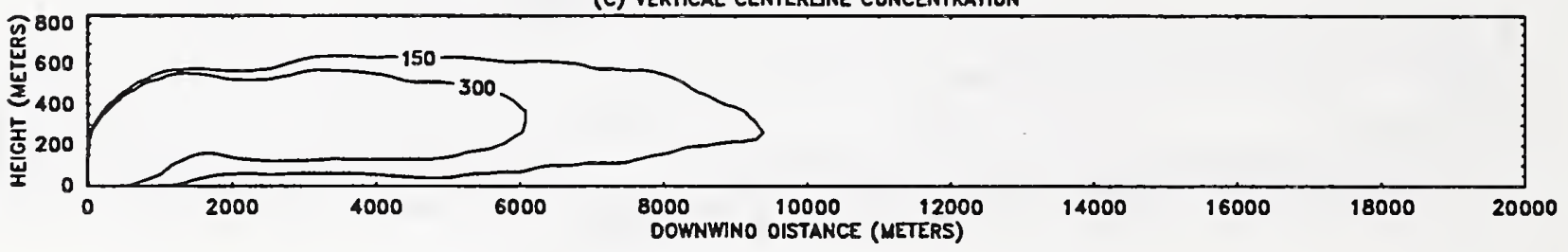

(D) GROUNO LEVEL CONCENTRATION

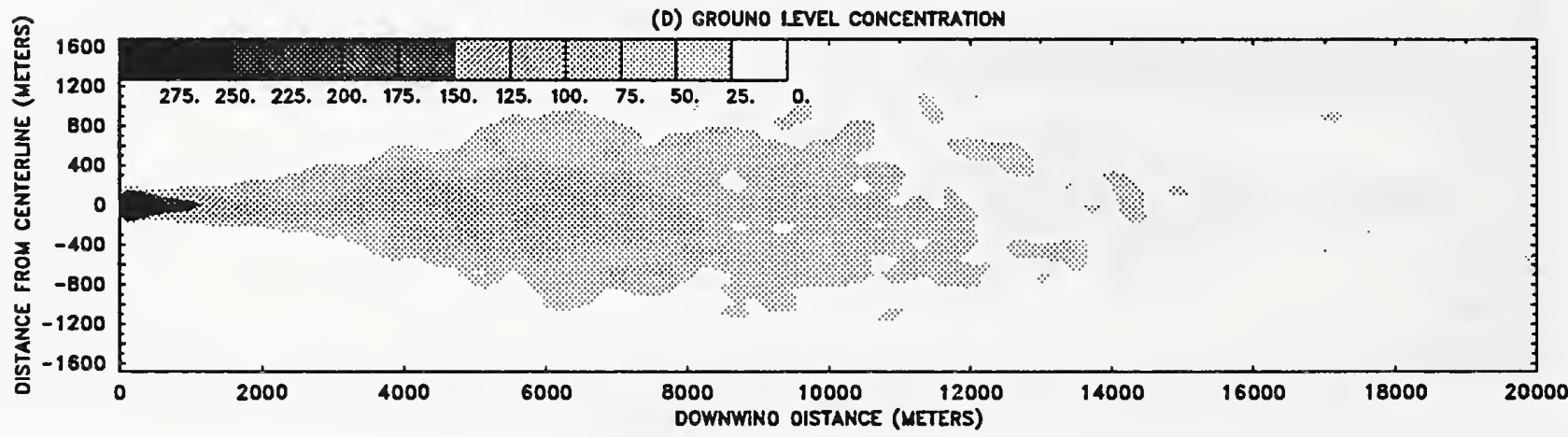

(E) GROUNO CENTERLINE CONCENTRATION



Figure 30 
COOK INLET, WINTER

WIND SPEED $12.0 \mathrm{~m} / \mathrm{s}$

HEAT LOADING 900. MW

STABILITY CLASSS D

MASS LOADING $2.4 \mathrm{~kg} / \mathrm{s}$

(A) TEMPERATURE PROTLL

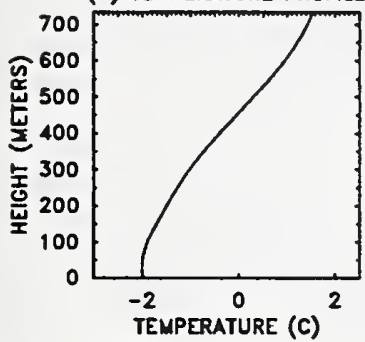

(B) CROSSWINO CONCENTRATION AT 5000. METERS

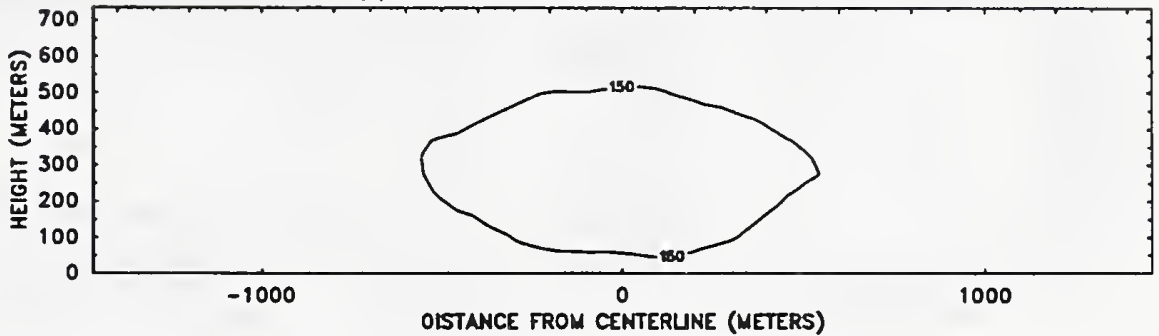

(c) VERTICAL CENTERUNE CONCENTRATION

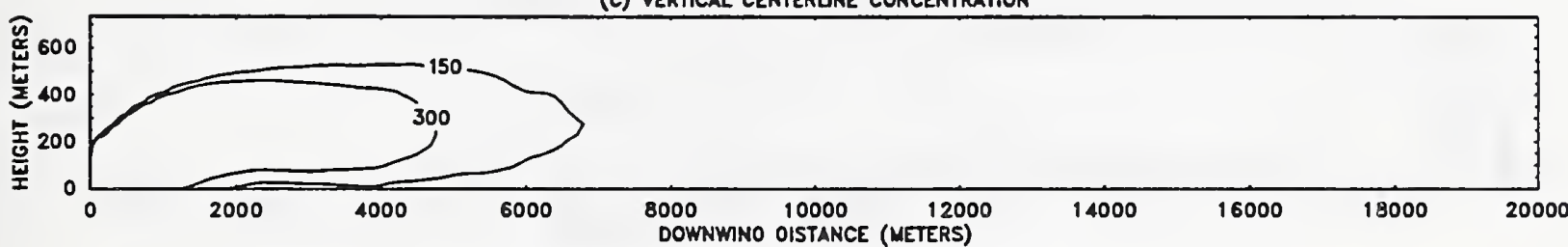

(0) GROUND LEVEL CONCENTRATION

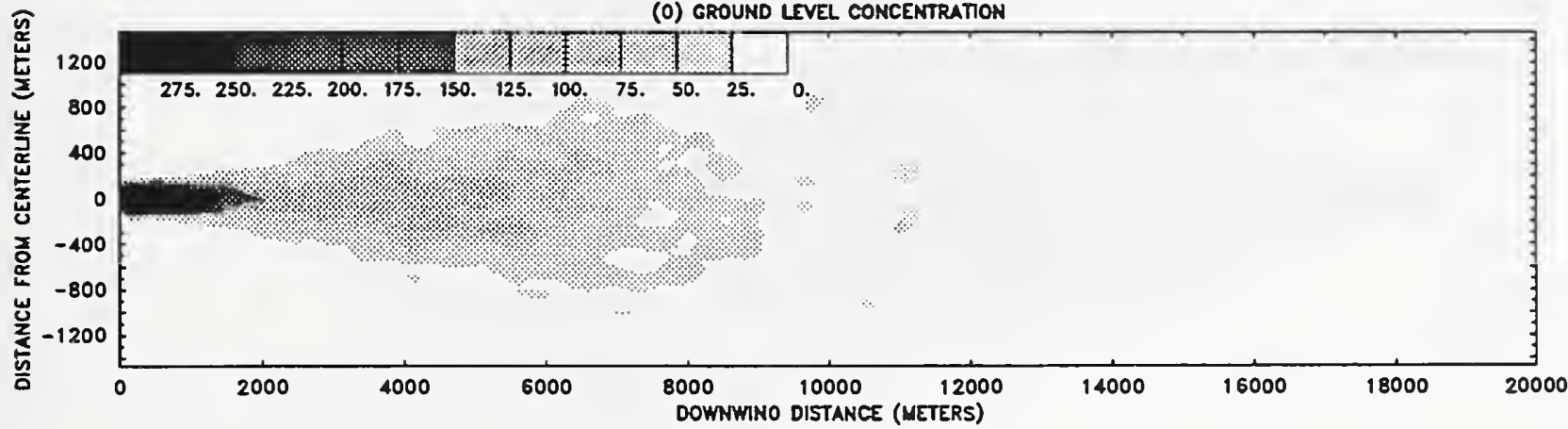

(E) GROUNO CENTERLNE CONCENTRATION



AII CONCENTRATIONS EXPRESSED IN UNITS OF $\mu \mathrm{g} / \mathrm{m}^{3}$

Figure 31 
NORTH SLOPE, SUMMER

(A) TEMPERATURE PROFILE

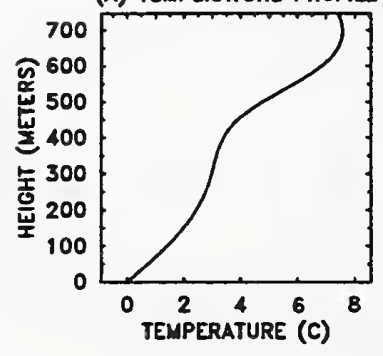

WIND SPEED $4.0 \mathrm{~m} / \mathrm{s}$ STABIUTY CLASS C
HEAT LOADING 820. MW MASS LOADING $2.8 \mathrm{~kg} / \mathrm{s}$

(B) CROSSWINO CONCENTRATON AT 5000. METERS

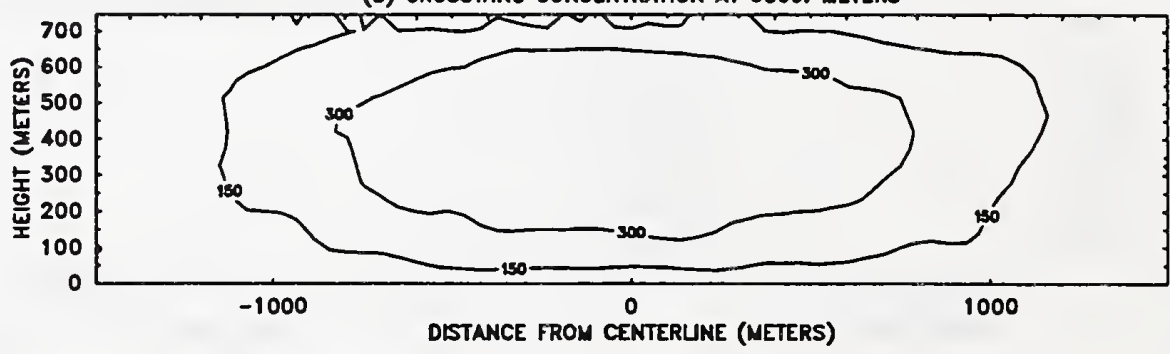

(C) VERTICAL CENTERUNE CONCENTRATION



(0) GROUNO LIVEL CONCENTRATION



(E) GROUNO CENTERLNE CONCENTRATION

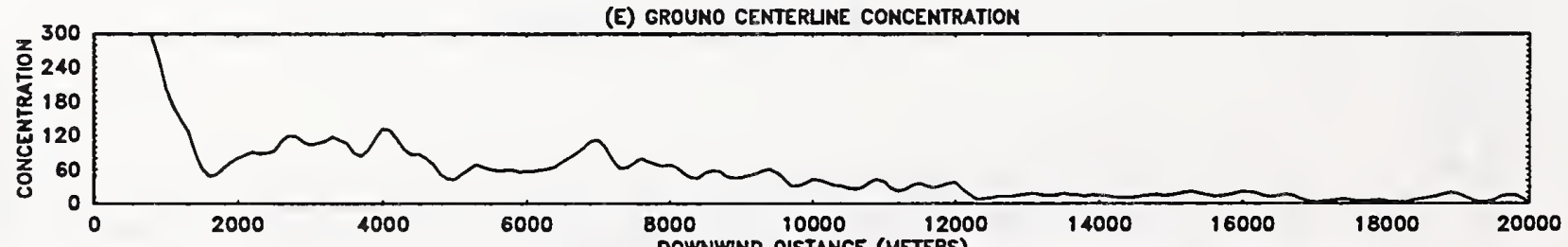

ALL CONCENTRATIONS EXPRESSEO IN UNITS OF $\mu \mathrm{g} / \mathrm{m}^{3}$

Figure 32 

NORTH SLOPE, SUMMER
WIND SPEED $8.0 \mathrm{~m} / \mathrm{s}$
STABIUTY CLASS D
HEAT LOADING 820. MW
MASS LOADING $2.8 \mathrm{~kg} / \mathrm{s}$

(A) TEMPERATURE PROTLE

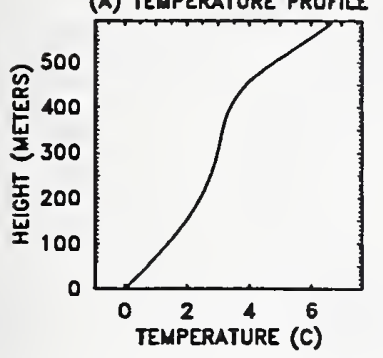

(B) CROSSWIND CONCENTRATION AT 5000. METERS

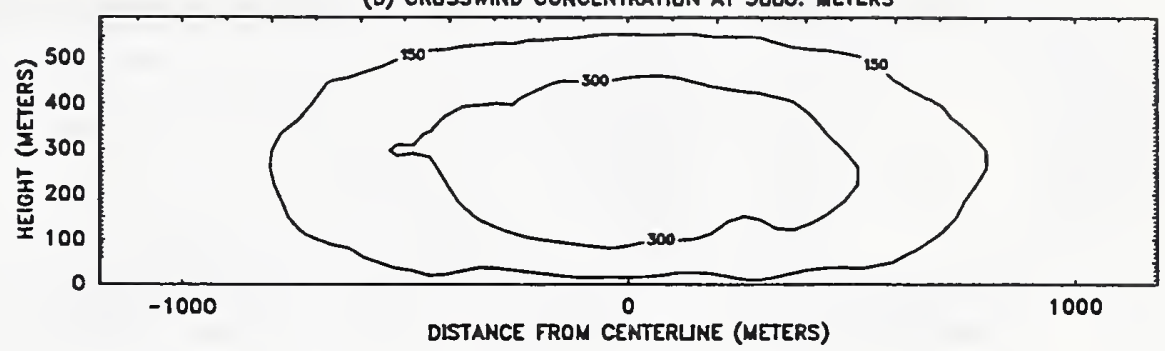

(c) VERTICAL CENTERUNE CONCENTRATION

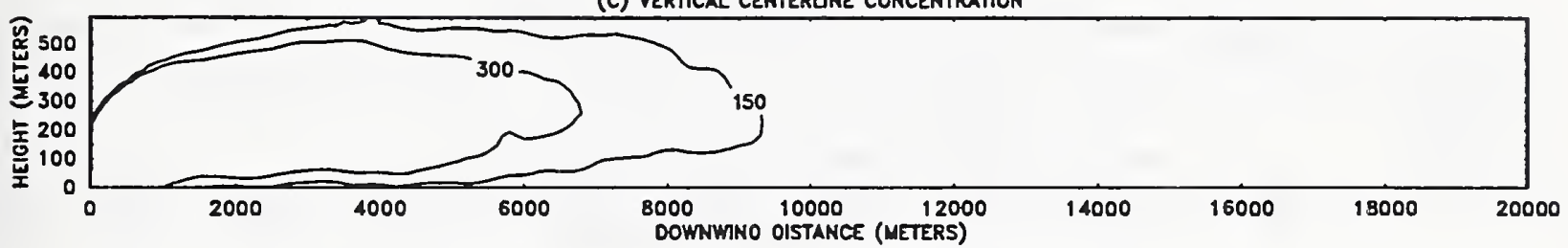

(0) GROUND LEVEL CONCENTRATION

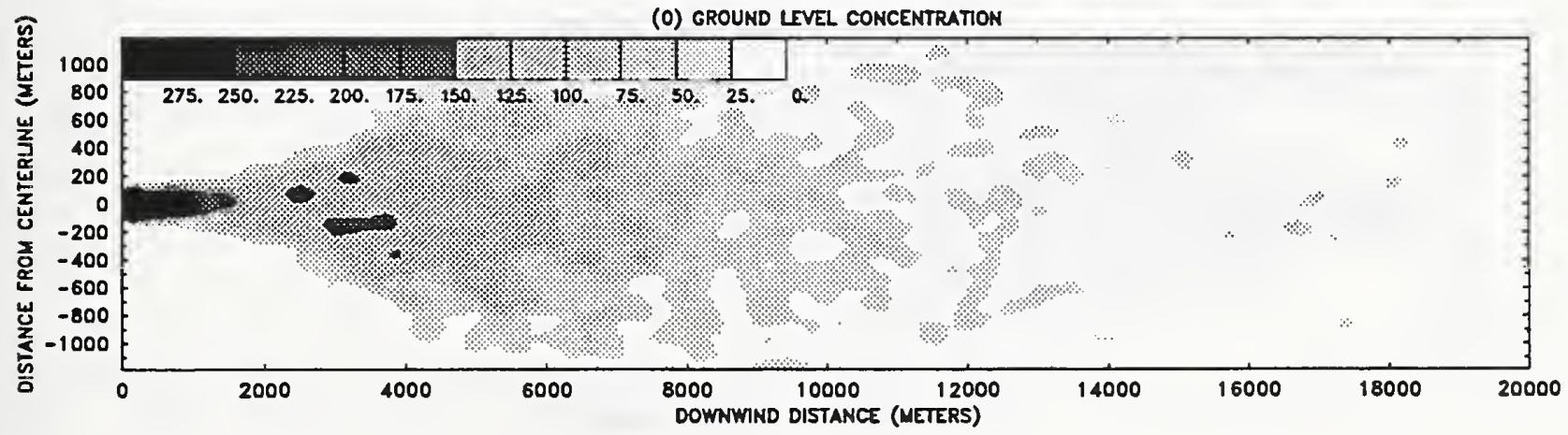

(E) GROUND CENTERUNE CONCENTRATION

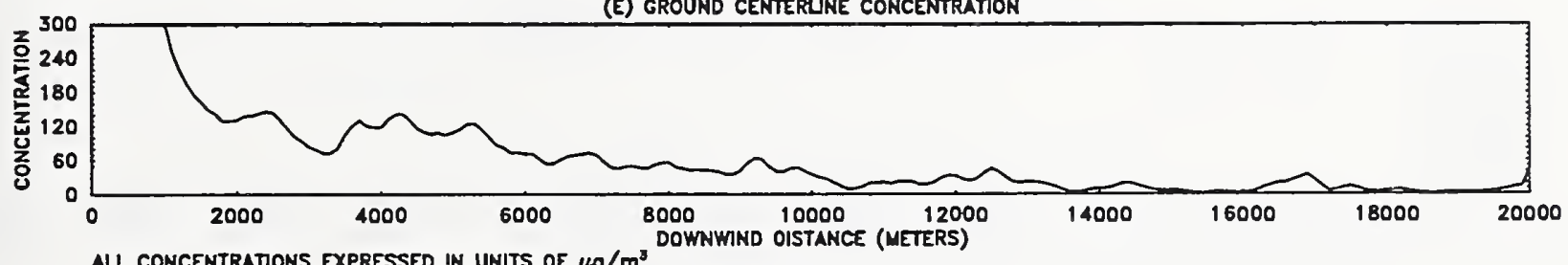

Figure 33 

NORTH SLOPE, SUMMER
WIND SPEED $12.0 \mathrm{~m} / \mathrm{s}$
HEAT LOADING 820. MW STABILITY CLASS D
MASS LOADING $2.8 \mathrm{~kg} / \mathrm{s}$

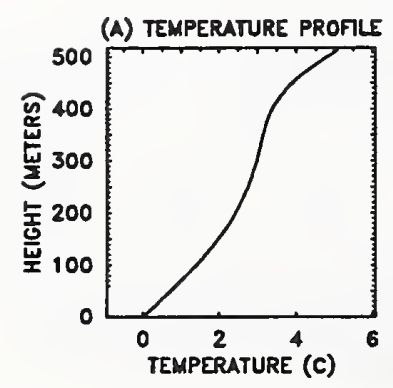

(B) CROSSWIND CONCENTRATION AT 5000. METERS

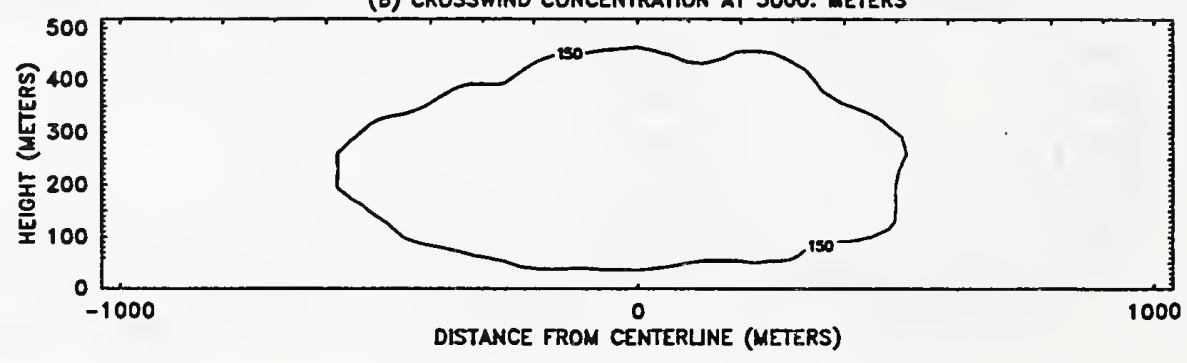

(c) VERTICAL CENTERLINE CONCENTRATION
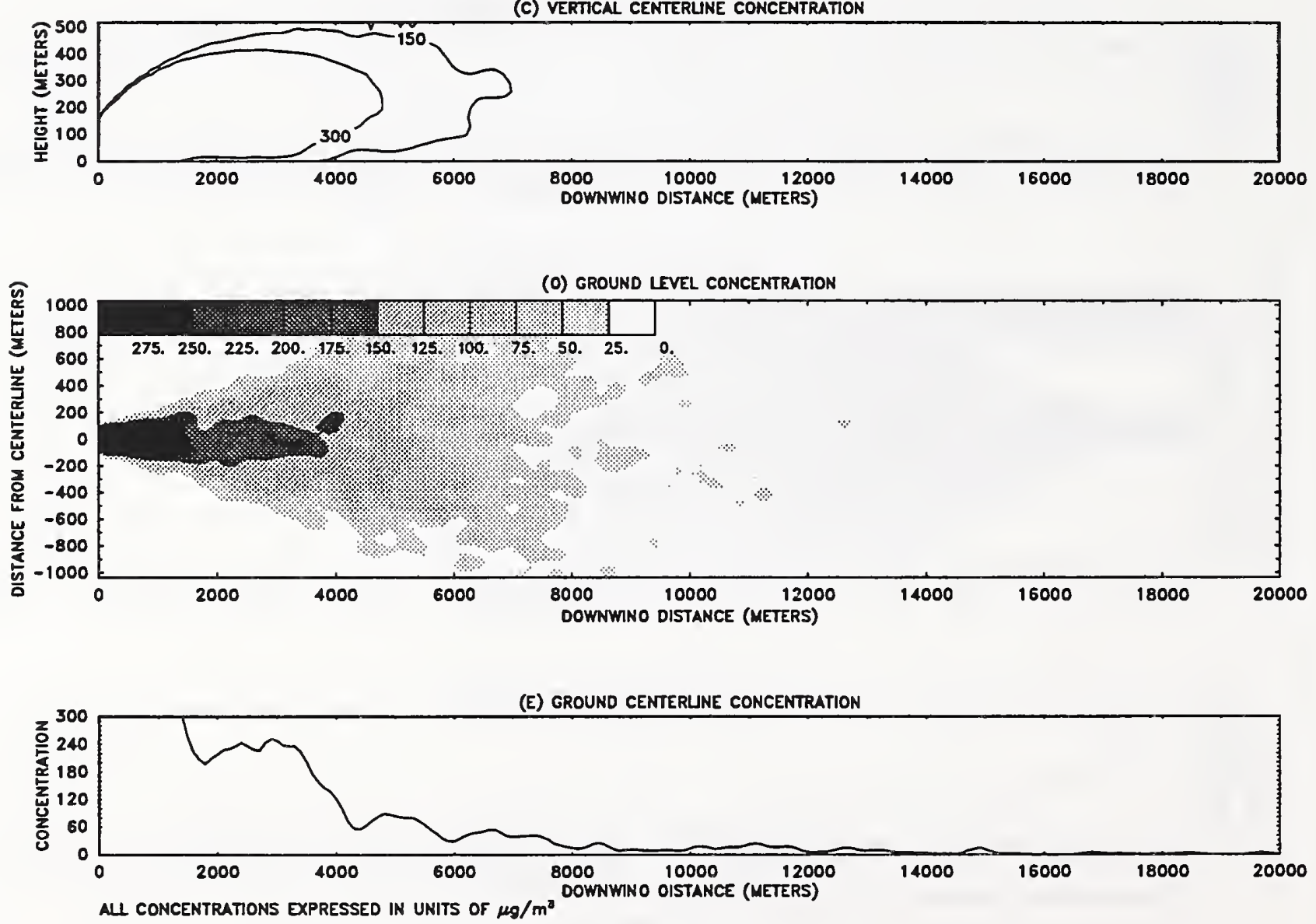

Figure 34 
NORTH SLOPE, WINTER

(A) TEMPERATURE PROFILE
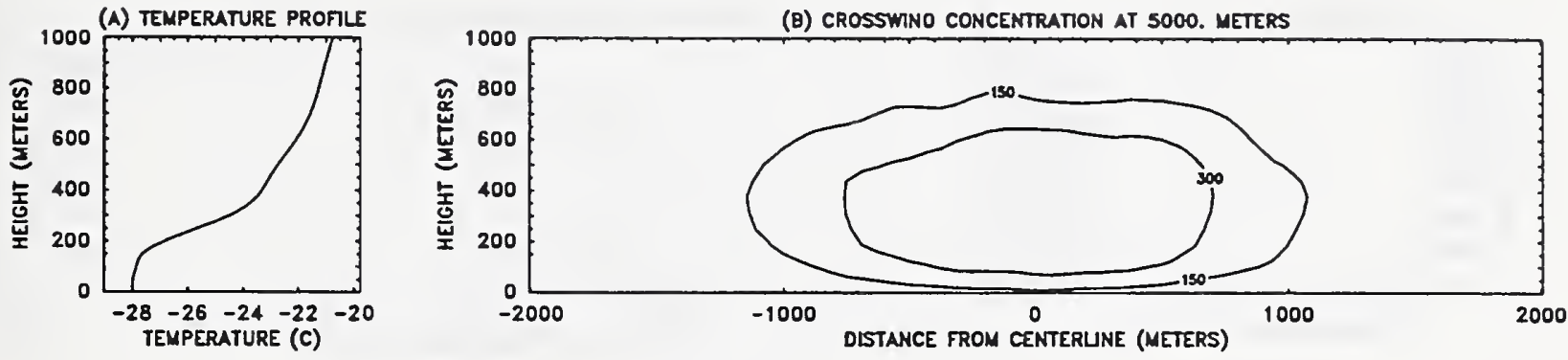

(C) VERTICAL CENTERLINE CONCENTRATION

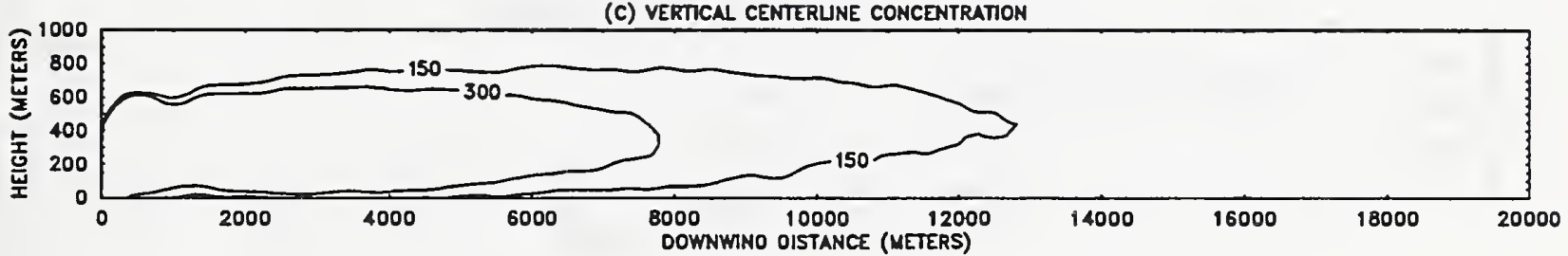

(0) GROUNO LEVEL CONCENTRATION

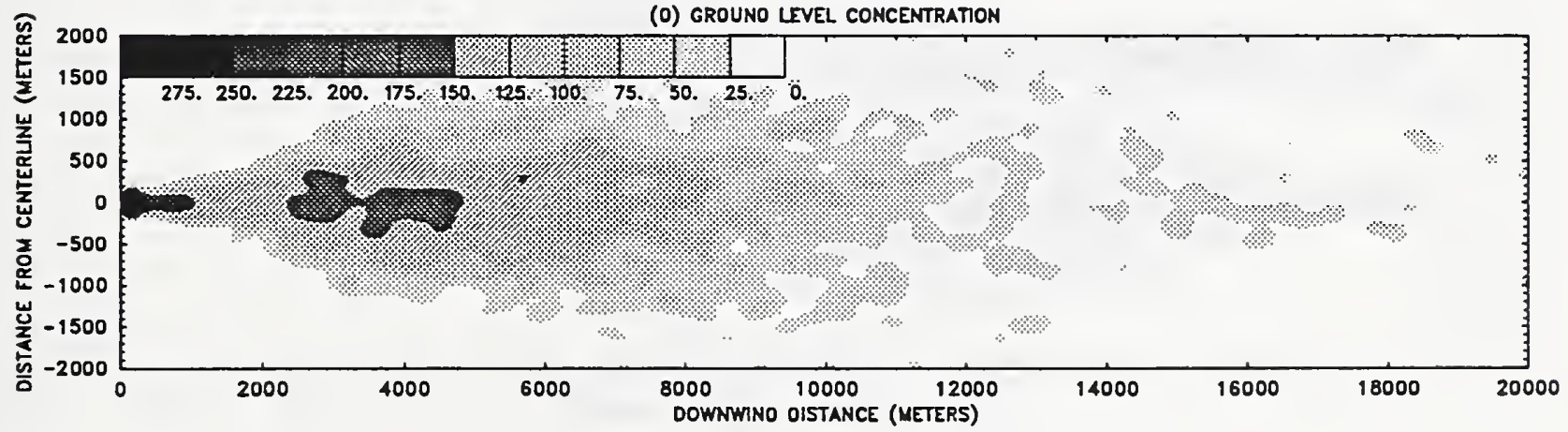

(E) GROUNO CENTERUINE CONCENTRATION

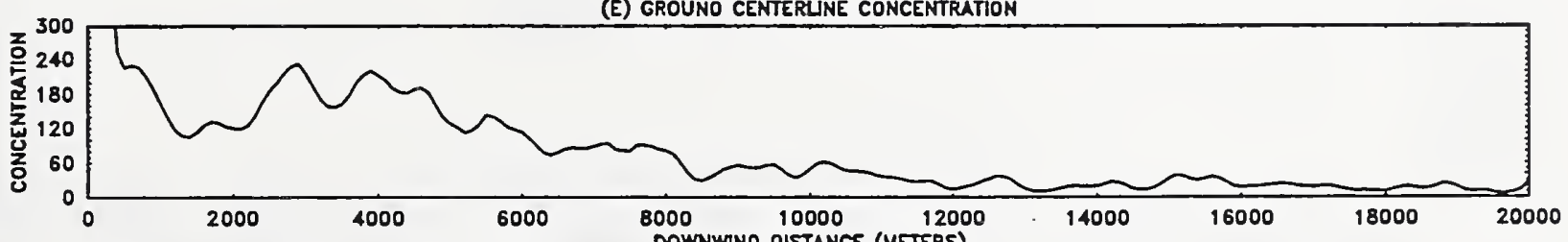

NL CONCENTRATIONS EXPRESSED IN UNITS OF $\mu \mathrm{g} / \mathrm{m}^{3}$

Figure 35 

NORTH SLOPE, WINTER WIND SPEED $8.0 \mathrm{~m} / \mathrm{s}$
STABILTY CLASS D
HEAT LOADING 820. MW

(A) TEMPERATURE PROFILE



(B) CROSSWIND CONCENTRATION AT 5000. METERS

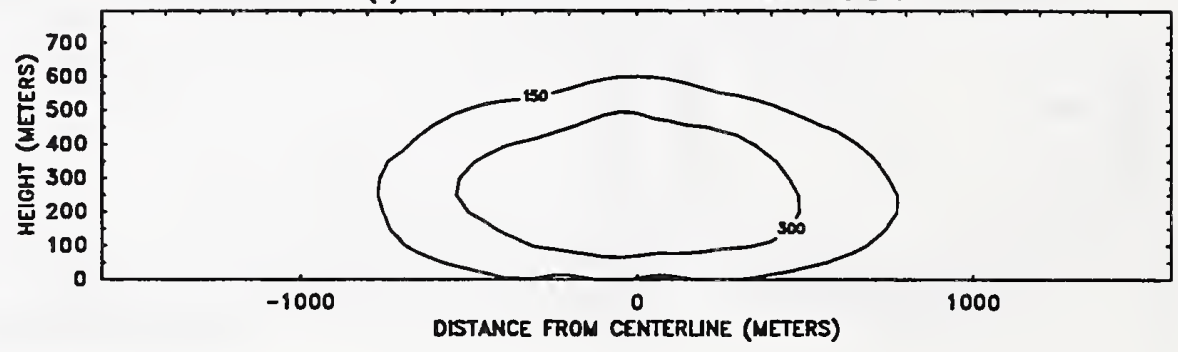

(C) VERTICAL CENTERUNE CONCENTRATION

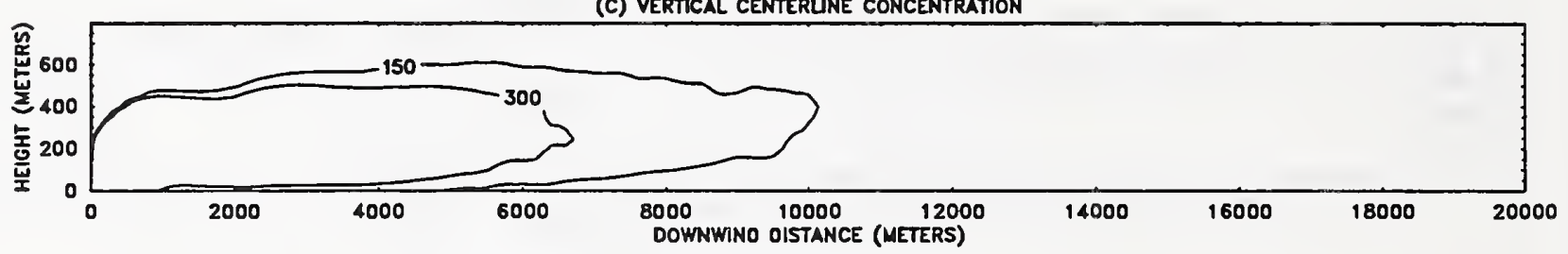

(0) GROUNO LIVEL CONCENTRATION



(E) GROUND CENTERUNE CONCENTRATION

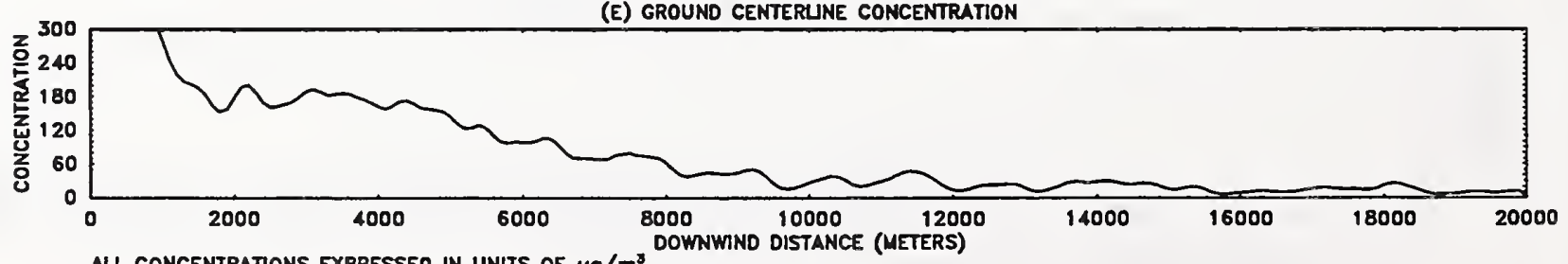

Figure 36 
(A) TEMPERATURE PROTLE



(B) CROSSWIND CONCENTRATON AT 5000. METERS



(C) VERTICAL CENTERUNE CONCENTRATION

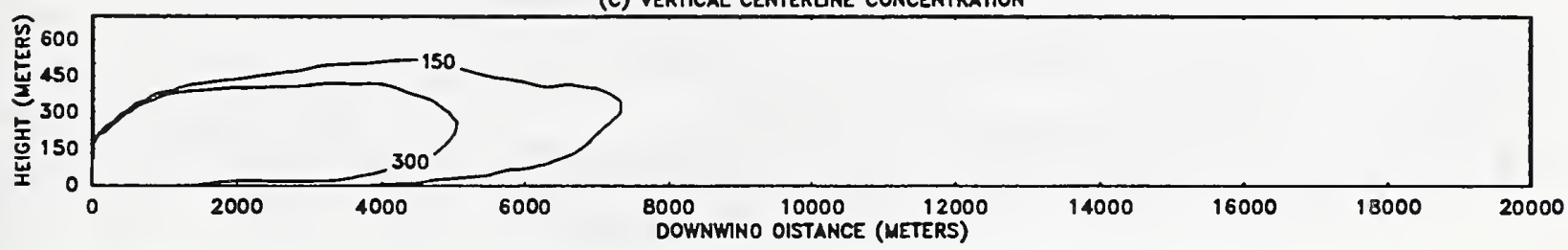

(0) GROUND LEVEL CONCENTRATION

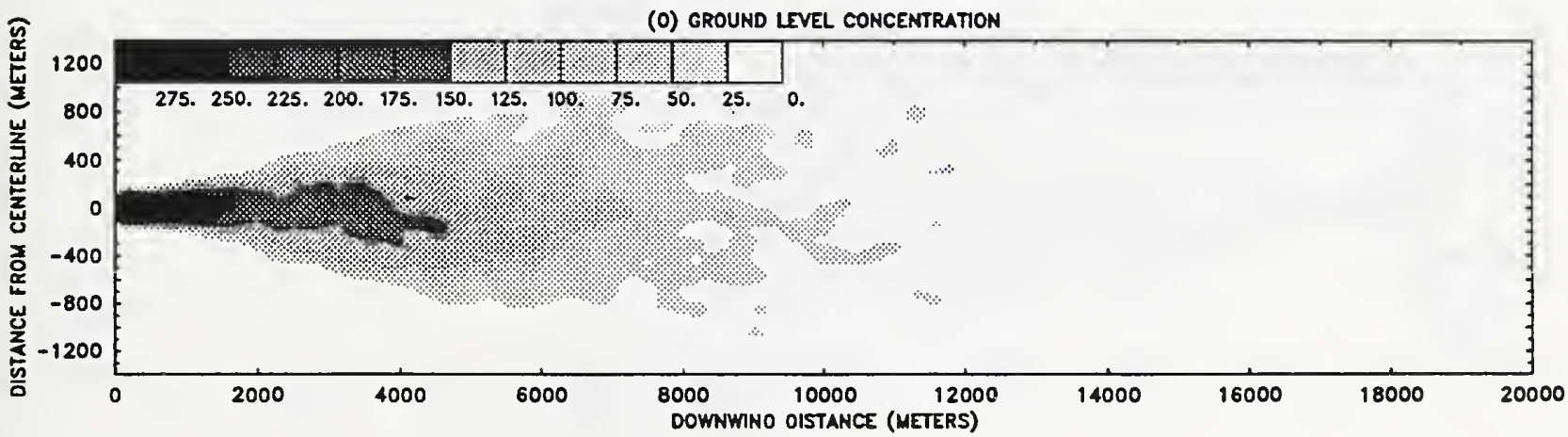

(E) GROUNO CENTERLINE CONCENTRATION

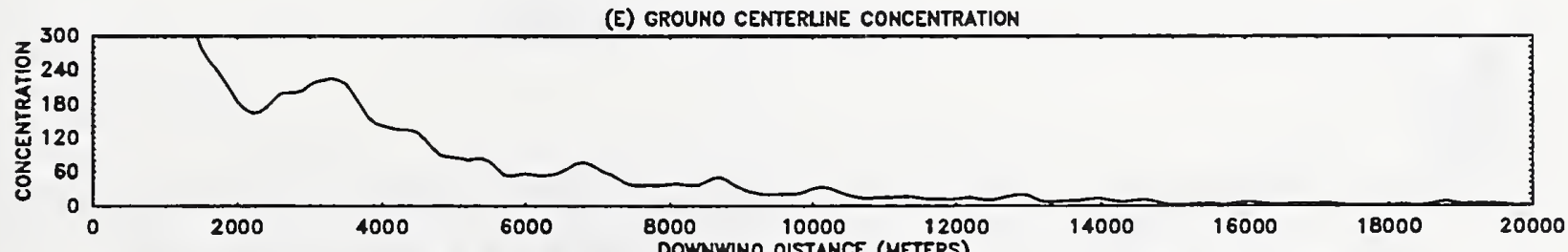

AL CONCENTRATIONS EXPRESSED IN UNITS OF $\mu g / \mathrm{m}^{3}$

Figure 37 
COOK INLET, SUMMER

WIND SPEED $8.0 \mathrm{~m} / \mathrm{s}$ STABILITY CLASS D

HEAT LOADING 1800. MW MASS LOADING $4.8 \mathrm{~kg} / \mathrm{s}$

(A) TEMPERATURE PROFILE

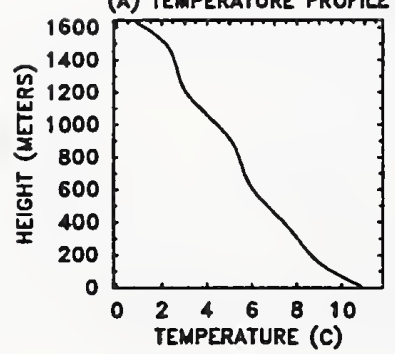

(B) CROSSWIND CONCENTRATION AT 5000. METERS

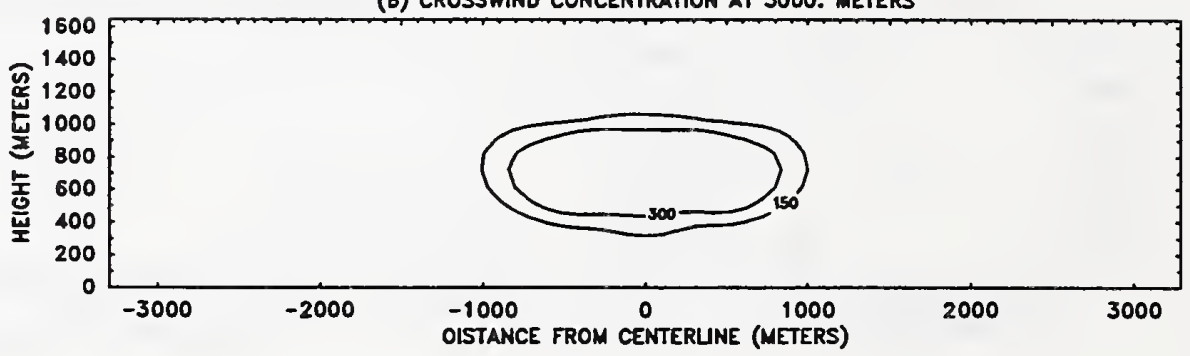

(c) VERTICAL CENTERUNE CONCENTRATION



(D) GROUND LEVEL CONCENTRATION

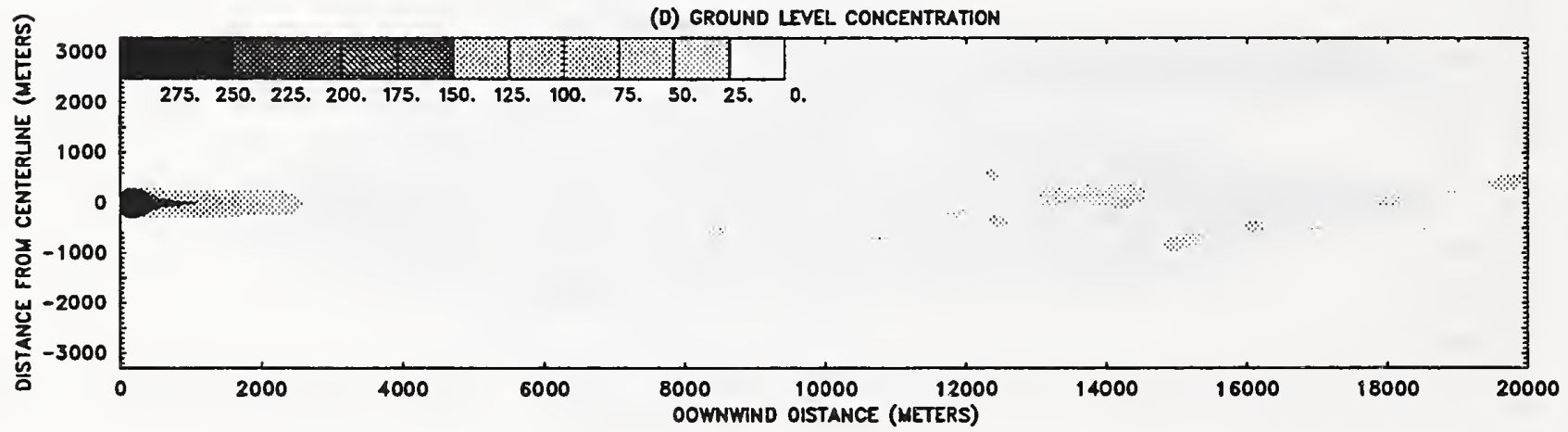

(E) GROUND CENTERLINE CONCENTRATION

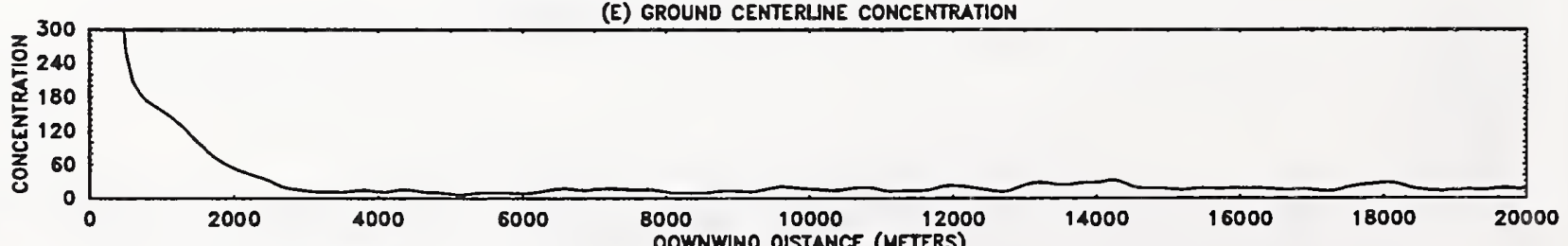

AL CONCENTRATIONS EXPRESSED IN UNITS OF $\mu \mathrm{g} / \mathrm{m}^{3}$

Figure 38 
COOK INLET, WINTER

WIND SPEED $8.0 \mathrm{~m} / \mathrm{s}$

HEAT LOADING 1800. MW STABILITY CLASS D

MASS LOADING $4.8 \mathrm{~kg} / \mathrm{s}$

(A) TEMPERATURE PROTLE

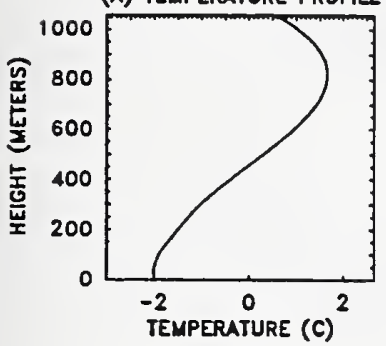

(B) CROSSWINO CONCENTRATION AT 5000. METERS

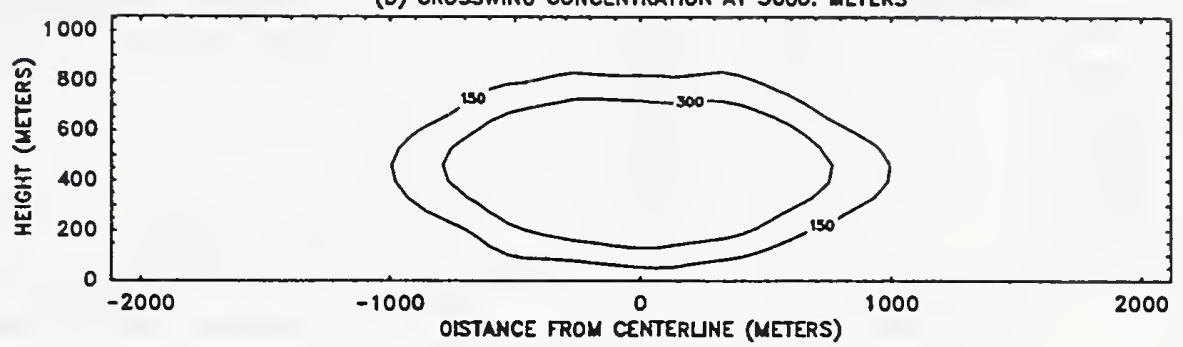

(c) VERTICAL CENTERUNE CONCENTRATION

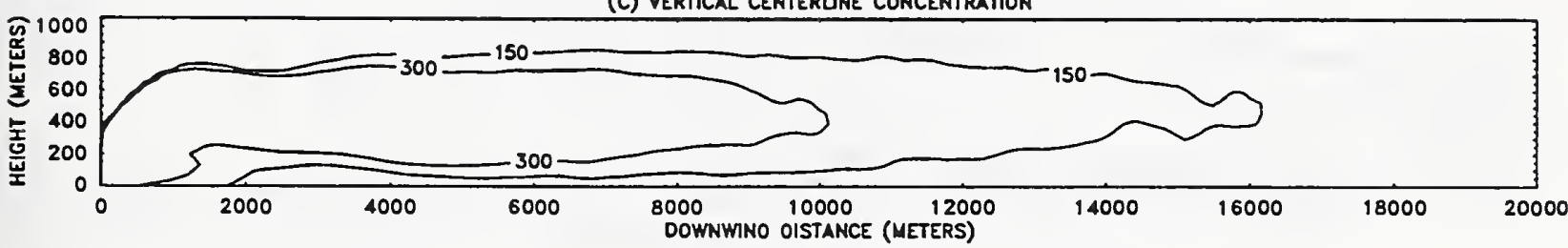

(0) GROUNO LEVEL CONCENTRATION

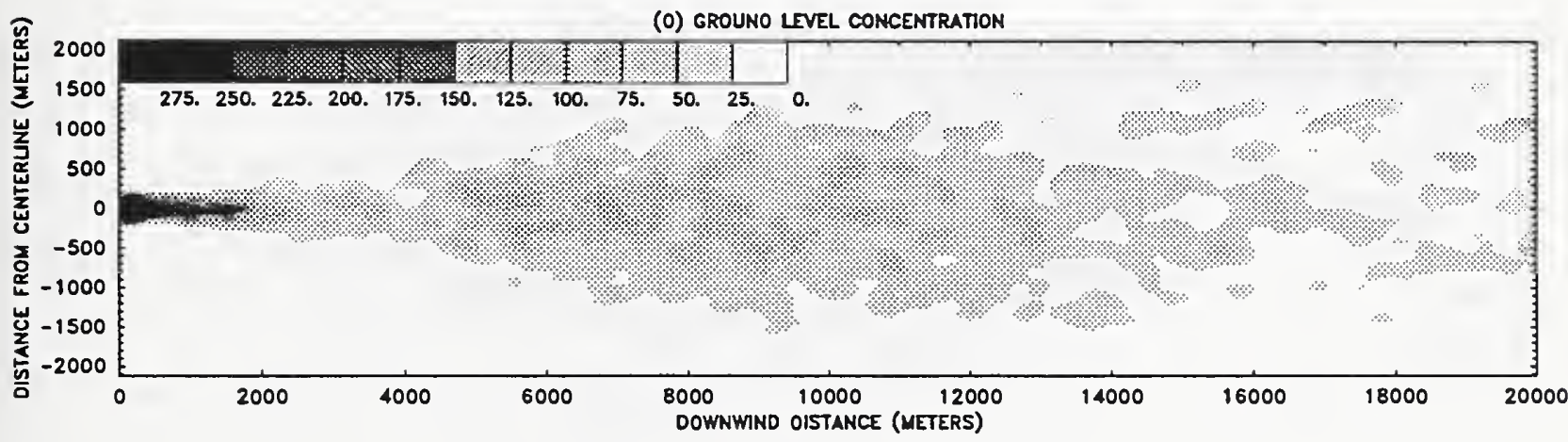

(E) GROUND CENTERUNE CONCENTRATION

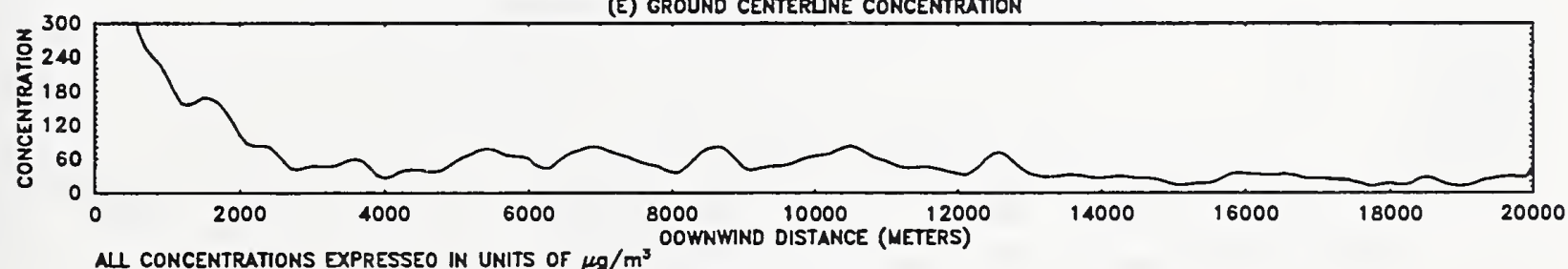

Figure 39 

NORTH SLOPE, SUMMER
WIND SPEED $8.0 \mathrm{~m} / \mathrm{s}$
HEAT LOADING 1640. MW STABILITY CLASS D
MASS LOADING $5.6 \mathrm{~kg} / \mathrm{s}$

(A) TEMPERATURE PROFILE

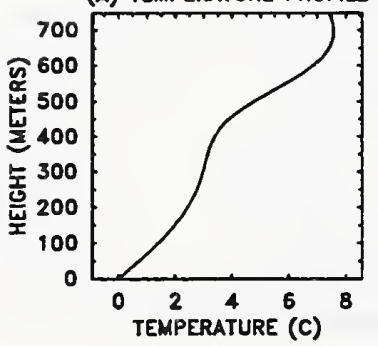

(B) CROSSWINO CONCENTRATION AT 5000. METERS

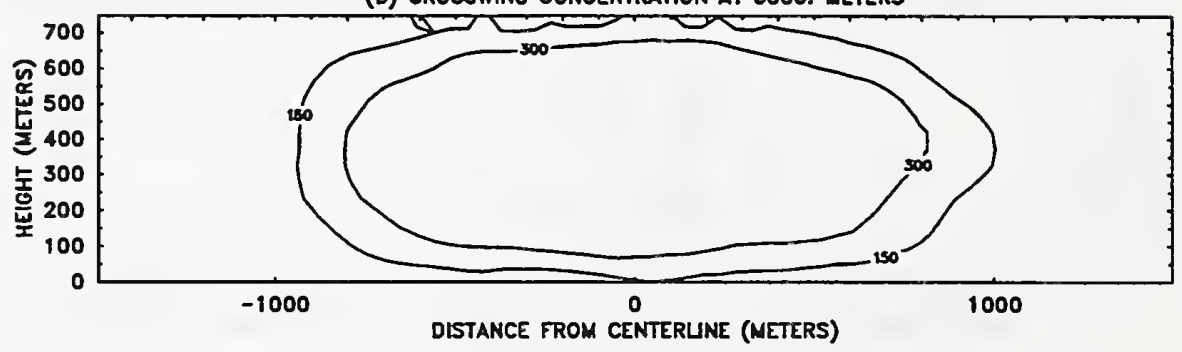

(c) VERTICAL CENTERUNE CONCENTRATION

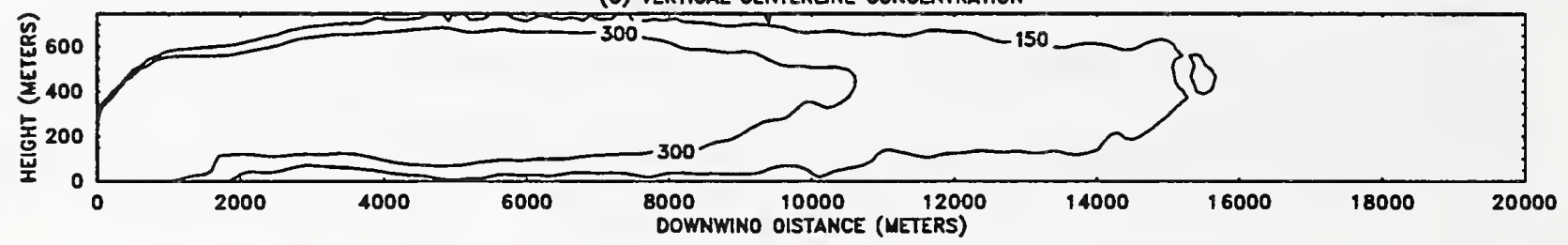

(0) GROUND LFVEL CONCENTRATION

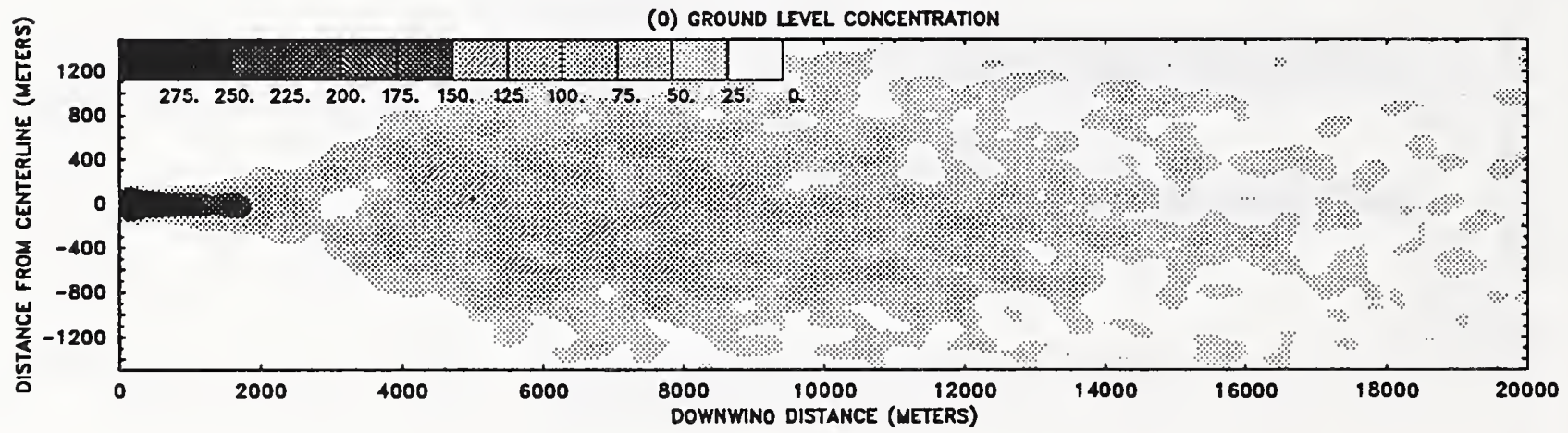

(E) GROUNO CENTERUNE CONCENTRATION

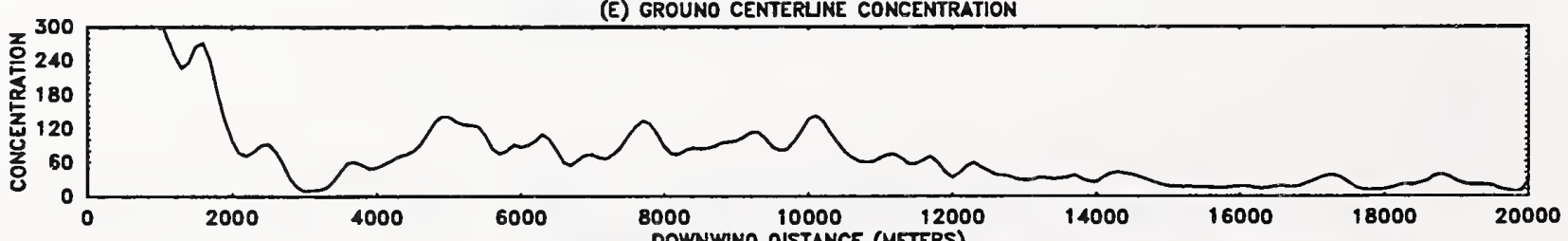

ALL CONCENTRATIONS EXPRESSEO IN UNITS OF $\mu \mathrm{g} / \mathrm{m}^{3}$

Figure 40 
NORTH SLOPE, WINTER

WIND SPEED $8.0 \mathrm{~m} / \mathrm{s}$

HEAT LOADING 1640. MW STABILITY CLASS D MASS LOADING $5.6 \mathrm{~kg} / \mathrm{s}$
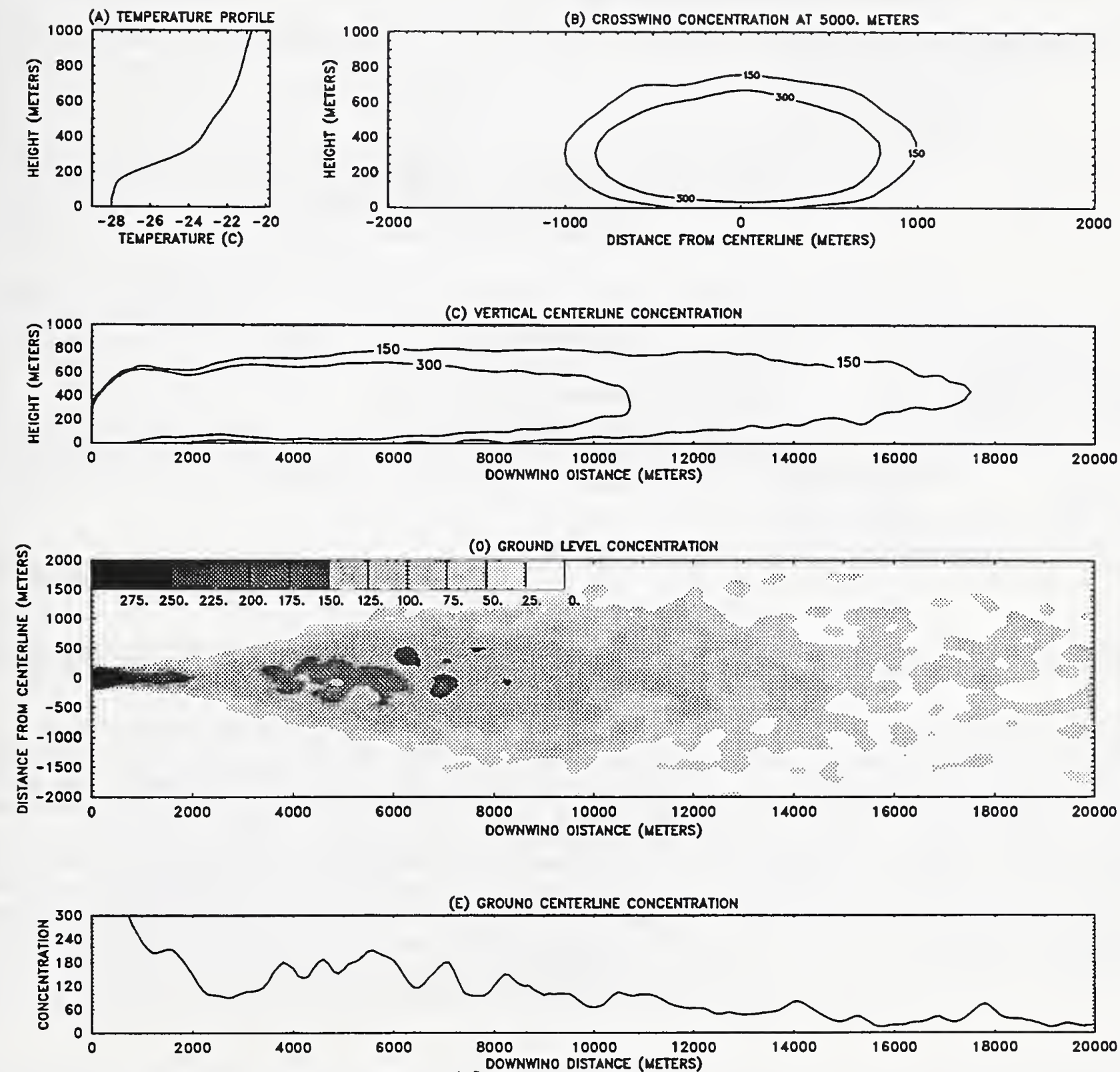
NL CONCENTRATIONS EXPRESSED IN UNITS OF $\mu \mathrm{g} / \mathrm{m}^{\mathrm{s}}$

Figure 41 

NIST-114

(REV. 6-93)

ADMAN 4.09
U.S. DEPARTMENT OF COMMERCE NATIONAL INSTITUTE OF STANDARDS AND TECHNOLOGY

\section{MANUSCRIPT REVIEW AND APPROVAL}

INSTRUCTIONS: ATTACH ORIGINAL OF THIS FORM TO ONE (1) COPY OF MANUSCRIPT AND SEND TO THE SECRETARY, APPROPRIATE EDITORIAL REVIEW BOARD. TITLE AND SUBTITLE (CITE IN FULL)

Smoke Plume Trajectory from In Situ Burning of Crude Oil in Alaska

Building and Fire Research Laboratory, Fire Safety Engineering Division SPONSORING ORGANIZATION NAME ANO COMPLETE ADDRESS (STREET, CITY, STATE, ZIP)

Alaska Dept. of Environmental Conservation (ADEC) 410 Willowby Avenue, Suite 302 Juneau, AK 99801-1795 PROPOSED FOR NIST PUBUCATION

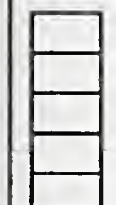
JOURNAL OF RESEARCH (NIST JRES) J. PHYS. \& CHEM. REF. DATA (JPCRD) HANDBOOK (NIST HB) SPECIAL PUBLCATION (MIST SP) TECHNICAL NOTE (NIST TN) PROPOSED FOR NON-NIST PUBLICATION (CITE FULLY)

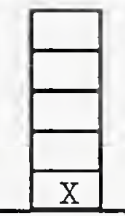
$X$ NIST INTERAGENCY/INTERNAL REPORT (NISTIR)
(ERB USE ONLY

\begin{tabular}{|c|c|}
\hline ERB CONTROL NUMBEA & DIVISION \\
\hline $\begin{array}{c}\text { PUBUCATION AEPOAT NUMBEA } \\
\text { NISTIR } 5273\end{array}$ & CATEOORY CODE \\
\hline $\begin{array}{c}\text { PUBUCATION DATE } \\
\text { OCtOber 1993 }\end{array}$ & MUMBER PRINTED PAGES \\
\hline
\end{tabular}



